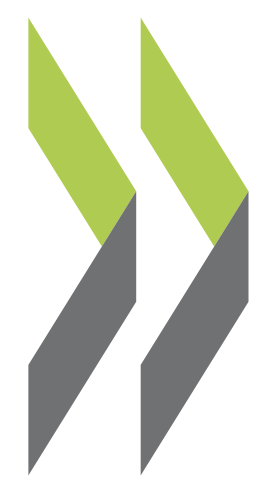

OECD Local Economic and Employment Development (LEED) Papers 2012/20

\title{
Boosting Local Entrepreneurship and Enterprise Creation in Lombardy Region
}

\section{Alessandra Proto,}

Lucia Cusmano,

Neil MacCallum, Ricardo Pinto, Paolo Rosso 


"BOOSTING LOCAL ENTREPRENEURSHIP AND ENTERPRISE

CREATION

IN LOMBARDY REGION"

\section{FINAL REPORT}

A review by the Local Economic and Employment Development (LEED) Programme of the Organisation for Economic Co-operation and Development (OECD)

NOVEMBER 2012 


\section{ABOUT THE OECD}

The OECD is a multi-disciplinary inter-governmental organisation of 34 member countries which engages in its work an increasing number of non-members from all regions of the world. The Organisation's core mission today is to help governments work together towards a stronger, cleaner, fairer global economy. Through its network of 250 specialised committees and working groups, the OECD provides a setting where governments compare policy experiences, seek answers to common problems, identify good practice, and co-ordinate domestic and international policies.

The OECD member countries are: Australia, Austria, Belgium, Canada, Chile, the Czech Republic, Denmark, Estonia, Finland, France, Germany, Greece, Hungary, Iceland, Ireland, Israel, Italy, Japan, Korea, Luxembourg, Mexico, the Netherlands, New Zealand, Norway, Poland, Portugal, the Slovak Republic, Slovenia, Spain, Sweden, Switzerland, Turkey, the United Kingdom and the United States. The European Commission takes part in the work of the OECD. For more information on the OECD, please visit www.oecd.org/about.

\section{ABOUT LEED}

The OECD Programme on Local Economic and Employment Development (LEED) has advised governments and communities since 1982 on how to respond to economic change and tackle complex problems in a fast-changing world. Its mission is to contribute to the creation of more and better quality jobs through more effective policy implementation, innovative practices, stronger capacities and integrated strategies at the local level. LEED draws on a comparative analysis of experience from the five continents in fostering economic growth, employment and inclusion. For more information on the LEED Programme, please visit www.oecd.org/cfe/leed.

This work is published on the responsibility of the Secretary-General of the OECD. The opinions expressed and arguments employed herein do not necessarily reflect the official views of the Organisation or of the governments of its member countries.

This document and any map included herein are without prejudice to the status of or sovereignty over any territory, to the delimitation of international frontiers and boundaries and to the name of any territory, city or area.

\section{(C) OECD 2012}

You can copy, download or print OECD content for your own use, and you can include excerpts from OECD publications, databases and multimedia products in your own documents, presentations, blogs, websites and teaching materials, provided that suitable acknowledgment of OECD as source and copyright owner is given. All requests for public or commercial use and translation rights should be submitted to rights@oecd.org. Requests for permission to photocopy portions of this material for public or commercial use shall be addressed directly to the Copyright Clearance Center (CCC) at info@copyright.com or the Centre français d'exploitation du droit de copie (CFC) contact@ cfcopies.com. 


\section{FOREWORD}

Entrepreneurship and the development of Small and Medium-Sized Enterprises (SMEs) are key drivers of economic growth and job creation. The OECD review series on Boosting Local Entrepreneurship and Enterprise Creation, of which this study is a part, examines the capacity of local economies to support successful new enterprise creation and the growth of small enterprises and make recommendations on how this capacity can be enhanced through local policies.

The reviews entail an assessment of entrepreneurship and SME performance at the local level, the local framework conditions affecting this performance and the policies in place to back entrepreneurship and SME development. The reviews involve a comprehensive examination of conditions and policies including the key domains of skills, financing, regulations, business support infrastructure and innovation.

In the case of Lombardy, the economically most powerful region of Italy, the review includes a specific assessment of local entrepreneurship policies against the framework of the European Union's Small Business Act (SBA). The SBA prioritises the role of business-friendly regulations for the creation of new start-ups and the development of existing small enterprises. SMEs and their clusters constitute the backbone of Lombardy economical structure. In such a context and given the impact of the persisting current financial and economic downturn, supporting the development of innovative SME and their networks is a priority for addressing the recovery challenge.

Against the SBA principles, Lombardy performs well. Within the region, there is a strong foundation of a highly educated workforce, with the presence of many top Italian universities. This provides a valuable knowledge base which is essential for business innovation and growth. Additionally, the report finds that the region has a developed system of SME financing based on mutual guarantee schemes (Confidi). Analysis of this structure reveals a consolidated system that emerging businesses can utilise as a source of growth-funding. In examining the existing regulations and policies of the region, the report proposes areas in which the key findings of the review can be implemented to create further efficiencies within the SBA framework's priorities, in particular by strengthening a more systemic networking base among SMEs and relevant actors based in the region.

The case of Lombardy offers some very interesting lessons for other OECD regions that are seeking to improve their economic performance and increase social inclusion by applying more business-friendly regulations and targeted programmes for SMEs and entrepreneurship. All those regions in Europe seeking to apply the Small Business Act principles at local level will also find inspiration in this report. I would like to thank the Unioncamere Lombardia and the Regione Lombardia for the opportunity they gave us to contribute to this work.

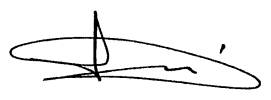

Sergio Arzeni

Director, OECD Centre for Entrepreneurship, SMEs and Local Development

Head, OECD LEED Programme 


\section{AUTHORS AND PROJECT TEAM}

\section{Review manager}

Alessandra Proto, Policy Analyst, OECD

\section{Collection of data through OECD survey}

Unioncamere Lombardia

\section{International review panel}

- Lucia Cusmano, Senior Economist, OECD

- Neil MacCallum, Neil MacCallum Associates, United Kingdom

- Ricardo Pinto, Pinto Consulting GmbH, Germany

- Paolo Rosso, Sign s.r.l., Italy 


\section{AKNOWLEDGMENTS}

This case study of entrepreneurship programmes and the application of the European Union's Small Business Act in the Lombardy region of Italy is part of the series of reviews on Boosting Local Entrepreneurship and Enterprise Creation undertaken by the Local Economic and Employment Development (LEED) Committee of the Organisation for Economic Co-operation and Development (OECD). This work stream is led by Dr. Jonathan Potter, senior economist in the OECD Centre for Entrepreneurship, SMEs and Local Development.

The review was undertaken in collaboration with Unioncamere Lombardia and Regione Lombardia. The work was supervised by Ms. Alessandra Proto of the OECD LEED Programme, who also edited the report.

The OECD is grateful to Regione Lombardia and particularly to Mr. Francesco Baroni, General Manager of the Department of industry, handicraft, building and cooperation of Regione Lombardia and nominated Mr. SME for the region, for his support and interest in this review.

The work would not have been possible without the commitment of all interview partners and the engagement of Mr. Roberto Valente, Manager of Unioncamere Lombardia. Mr. Valente and his colleagues at Unioncamere Lombardia and at Regione Lombardia provided essential assistance in the implementation and analysis of the surveys, in organising the meetings and in providing useful data and statistics. Mr. Valente was fundamental in facilitating the discussions during the study visit as well as coordinating the relationship with the Regione Lombardia.

Additional thanks go to the various stakeholders in Lombardy that took the time to meet with the OECD international expert team during the study visits and provided invaluable insights to this study.

In addition to Ms. Alessandra Proto and Dr. Lucia Cusmano from the OECD Secretariat, the international expert team consisted of the following experts: Mr. Neil McCallum, Dr. Ricardo Pinto, and Mr. Paolo Rosso.

Essential in-house support to organise the study visit and finalise the report was provided by Mr. Roberto Chizzali from the OECD secretariat and by Mr. Andrea Passalacqua, intern at the OECD LEED Trento Centre, who provided very valuable contribution in the analysis of the survey. 


\section{TABLE OF CONTENTS}

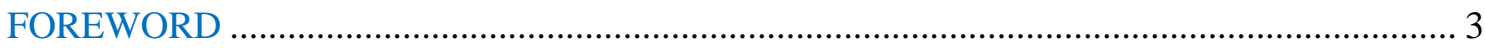

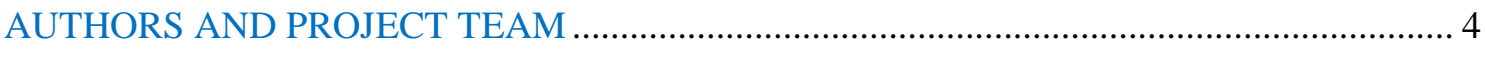

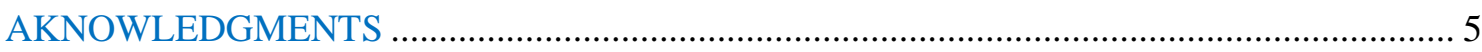

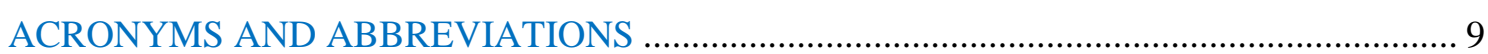

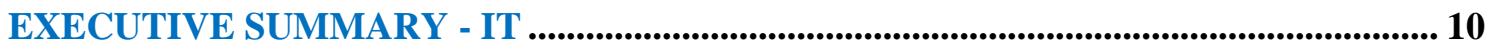

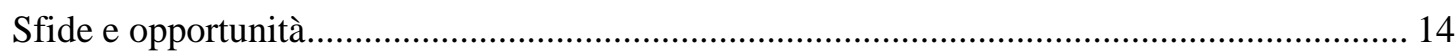

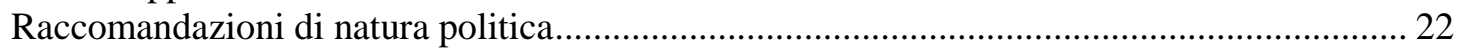

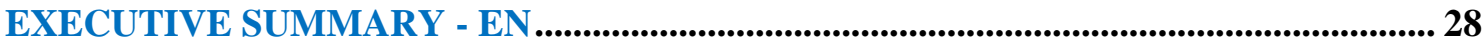

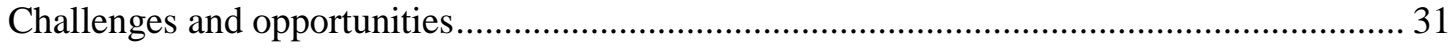

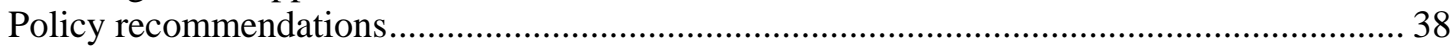

CHAPTER 1: BUSINESS ENVIRONMENT AND SME NETWORKS ............................. 42

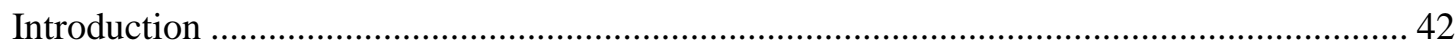

Business environment and SME networks: some findings from research literature .............. 42

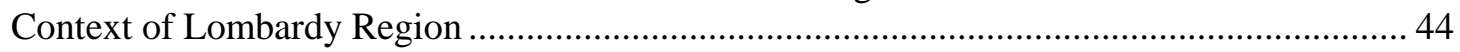

SBA Principles: the importance of business networks, the strengths and linkages .................. 45

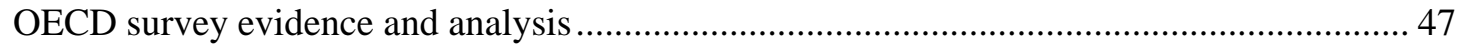

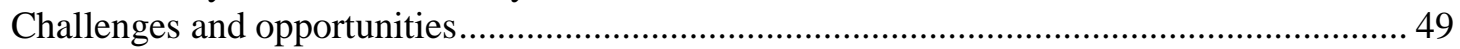

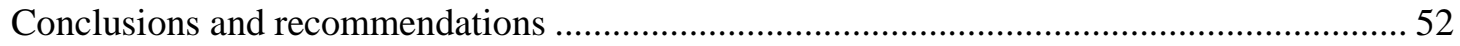

CHAPTER 2: ENTREPRENEURSHIP AND SME WORKFORCE SKILLS................... 57

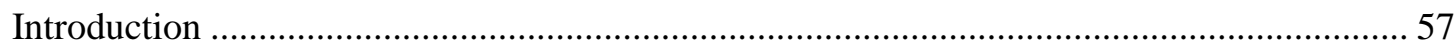

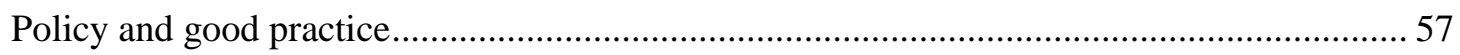

SBA Principles: the importance of entrepreneurship and skills ...................................... 58

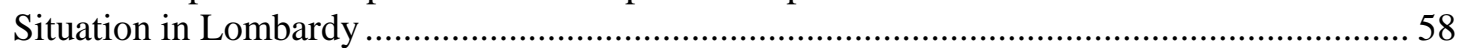

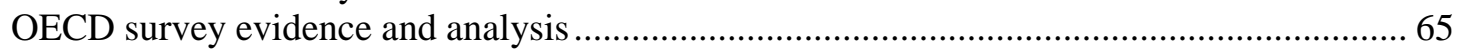

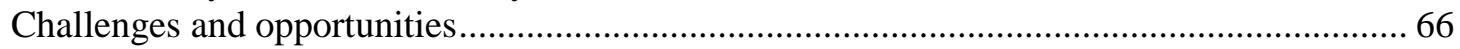

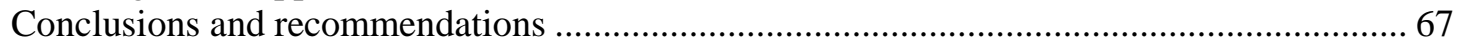

CHAPTER 3: NEW ENTERPRISE CREATION ................................................................ 71

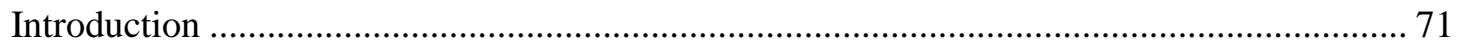

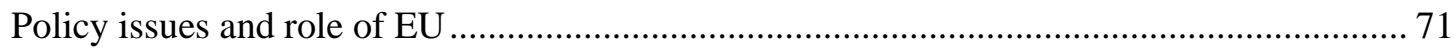

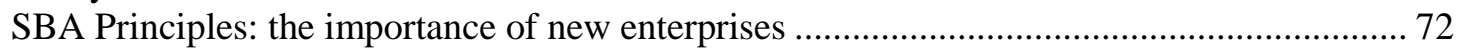

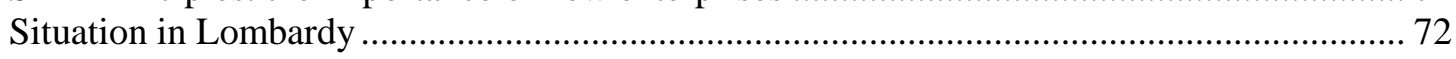

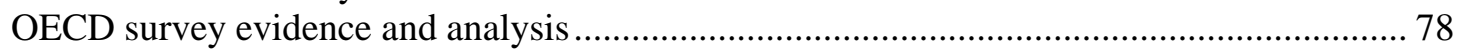

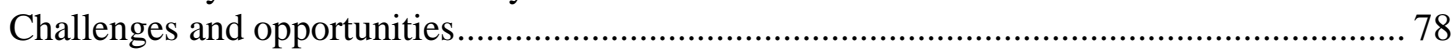

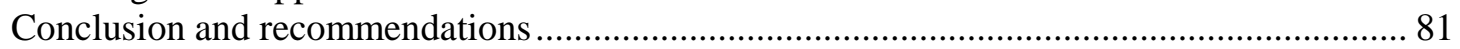


CHAPTER 4: KNOWLEDGE NETWORKS AND INNOVATION ................................. 84

Introduction: importance of knowledge networks and innovation ......................................... 84

Knowledge and innovation drivers for SMEs: some research findings................................ 85

Challenges of knowledge networks and innovation to Lombardy............................................ 86

SBA Principles: knowledge and innovation focus ................................................................. 87

Overview of the innovation system performance in Lombardy Region ................................ 88

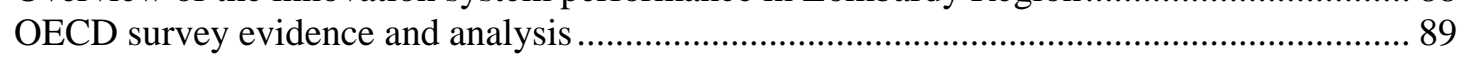

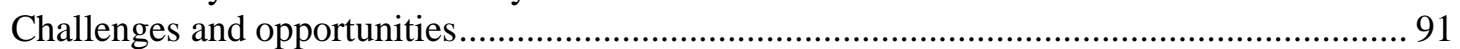

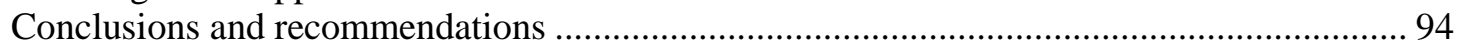

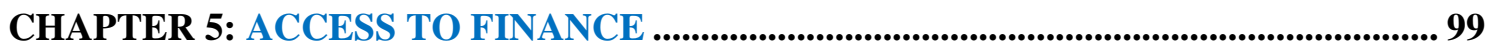

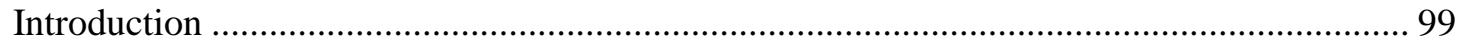

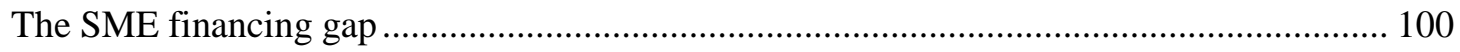

SBA Principles: easing access to finance and developing a supportive framework............... 101

SMEs and entrepreneurship finance in Lombardy ............................................................ 105

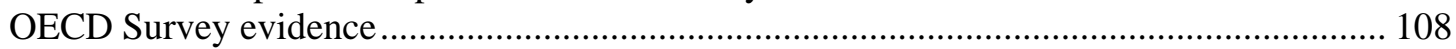

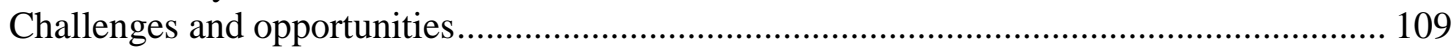

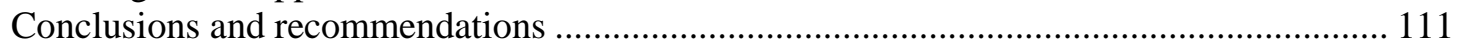

CHAPTER 6: CONCLUSIONS AND POLICY RECOMMENDATIONS.......................... 114

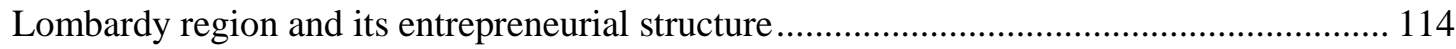

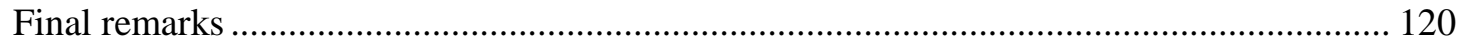

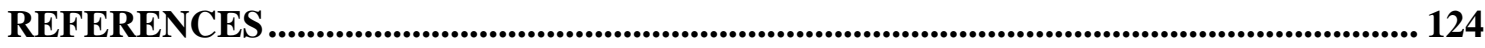

ANNEX I: Learning Models......................................................................................................... 127

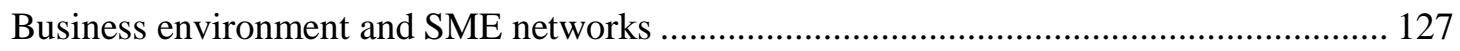

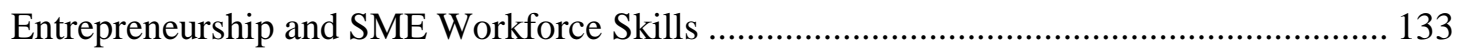

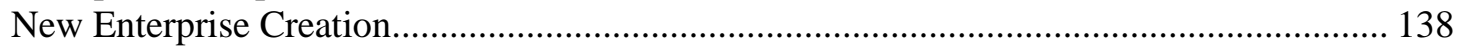

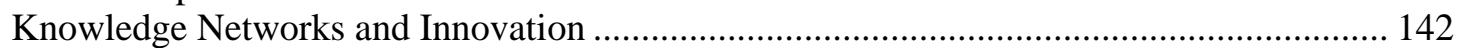

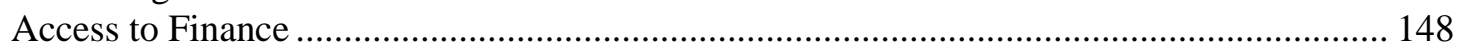

ANNEX II: The OECD Review Team Members.................................................................... 154

\section{Tables}

Table 1. Size of Lombardy Enterprises (1999-2010) ......................................................... 74

\section{Figures}

Figure 1. Contributo (\%) della regione Lombardia alla crescita del PIL (1995-2007)....... 10

Figure 2. Regional contribution (\%) to national GDP growth (1995-2007) ....................... 28

Figure 3. Business Birth and Death Rates in Lombardy (2002-2011).............................. 74

Figure 4. Access to finance: indicators for Italy …………........................................... 102

Figure 5. Lending to firms in Italy (2005-2011)......................................................... 103

Figure 6. Mutual Guarantee Systems (MGS) in Italy (Confidi) ..................................... 104 


\section{Boxes}

Scheda 1. Principali raccomandazioni di natura politica .......................................................... 23

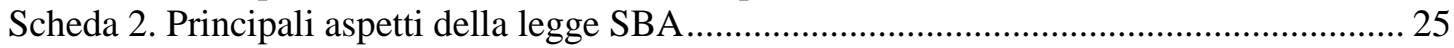

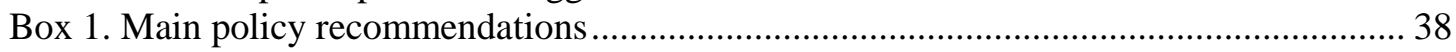

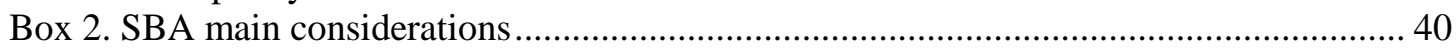

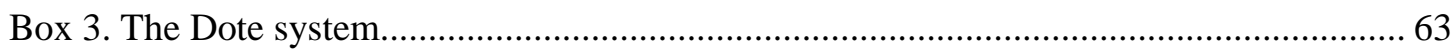

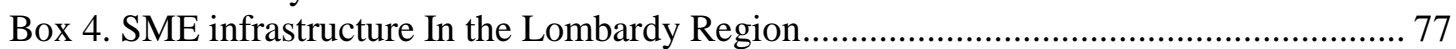

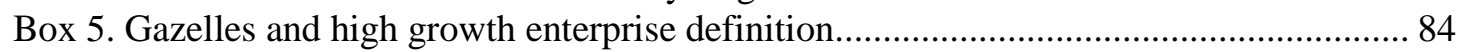

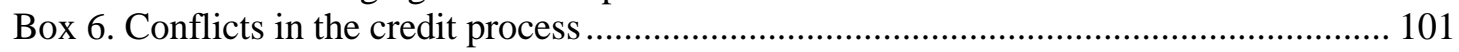

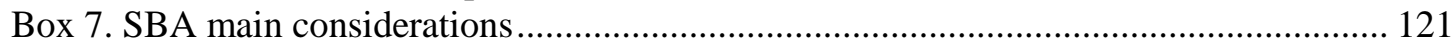




\section{ACRONYMS AND ABBREVIATIONS}

BRIC Brazil, Russia, India and China

EU European Union

GDP Gross domestic product

GEM Global Entrepreneurship Monitor

HEI Higher Education Institution

IP Intellectual property

IReR Istituto Regionale di Ricerca della Lombardia Regional Research Institute of Lombardy

ISCED International Standard Classification of Education,

ISTAT Istituto Nazionale di Statistica (Italian National Institute of Statistics)

LEED Local Economic and Employment Development

M\&A Mergers and Acquisitions

M\&E Monitoring and Evaluation

MNC Multinational corporation

OECD Organisation for Economic Cooperation and Development

PPC Public Private Consultation

R\&D Research and Development

SBA Small Business Act

SME Small and Medium Enterprises

SWOT Strengths, Weaknesses, Opportunities, and Threats

UK United Kingdom

UKIIF UK Innovation Investment Fund

VAT Value Added Tax

VET Vocational Education and Training

VTV Vocational Training Vouchers 


\section{EXECUTIVE SUMMARY - IT}

La Lombardia è una delle principali regioni d'Europa ed è al tempo stesso la regione italiana con la più alta concentrazione di abitanti, di aziende e di ricchezza. Con i suoi 9,8 milioni di abitanti, rappresenta il $15,9 \%$ della popolazione nazionale complessiva e produce circa il $20,6 \%$ del PIL nazionale.

Figure 1. Contributo (\%) della regione Lombardia alla crescita del PIL (1995-2007)

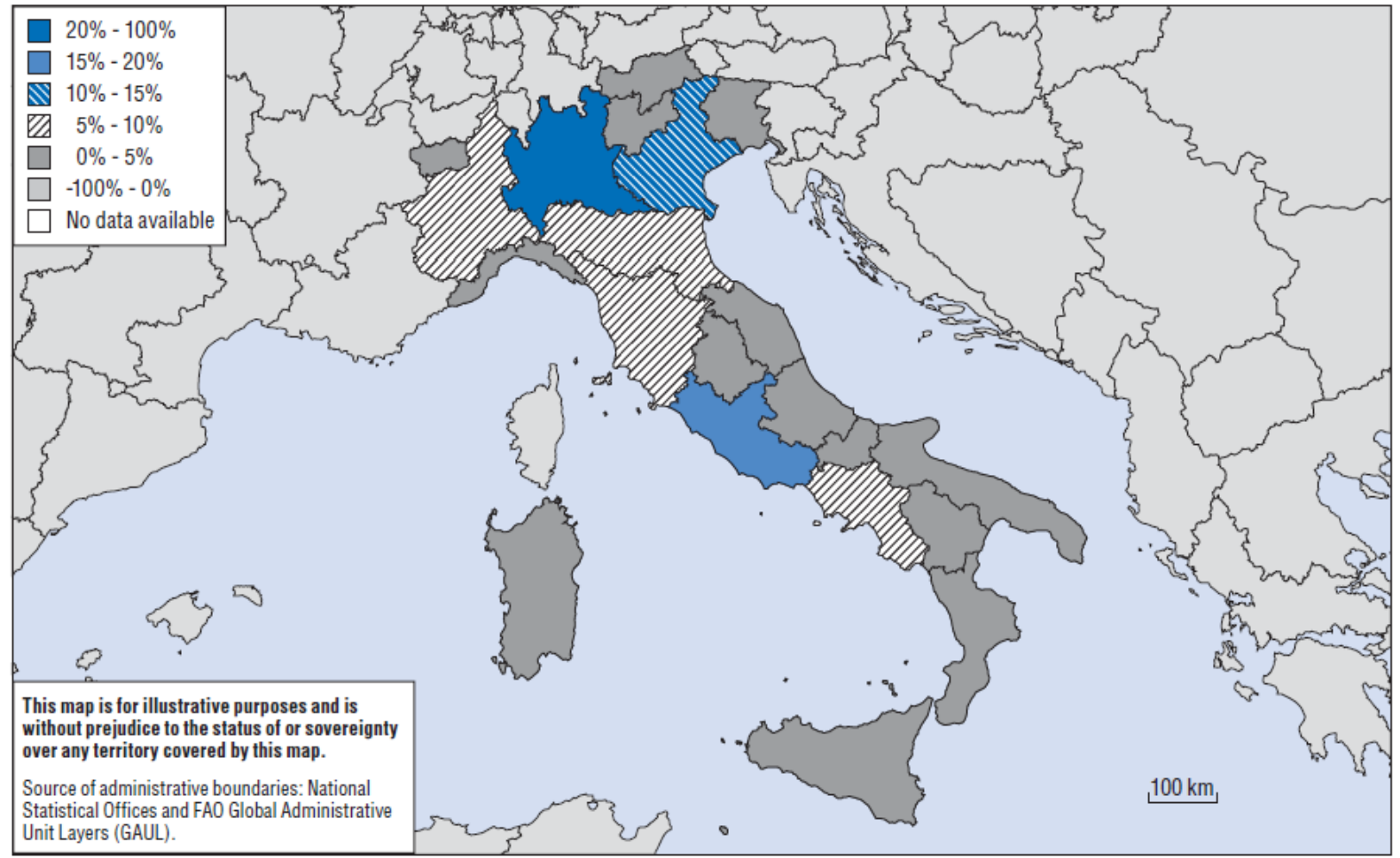

Fonte: OECD Regional Outlook 2011: Building Resilient Regions For Stronger Economies, Calculations based on Cambridge Econometrics and OECD Regional Database (2009).

Una delle principali caratteristiche nell'economia della Regione Lombardia è rappresentata dalla presenza di aziende di piccola dimensione. Nel 2009 erano presenti 823268 società che davano impiego a più di 4,3 milioni di persone. Le piccole e medie imprese costituiscono la colonna vertebrale dell'economia lombarda.

La flessibilità dimostrata in passato dalle piccole imprese e la loro capacità di perseguire un continuo miglioramento dei prodotti costituiscono la principale leva per la loro competitività. L'apertura dei mercati e la competizione su uno scacchiere realmente globale inducono una crescente necessità di competere in nicchie di mercato a maggiore valore aggiunto, con la conseguente necessità di dimostrare capacità di innovazione e di internazionalizzazione. Inoltre, come sottolineato in un recente studio OCSE sull'istruzione superiore nella Regione Lombardia (OCSE, 2011), il sistema economico regionale lombardo sta attraversando un profondo processo di trasformazione della 
struttura industriale verso il settore dei servizi e delle attività terziarie ad elevata specializzazione; tale struttura conserva tuttavia un importante settore manifatturiero, in evoluzione sotto la costante pressione della competizione globale.

Dati del 2010 indicano che la forza lavoro in Lombardia è principalmente assorbita dal settore dei servizi (64\%), mentre il comparto produttivo regionale nel suo complesso continua ad impiegarne una quota superiore alla media del Paese (33,5\% contro il $27 \%)$. Allo stesso tempo, tuttavia, il livello di occupazione nei settori produttivi ad alta e media tecnologia rimane relativamente basso, rispetto alle regioni più avanzate europee, attestandosi sul 10,9\% (da confrontarsi a titolo esemplificativo, con il $21,2 \%$ di Stoccarda o il $12 \%$ del Piemonte).

Al fine di valutare le proprie capacità di sostenere la creazione di nuove imprese e lo sviluppo di piccole e medie imprese (PMI), nell'attuale periodo, caratterizzato da sfide difficili, da una crisi economica globale e dalla crescente disoccupazione nella maggior parte dei paesi OCSE, la Regione Lombardia ha scelto di intraprendere, attraverso il presente lavoro di ricerca, un'analisi di approfondimento specifica. L'analisi intende costituire uno strumento per valutare quali siano gli eventuali margini di miglioramento, connessi all'applicazione dello "Small Business Act (SBA)", documento di indirizzo politico sulle piccole e medie imprese dell'Unione europea e da perseguire anche attraverso l'introduzione di specifiche politiche di sviluppo dell'economia e dell'occupazione su base locale. Lo scopo generale consiste nel contribuire alla creazione di un'economia più imprenditoriale e in grado di offrire migliori opportunità per l'occupazione, per la generazione di posti di lavoro e per una maggiore crescita economica capace di contrastare gli effetti negativi della crisi. Inoltre, si vogliono individuare approcci innovativi alla soluzione dei fabbisogni sociali.

Gli obiettivi chiave del progetto di ricerca, realizzato congiuntamente dal Programma OCSE per lo sviluppo economico e dell'occupazione a livello locale (LEED - Local Economic and Employment Development) e da Unioncamere Lombardia, sono i seguenti:

- Analisi delle condizioni sussistenti in ambito locale per la creazione di nuove imprese e per lo sviluppo delle piccole e medie imprese in regione Lombardia;

- Valutazione delle politiche intraprese in regione per lo sviluppo di una nuova classe imprenditoriale, per la creazione di nuove imprese e per la realizzazione di un contesto favorevole per le PMI;

- Contributo allo sviluppo di politiche regionali attraverso l'individuazione e proposta di opzioni percorribili per superare le barriere attuali e valorizzare nuove potenzialità.

A partire da una prospettiva internazionale, il rapporto vuole fornire indicazioni sulle politiche volte a determinare e rafforzare il contesto di operatività delle piccole e medie imprese in Lombardia, in linea con le linee programmatiche definite dall'Unione europea e contenute nello SBA.

Particolare attenzione viene rivolta alla definizione di un quadro politico coerente, allo sviluppo di strategie efficaci per le PMI e per le imprese in generale, nonché all'applicazione di indirizzi operativi in grado di corrispondere alle istanze di tutti i gruppi di interesse. Le raccomandazioni proposte intendono sottolineare la necessità di un miglioramento dei rapporti tra i soggetti politici, la comunità d'affari, il mondo accademico, i ricercatori e gli operatori, finalizzato allo studio e conseguente sviluppo di politiche efficaci. 
Nella ricerca viene proposta anche una selezione di programmi adottati da altri paesi che possono rappresentare significativi 'learning models', di supporto all'illustrazione e migliore comprensione delle raccomandazioni proposte.

L'approccio metodologico adottato nell'impostazione e conduzione della ricerca si è basato sullo sviluppo di un processo di peer review, condotto dal team di economisti ed esperti internazionali dell'OCSE, e sull'analisi dei risultati di un'indagine diretta condotta, a partire da una struttura predisposta dalla stessa OCSE, su un campione selezionato di rappresentanti istituzionali, categoriali e di operatori locali.

La ricerca si è basata su nove dei dieci principi guida definiti nello SBA:

- P.1. Creare un ambiente in cui gli imprenditori possano prosperare e siano gratificati.

- P.3. Formulare regole secondo il principio "Pensare anzitutto in piccolo".

- P.4. Sensibilizzare le amministrazioni pubbliche alle esigenze delle PMI.

- P.5. Adeguare l'intervento politico pubblico alle esigenze delle PMI.

- P.6. Agevolare l'accesso delle PMI al credito e sviluppo di un contesto economico e giuridico adeguato.

- P.7. Aiutare le PMI a beneficiare maggiormente delle opportunità offerte dal mercato unico e dai mercati dei paesi terzi.

- P.8. Promuovere l'aggiornamento delle competenze nelle PMI e ogni forma di innovazione.

- P.9. Permettere alle PMI di trasformare le sfide ambientali in opportunità.

- P.10. Incoraggiare e sostenere le PMI perché beneficino della crescita dei mercati

La ricerca è stata sviluppata adottando lo schema valutativo e la struttura di criteri specificatamente sviluppati dal programma LEED per la realizzazione di progetti di ricerca che riguardano i seguenti campi d'indagine: "Valutazione dell'attuazione in ambito locale dei principi dello Small Business Act (SBA)" e "Stimolo all'imprenditorialità locale e alla creazione di impresa".

L'impostazione metodologica di riferimento si basa su alcuni aspetti fondamentali che vengono qui sinteticamente rappresentati, evidenziando la modalità con cui si è effettivamente operato nella ricerca, in base alle condizioni specifiche di contesto date in Lombardia:

\section{i. Raccolta e analisi dei dati.}

L'Unioncamere Lombardia ha costituito un gruppo di lavoro locale che ha elaborato e messo a disposizione le informazioni e la documentazione in materia necessarie per lo svolgimento della ricerca. Tale gruppo di lavoro ha affiancato gli esperti OCSE nell'indagine diretta sul campo e nella successiva classificazione delle informazioni e dei dati raccolti. L'OCSE ha provveduto a predisporre una griglia di valutazione e un questionario, che hanno costituito gli strumenti operativi per lo sviluppo dell'indagine e che sono stati completati dai rappresentati politici, istituzionali, delle imprese e dagli operatori locali interessati alla tematica. La griglia di valutazione è stata costruita in base ai principi dello SBA e ai relativi documenti di indirizzo nonché considerando le esperienze, i riferimenti 
derivanti dalle analisi sulle politiche di settore e i documenti di raccomandazione predisposti da Commissione Europea e OCSE. La griglia è strutturata in nove parti, corrispondenti ai citati principi dello SBA. Ciascuna parte comprende un set di indicatori selezionati. Per ciascun indicatore sono stati individuati cinque livelli di riferimento a cui si riconducono le risposte dei rispondenti.

Grazie alla collaborazione di Unioncamere Lombardia, il questionario è stato sottoposto a 90 soggetti, selezionati in base alla loro appartenenza alle seguenti rappresentanze locali:

1. L'amministrazione regionale, responsabile per la definizione delle politiche e per l'attuazione delle linee di azione queste conseguenti, nelle aree di interesse evidenziate dalla ricerca;

2. le organizzazioni governative e non governative che operano sul territorio regionale e la cui missione o funzione principale è connessa con la promozione delle attività d'impresa, lo sviluppo delle PMI, la creazione e attuazione di strategie di sviluppo economico:
a. dipartimenti dell'amministrazione regionale;
b. agenzie di sviluppo, società enti o associazioni operanti sul territorio;
c. enti di promozione e associazioni di categoria;
d. operatori del sistema scolastico e di enti di formazione;
e. reti istituzionali, come le camere di commercio, ecc.

\section{ii. Visita del team di ricerca}

Il gruppo internazionale di ricerca composto da esperti e funzionari OCSE ha effettuato due visite sul campo per la peer review presso la Regione Lombardia, rispettivamente tra l'11 e il 13 aprile e tra il 17 e il 18 maggio del 2012. Nel corso di tali visite il team di esperti ha interpellato i politici locali e regionali e gli altri soggetti coinvolti nello sviluppo del sistema delle imprese e delle PMI raccogliendo i diversi punti di vista sulle materie considerate rilevanti dal gruppo di ricerca. I diversi aspetti della questione sono stati discussi con gli stakeholder, attraverso i quali si è ricostruito il variegato quadro di prospettive riguardanti la regione e le sue PMI, la classe imprenditoriale e le politiche di sviluppo locale.

\section{iii. Rapporto finale}

In base agli esiti della peer review è stato predisposto il presente documento di sintesi finale, strutturato come segue.

Cinque capitoli tematici ciascuno orientato ad approfondire le diverse aree fondamentali di interesse per le politiche politiconi settore:

- Ambiente delle imprese e reti di PMI: esamina le condizioni del contesto regionale e la sua influenza su imprenditoria e PMI.

- Imprenditorialità e professionalità della forza lavoro nelle PMI: esamina le modalità con cui politiche appropriate possano stimolare la costituzione di un contesto di riferimento, all'interno delle istituzioni accademiche, favorevole alla formazione di competenze necessarie per la creazione di imprese, per la formazione professionale e per la formazione continua. 
- Creazione di nuove imprese: approfondisce quali sono i fattori, le condizioni e la loro rispettiva combinazione richiesti per favorire la generazione di nuovi imprenditori e le azioni politiche corrispondenti.

- Reti di conoscenza e innovazione: considera la potenziale importanza ed efficacia che le reti per l'innovazione possono rappresentare nella riduzione delle barriere che ostacolano la collaborazione.

- Accesso a finanziamenti: analizza la mancanza di finanziamenti dedicati alle PMI e la logica di fondo che è sottesa alle politiche in tale area.

$\mathrm{Nel}$ capitolo conclusivo (capitolo 6) vengono rappresentate le conclusioni principali e di ordine generale del lavoro svolto. L'Allegato I contiene la raccolta di 11 esperienze internazionali di programmi che vengono proposte quali "Learning models" $e$ che illustrano le modalità con cui altre regioni hanno reagito a sfide analoghe a quelle che deve affrontare la Regione Lombardia, al fine di costituire un orientamento per il percorso di formulazione di risposte convincenti alle raccomandazioni politiche proposte.

\section{Sfide e opportunità}

\section{Punti di forza}

\section{Produzione economica}

Uno dei punti di forza della Regione è rappresentato dalla sua performance economica. Nonostante la crisi economica generale, la Lombardia rimane una delle regioni più competitive in Europa per produzione/contributo regionale al PIL.

\section{Livello occupazionale elevato tra la}

popolazione maschile

Il livello di disoccupazione è complessivamente contenuto, mentre il livello di occupazione della popolazione maschile si mantiene elevato. Ciò deriva principalmente dall'articolazione della sua struttura industriale e dall'elevato numero di PMI competitive in comparti produttivi per lo più organizzati in distretti industriali. Inoltre, la crescente forza propulsiva e capacità attrattiva di Milano ha capacità di attirare aziende e pendolari da tutta l'Italia settentrionale, specialmente nel settore dei servizi. Va notato comunque come, nonostante l'elevato livello occupazionale, la regione abbia attraversato una fase di stagnazione nella produttività del lavoro risultante da un complesso di fattori che comprendono un livello insufficiente di formazione e qualificazione della forza lavoro, con il conseguente inserimento nel mondo del lavoro di lavoratori con bassa qualificazione.

\section{Tradizione per la qualità e catene di}

subfornitura locali

A livello locale si sono sviluppate solide catene di fornitori, che hanno migliorato la capacità del sistema di generare e mantenere una parte consistente del valore aggiunto. Tra i vari soggetti coinvolti sussiste una dinamica relazionale in cui la conoscenza e le reti rappresentano fattori fondamentali per la creazione di benessere. 
Presenza articolata di organizzazioni di

rappresentanza e promozione delle

imprese

Si è riscontrata la presenza diffusa sul territorio di organizzazioni e di associazioni di categoria, dotate di un'articolata struttura in ambito provinciale e regionale, che collaborano in modo crescente nella promozione di un'ampia gamma di iniziative. Una delle iniziative più significative è lo SBALombardiaLAB, il cui obiettivo è di migliorare il contesto economico di riferimento per lo sviluppo delle PMI e che anima l'attuale dibattito sulle politiche di sostegno. Vari attori intervengono a supporto del sistema imprenditoriale fornendo strumenti finanziari agevolati per l'accrescimento della competitività delle imprese e favorendone alleanze al fine di creare reti e consorzi per la partecipazione a offerte d'appalto congiunte. Queste dinamiche stimolano ulteriormente la creazione di reti di PMI, la collaborazione, lo sviluppo internazionale e l'innovazione.

Elevata qualità dell'istruzione superiore

e del sistema di ricerca

La Lombardia ospita alcune delle migliori università italiane: 15 università e circa 220000 studenti adeguatamente distribuiti su tutto il territorio dimostrano un notevole successo nell'attrarre studenti internazionali, nel finanziamento della ricerca e nella produzione di conoscenza e di pubblicazioni. Il volume della ricerca generata dalle strutture di formazione superiore è importante e la qualità ne è riconosciuta a livello internazionale. La maggioranza delle attività di ricerca e sviluppo in Italia si concentra proprio in Lombardia, mentre la quota di ricerca e sviluppo promossa e sviluppata dalle imprese è la più elevata in Italia dopo il Piemonte. Come risultato, il sistema regionale di innovazione si è andato rafforzando nel corso degli ultimi anni.

Popolazione dinamica con importante

presenza di immigrati

Il livello crescente di diversità, comprendente il grande influsso rappresentato dai migranti presenti nella regione, rappresenta al tempo stesso un punto di forza e una potenziale fonte di imprenditorialità: circa il $25 \%$ della popolazione di migranti censita a livello nazionale è residente in Lombardia. Taluni sono in possesso di un livello di istruzione relativamente alto, altri no. In ogni caso, per propria natura e forma mentale, i rappresentanti della popolazione migrante, spesso di giovane età, tendono ad avere un elevata propensione al rischio e una naturale tendenza all'attività d'impresa. In effetti il dinamismo delle aziende straniere è confermato dai riscontri provenienti dalle associazioni imprenditoriali della Lombardia, anche in un periodo di pesante recessione.

Capitale finanziaria del Paese con

elevata densità di intermediari

finanziari

La regione comprende la città di Milano, riconosciuta città capitale finanziaria di livello europeo e che ospita il maggiore mercato azionario italiano. Il sistema finanziario della regione si contraddistingue per elevata densità di intermediari finanziari, un dato costante nonostante l'importante processo di consolidamento avviato a partire dagli anni ' 90 e ancora in atto. In effetti le banche della regione sono state tra gli attori principali in buona parte delle operazioni di fusione e acquisizione (M\&A) avvenute in Italia in anni recenti, dinamica che ha portato alla creazione dei gruppi bancari di riferimento per il sistema creditizio e finanziario nazionale: Intesa San Paolo e Unicredit. Nel 2008 il 23,5\% degli istituti 
di credito italiani aveva la propria sede legale in Lombardia. Inoltre, la regione ospitava il $79 \%$ delle società finanziarie controllate da banche straniere operanti in Italia (Schena, 2010).

Allo stesso tempo, in regione è presente una quota non marginale $(10,8 \%)$ delle banche di credito cooperativo italiane, le quali concedono credito a tutte le categorie economiche che sono presenti tra $\mathrm{i}$ soci.

Vasta rete di consorzi di garanzia

collettiva dei fidi (Mutual Guarantee

Scheme)

La vasta rete di consorzi di garanzia dei fidi (Confidi) svolge un ruolo fondamentale nel sistema di finanziamento delle PMI in Lombardia. Un'indagine condotta nel 2011 da Unioncamere Lombardia su 31 Confidi regionali ha individuato 238000 aziende associate a questi consorzi. Storicamente, il sistema Confidi è stato caratterizzato da un'elevata frammentazione, con un grande numero di piccole organizzazioni per specifici gruppi di aziende e determinati territori. Tuttavia, nel corso degli ultimi cinque anni il processo di consolidamento che ha caratterizzato l'intero sistema finanziario ha riguardato anche la struttura dei Confidi regionali. Si è avviato un sostanziale processo di aggregazione che ha portato all'emergere di soggetti di medie dimensioni, i quali in taluni casi agiscono anche a livello nazionale. A tutt'oggi i principali attori controllano circa il $76 \%$ del mercato regionale.

Buone prestazioni in termini di

pagamento tempestivo da parte della

pubblica amministrazione

In molti contesti regionali italiani le aziende private incontrano frequentemente difficoltà nell'ottenere pagamenti tempestivi in rapporti con la pubblica amministrazione: la Pubblica Amministrazione provvede sovente alla liquidazione dilazionata dei pagamenti, inducendo la possibilità che le aziende private ne risultino danneggiate. Tale situazione in Italia è piuttosto simile in quasi tutte le regioni con eccezione della Lombardia, in cui la Pubblica Amministrazione ha adottato, con successo, misure vincolanti per la riduzione dei ritardi nei pagamenti limitandoli al massimo a 60 giorni.

\section{Opportunità}

Esistenza di comparti produttivi e

distretti industriali ben radicati e

rinomati

La struttura economica e produttiva della regione è dotata di comparti e settori importanti, con distretti produttivi specializzati ad elevato valore aggiunto. Si tratta di comparti con caratteristiche suscettibili di ulteriore sviluppo grazie all'impulso derivante da un ambiente economico favorevole e dinamico e dalla possibilità di creare ulteriori reti orientate allo scambio di conoscenze. Si ravvisa in particolare l'esistenza di potenzialità specialmente in nicchie specifiche ai margini dei settori maggiormente trainanti che, anche attraverso sinergie intersettoriali, potrebbero rappresentare un'opportunità per le PMI di generare valore aggiunto. In effetti, precedenti ricerche svolte dall'OCSE dimostrano che le reti d'impresa ed i distretti produttivi, favoriscono dinamiche favorevoli alla creazione di imprese, in particolare attraverso lo stimolo alla generazione di nuove "spin-out" nell'ambito dei fondamentali settori di specializzazione principale dei distretti come pure attraverso la creazione di attività 
economiche connesse alla crescita della domanda di servizi indiretti (le cosiddette attività indotte) (OCSE, 2009).

Diversità regionale e le condizioni di

base per la crescita

La presenza e la distribuzione delle industrie in Lombardia è spiccatamente diversificata per quanto concerne i settori manifatturieri e dei servizi, tradizionali e moderni, e la loro presenza sul territorio. Tale sistema articolato potrebbe essere ulteriormente sviluppato e rafforzato attraverso la creazione di reti tra le PMI, facilitando in tal modo l'inserimento in nuovi mercati nei quali si ravvisino positive proiezioni di crescita futura. Esiste un effettivo potenziale per lo sviluppo di nuovi percorsi di crescita sulla base di ciò che gli economisti evolutivi chiamano related variety ("varietà contigua"). Ciò significa che è possibile trasferire molte capacità e innovazioni sia da settore a settore dell'industria, che generando nuove attività ibride, grazie al fatto che nessuna attività è lontana dal punto di vista cognitivo, geografico o strutturale da quelle industriali già esistenti (Potter, J., A. Proto e M. Marchese, 2010).

Istruzione superiore e spin-out generati

dalla ricerca

Il ricco patrimonio di esperienze, idee, conoscenze e reti nel settore dell'istruzione superiore potrebbe essere maggiormente connesso con lo sviluppo delle PMI e venire inoltre promosso mediante incentivi specifici comprendenti sgravi fiscali, voucher e la dotazione di spazi e locali dedicati e condivisi. Come già riportato nella ricerca dell'OCSE specificatamente dedicata alle strutture dell'istruzione superiore, nel corso degli anni 2000 sono stati compiuti molti sforzi per rafforzare i legami tra università e poli di ricerca scientifica nonché per creare agenzie per il trasferimento tecnologico. Si tratta di infrastrutture nuove che hanno portato a risultati positivi: si assiste infatti ad una tendenza alla crescita di brevetti registrati in ambito accademico; il numero di spin-off ricollegati alla ricerca universitaria è cresciuto notevolmente nel tempo, pur partendo da livelli molto bassi all'inizio del decennio. Ad eccezione del Politecnico di Milano, le università sono anche poco attive nel fornire servizi alle aziende. In un tale contesto, la collaborazione tra università si trova in realtà alle fasi iniziali del suo sviluppo in regione.

Le "gazzelle"

Vi sono molti ambiti in cui gli start-up d'impresa e le PMI ad elevato tasso di crescita, potrebbero beneficiare di specifici interventi di assistenza, collaborazioni e nuove iniziative al fine di stimolare processi di sviluppo più rapidi e consentirne l'accesso a reti e risorse importanti. Tali azioni, beneficiando degli apporti provenienti dal settore dell'istruzione superiore, comprendono iniziative volte a colmare divari critici nelle catene di subfornitura e sono connesse alla valorizzazione dei punti di forza dei settori e dei distretti della regione, all'attrazione degli investimenti e allo sviluppo delle reti commerciali.

Imprenditoria femminile

L'OCSE riconosce il valore derivante dall'accresciuta partecipazione dell'imprenditoria femminile quale fattore di crescita sul piano economico e su quello della parità di genere. Il rapporto tra imprese gestite da donne rispetto a quelle gestite da uomini varia da paese e paese, tuttavia le aziende a gestione femminile sono di norma in numero generalmente molto inferiore rispetto a quello delle aziende a gestione maschile. Nei paesi a forte innovazione, gli uomini hanno generalmente il doppio di 
probabilità di essere coinvolti nell'avvio di attività imprenditoriali rispetto alle colleghe donne. In Italia, tuttavia, tra i giovani imprenditori, il rapporto è pari a 2,3 maschi per ogni femmina. Oltre a ciò, tra gli imprenditori affermati si registra un numero ulteriormente inferiore di donne: il rapporto $(2,5$ uomini per ogni donna) è uno dei più bassi tra i paesi GEM (Global Entrepreneurship Monitor) ${ }^{1}$. La Lombardia non costituisce un'eccezione a tale tendenza nazionale e quindi anche un simile aspetto può comportare un'importante potenzialità non ancora valorizzata per la Lombardia e per l'Italia in generale.

Consapevolezza crescente nelle PMI

dell'importanza di investire in istruzione

e formazione

Nonostante siano spesso di piccolissime dimensioni e a conduzione individuale o familiare, in Lombardia nelle PMI cresce progressivamente la consapevolezza e la disponibilità ad investire in istruzione e formazione, allo scopo di costruire un capitale umano lavorativo sia a livello di management che di forza lavoro. Sotto questo aspetto le aziende italiane continuano a esprimersi ben al di sotto della media europea. L'attuazione di varie riforme ${ }^{2}$ nel corso del tempo, ha contribuito in modo significativo ad un progresso nell'attenzione degli operatori verso la crescita del capitale umano in azienda, attraverso la costituzione di Fondi interprofessionali (ad esempio il Fondo Dirigenti PMI per manager e il Fondo Formazione PMI per la formazione PMI), di programmi di formazione aziendali e individuali, e in parte anche attraverso la messa a disposizione di vaucher destinati a corsi di specializzazione. In ogni caso, sono necessari ulteriori e significativi sforzi per assistere le PMI, specialmente quelle di dimensioni più piccole, nell'accesso e nell'utilizzo di tali strumenti e opportunità e favorire in questo modo la crescita dei livelli di competitività e capacità innovativa in una stagione di intensa competizione a livello mondiale.

\section{Imprenditorialità di soggetti immigrati}

La Lombardia ha attirato circa un quarto di tutti gli immigrati registrati in Italia. Deve essere in particolare sottolineato che gli immigrati costituiscono il $14 \%$ della popolazione nella fascia di età compresa tra i 18 e i 25 anni e il dato significativo è che si prevede che questi raggiungeranno quasi il $25 \%$ entro il 2030. I riscontri sul piano internazionale sottolineano il dinamismo imprenditoriale di questa particolare componente della popolazione. La regione potrebbe utilizzare in modo più efficace questo fattore dinamico. Infatti per propria natura e forma mentale, una parte dei migranti, essendo relativamente giovani tendono ad avere una spiccata propensione ad assumersi i rischi fisiologicamente connessi all'attività d'impresa. Per la regione la sfida, e nel contempo l'opportunità, sono rappresentate dalla possibilità di sviluppare meccanismi tali da fornire a tale gruppo sociale le condizioni abilitanti in termini di istruzione, formazione, occupazionale e imprenditorialità.

\footnotetext{
1 Il progetto Global Entrepreneurship Monitor (GEM) è un programma di ricerca internazionale condotto da un consorzio di università. Il suo obiettivo è di analizzare il livello di imprenditorialità in più di cinquanta paesi, i cosiddetti "paesi GEM".

2 Legge 388/2000, Legge 236/93 e Legge 53/2000.
} 


\section{Punti di debolezza}

Frammentazione degli interventi di

sostegno alle PMI

Vi sono molte agenzie e associazioni costituite in rappresentanza dei differenti interessi regionali. La genesi di tale vasto numero di organismi va ricondotta alla storia e all'evoluzione del sistema economico regionale e alle sue già richiamate specificità, differenziazioni e tradizioni. Se da un lato gli elementi di tradizione rappresentano punti di forza e di condivisione di interessi, si ravvisa al tempo stesso l'esigenza di promuovere una piattaforma programmatica per lo sviluppo economico regionale più integrata e coordinata. Ciò potrebbe contribuire in modo efficace a produrre un cambiamento culturale e a sviluppare reti trasversali tra i vari settori, che oggigiorno risultano limitate.

Assenza di obiettivi prioritari nelle

politiche PMI

Le organizzazioni e le istituzioni del settore pubblico hanno promosso vaste misure al fine di sostenere la competitività regionale e per le quali vengono stanziate cifre significative. Tuttavia il quadro delle politiche in favore delle PMI a livello regionale ravvisa una scarsa attenzione nella definizione e nella formulazione di dettaglio degli obiettivi prioritari. Esistono, di conseguenza, margini significativi per sviluppare forme più diversificate e sofisticate di assistenza, in grado di strutturare e articolare interventi e obiettivi specifici in grado di corrispondere alla varietà dei settori e dei comparti chiave come quello delle aziende ad alta crescita.

Formazione per la popolazione adulta

Occorre una maggiore dinamicità nello sviluppo di capacità professionali aggiornate $\mathrm{e}$ in grado di affrontare le nuove sfide rappresentate dalla concorrenza internazionale. Lo sviluppo professionale continuo, il potenziamento delle capacità di leadership e di management, così come i percorsi di aggiornamento e ri-orientamento professionale richiedono tutti che in seno al sistema regionale delle PMI venga data preminenza al miglioramento delle condizioni di competitività $e$ in generale alle precondizioni di base necessarie per la crescita dello spirito imprenditoriale e delle aziende.

Limitato scambio d'idee tra istruzione,

formazione e industria

In una regione caratterizzata da tali e tanti rimarchevoli punti di forza ci si aspetterebbe una maggiore integrazione, più solide interconnessioni tra i diversi soggetti per la creazione di future opportunità di benessere e una maggiore presenza nei mercati internazionali. Se da un lato le singole istituzioni (come l'Università Milano Bicocca e le singole associazioni e camere di commercio) dimostrano un buon livello di interconnessione, peraltro tali legami sono complessivamente meno robusti e numerosi rispetto ad altre regioni di rilevanza mondiale e non sono sempre sviluppati a sufficienza e in misura tale da determinare lo sviluppo di un effettivo sistema d'innovazione locale e da ottenere un effettiva moltiplicazione dei vantaggi derivanti dalla messa il rete delle conoscenze.

Livelli modesti di collaborazione e casi

di successo 
I dati statistici sul numero di brevetti depositati, sulle collaborazioni internazionali in essere e sul coinvolgimento delle PMI nei progetti di maggiore importanza sono piuttosto limitati e modesti per una regione con forti connotazioni dinamiche. Si registra inoltre la mancanza di azioni orientate alla promozione di casi di studio che consentano di condividere le conoscenze acquisite e di dar vita a nuove reti e a innovazioni.

\section{Mancanza di una valutazione \\ sistematica dei programmi di sostegno \\ allo sviluppo delle imprese}

Si registra la mancanza di una valutazione sistematica dei programmi di sostegno allo sviluppo delle imprese. Ad esempio, il programma dedicato alle start-up vale 30 milioni di Euro e rappresenta la continuazione di un programma analogo, della durata complessiva di 11 anni. Nonostante un tale sforzo protratto nel tempo e simili antecedenti, vi sono scarsi riscontri di analisi dettagliate e indipendenti condotte prima di formulare il programma in questione. Di conseguenza, si potrebbero sollevare fondati dubbi sul nuovo programma e sul suo probabile impatto, laddove questo non fosse stato effettivamente costituito sulla base di una precisa comprensione di ciò che ha funzionato o meno per la regione. La valutazione (e il connesso monitoraggio) dovrebbe essere parte integrante di tutti i programmi finanziati da risorse pubbliche, specialmente con riferimento a iniziative incentrate sullo sviluppo del settore privato. La raccolta di dati e informazioni fattuali attraverso azioni strutturate e continue di monitoraggio e valutazione della realtà imprenditoriale è indispensabile per fornire una base di conoscenza reale in grado di informare le scelte di politica regionale.

Si tratta infatti di uno strumento essenziale, atto a fornire indicazioni precise ed affidabili sugli effetti delle innovazioni introdotte a livello di politiche, che rende possibile quindi intervenire con riforme selettive e puntualmente orientate, in grado di sviluppare reti di relazioni, rafforzando la competitività delle imprese sui mercati e stimolando la crescita di sistemi sostenibili e capaci di adattarsi ai mutamenti del contesto di riferimento.

Livello insufficiente di capitalizzazione

In caso di imprese di piccole e piccolissime dimensioni, il livello insufficiente di capitalizzazione costituisce un grave ostacolo per gli investimenti e la crescita e rende le aziende interessate fortemente vulnerabili difronte alle crisi dei mercati del credito. La dimensione limitata e il basso sviluppo dei mercati azionari costituiscono un elemento frenante per lo sviluppo in particolare dell'imprenditorialità più innovativa e per le aziende più dinamiche.

\section{Cultura del credito}

La struttura tradizionale delle PMI si riflette anche nelle modalità prevalente di finanziamento delle imprese locali. La dipendenza sostanziale dal credito bancario e l'affidamento a finanziamenti particolarmente di breve termine comporta una significativa vulnerabilità durante $\mathrm{i}$ cicli di crisi e $\mathrm{i}$ periodi di contrazione del credito.

Sottosviluppo e frammentazione del

mercato dei capitali di rischio

In regione Lombardia il mercato dei capitali di rischio, che dovrebbe sostenere le nuove imprese e la crescita delle PMI, è significativamente meno maturo e poco segmentato rispetto ai mercati del credito. Le problematiche relative alla debole capitalizzazione, unite alla dimensione limitata e alla 
scarsa sofisticatezza dell'offerta di venture capital impedisce la crescita dell'imprenditorialità più innovativa e delle aziende più dinamiche.

Assenza di programmi di preparazione

all'investimento

In regione non sono attualmente disponibili programmi di preparazione all'investimento indirizzati alle PMI. Tali programmi sono orientati ad accrescere la richiesta di finanziamenti partecipativi da parte delle PMI, stimolando per un verso il superamento della avversione e della resistenza di queste verso il venture capital, curando contestualmente l'attrazione di questa forma di investimenti e curando gli aspetti di presentazione delle imprese agli investitori.

\section{Pericoli}

Competizione globale

Altri paesi e regioni stanno sviluppando nuove strategie, programmi di stimolo e incentivo per realizzare condizioni favorevoli alla crescita della piccola impresa e per competere sotto questo aspetto con le regioni tradizionalmente forti. La concorrenza esercitata da queste realtà può assumere varie forme ed essere basata su vari fattori determinanti che vanno dai costi contenuti all'elevato livello tecnologico, in misura tale da cambiare i termini del vantaggio competitivo consolidato nella competizione tra sistemi di imprese. La lungimiranza e la continua ricerca, unitamente alla condivisione dei saperi, sono fondamentali per mantenere un presidio attivo ed un'azione orientata a fronteggiare tali pericoli. Inoltre, nel momento in cui si incominceranno a percepire segnali di inversione di tendenza e di recupero rispetto all'attuale crisi economica, potrebbe emergere un'attitudine orientata ad adagiarsi sui fattori tradizionali di competitività e questo atteggiamento venga a configurarsi come un ripiegamento piuttosto che puntare ad un persistente impegno ad eccellere.

Strutture e capacità imprenditoriali

inattuali nelle PMI

Il ritmo con cui si susseguono i cambiamenti è sempre più rapido e con l'apertura dei mercati in regime di economia globale, la regione deve assicurarsi che le strutture dell'industria, il livello occupazionale e le capacità professionali siano adeguate e competitive per i nuovi mercati.

\footnotetext{
Mancanza di programmazione nella

gestione del passaggio generazionale, di formazione professionale e di piani di formazione continua nelle PMI
}

La conduzione familiare delle aziende rappresenta una caratteristica tradizionale dell'economia regionale; molte PMI sono caratterizzate dalla presenza di un singolo imprenditore "titolare" invece che da un gruppo responsabile della gestione dell'impresa e da una linea di successione individuata con chiarezza. Quando i parenti e i discendenti dei titolari di tali aziende scelgono di non partecipare all'attività di famiglia, numerose imprese, di fronte al problema dell'avvicendamento generazionale nella conduzione dell'azienda, vanno in liquidazione. Di fatto in tutti i settori le PMI della Lombardia si trovano ad affrontare il problema rappresentato dalla successione sul lungo periodo. Tale difficoltà e minaccia risulta essere enfatizzata dall'incapacità e impossibilità, diffusa nei settori tradizionali, di impiegare una forza lavoro più preparata sul piano tecnologico e di dimostrare una effettiva capacità di 
crescere e di espandersi in nuovi mercati. La capacità di dimostrare vitalità e capacità di assorbimento di nuove idee e di adattamento rispetto alle sfide della tecnologia potrebbe costituire un fattore di attrattività per nuovi investitori e imprenditori in settori dell'economia regionale tradizionalmente di grande qualità ma che attualmente versano in condizioni di stagnazione. In conclusione la sfida rappresentata dalla ricerca di nuovi percorsi per il rafforzamento e la professionalizzazione del capitale umano delle PMI e per l'accrescimento della vitalità e della produttività nei settori tradizionali, basati su unità di produzione di piccola dimensione, è strettamente connessa al problema della successione d'impresa (OCSE, 2011).

Difficoltà di accesso a finanziamento e investimento

Gli imprenditori e le PMI si confrontano con molte difficoltà e problemi per riuscire ad accedere a finanziamenti, specialmente durante l'attuale crisi economica e bancaria. Tali finanziamenti sono viceversa essenziali per la sopravvivenza e la crescita delle imprese che operano in ambito regionale.

Cultura e perdita di talenti

L'economia globale è un dato di fatto acquisito che induce la mobilità di imprese e di persone particolarmente qualificate grazie alla facilità di accesso a conoscenze e opportunità, alle comunicazioni e alle interconnessioni in rete. L'Italia è rinomata per la sua cultura, va però tenuto presente che le industrie innovative specializzate in tale settore si raccolgono in regioni in cui la combinazione dei fattori ambientali previsti è più attraente. La qualità delle conoscenze e la condivisione dell'innovazione rappresenta rispetto a ciò un fattore attrattivo importante e in tale situazione la debolezza del sistema Lombardia potrebbe portare ad una fuga di saperi, di capacità e di proprietà intellettuali e di risorse umane, come pure ad una ridotta capacità di attirare nuovi talenti nella regione.

Difficile equilibrio tra l'efficienza degli

istituti finanziari e la loro contiguità

territoriale

I costi di gestione dei consorzi di garanzia fidi risultano accresciuti a causa dell'introduzione di criteri più severi nella vigilanza esercitata sugli operatori finanziari. Costi operativi più elevati rendono il perseguimento di una maggiore efficienza anche più importante, allo scopo di evitare o limitare che tali maggiori costi si trasferiscano sui prezzi dei servizi offerti.

L'evoluzione nella dimensione e nella portata degli schemi di mutua garanzia degli affidamenti in questione richiama un'ulteriore necessità di aggiornamento per le competenze tecniche e organizzative e di sviluppo di nuove capacità e strategie professionali. Va rimarcato il rischio che si possa determinare un allontanamento e allentamento del rapporto tra gli operatori dei consorzi di garanzia da un lato e le PMI e i relativi sistemi locali dall'altro, nel momento in cui per i primi si renda necessario un innalzamento nella scala territoriale e un cambiamento nelle procedure al fine adeguarsi a nuovi regolamenti e competere in un mercato in evoluzione.

\section{Raccomandazioni di natura politica}

Al fine di proporre elementi in risposta alle sfide qui sopra rappresentate si indicano le seguenti principali raccomandazioni di orientamento politico. Queste raccomandazioni vengono sviluppate e discusse con maggiore articolazione e dettaglio nei capitoli del rapporto. 


\section{Scheda 1. Principali raccomandazioni di natura politica}

Ambiente delle imprese e rete di PMI

- Sviluppo delle potenzialità economiche della Lombardia basate sulla sua reputazione imprenditoriale e su reti di piccole imprese dinamiche nel settore manifatturiero e dei servizi considerando dati fattuali aggiornati e utilizzando i principi dello SBA al fine di stimolare ulteriori cambiamenti e miglioramenti.

- Utilizzo delle reti per la costruzione di prospettive di sviluppo su scala globale.

- Adozione di interventi pratici con il coinvolgimento delle PMI per favorire lo sviluppo di imprese e sistemi locali in grado di migliorare le loro prestazioni come pure per promuovere lo sviluppo più robusto della cultura imprenditoriale, dei rapporti tra aziende e dell'efficienza dei loro legami di rete. Tutti questi fattori devono essere considerati in forma coordinata al fine di migliorare la competitività del sistema lombardo in una prospettiva globale che conferisca rinnovata enfasi e valore all'innovazione, all'internazionalizzazione e alla costruzione di reti.

- Raccolta sistematica di dati fattuali ed elementi di evidenza empirica sulle trasformazioni in atto e sulle conseguenze di tali cambiamenti per le PMI. Messa a punto di un sistema di monitoraggio e valutazione che operi su base regolare e permetta l'analisi del contributo dato alla crescita dell'economia regionale dall'ambiente imprenditoriale, dalle PMI e dalle loro reti.

- Creazione di reti per la promozione di opportunità di sviluppo sostenibile nei comparti produttivi della regione.

Imprenditorialità e capacità professionale della forza lavoro

- Rinnovata enfasi alla cultura imprenditoriale.

- Rafforzamento delle iniziative di istruzione e formazione professionale (Vocational Education and Training - VET) esistenti.

- Ottimizzazione dell'accesso delle PMI alle opportunità di formazione e alle iniziative di formazione professionale.

- Rafforzamento dell'accesso all'istruzione e alla formazione professionale per specifici gruppi di interesse (giovani, donne e migranti). È fondamentale per la regione sviluppare ulteriori percorsi, opportunità e programmi per tutti e tre i gruppi individuati, specialmente in relazione allo sviluppo delle competenze e capacità professionali.

Creazione di nuove imprese

- Attenzione prioritaria alla competitività e alle strategie per l'innovazione, comprendendo strumenti per il loro monitoraggio e valutazione (Monitoring and evaluation, M\&E).

- Revisione e miglioramento di programmi e infrastrutture dedicati.

- Revisione e, se necessario, miglioramento degli strumenti fondamentali per il sostegno delle nuove imprese (e di quelle già esistenti). La regione ha necessità di migliorare la sua capacità di comprensione dell'efficacia dei programmi di sostegno e delle modalità di migliorarne l'impatto. Nuovamente il sistema M\&E gioca un ruolo importante a tale fine.

- Miglioramento del sistema di sostegno per imprenditori potenziali/esistenti con informazioni e servizi integrati. Inoltre e più specificamente, garantire che il sito web della Lombardia sia disponibile in inglese $e$ in altre lingue importanti per sostenere una reale internazionalizzazione della regione (non soltanto per la semplice promozione delle esportazioni) e creazione di un singolo sportello informativo 
per le imprese. Tale sportello può essere suddiviso in flussi separati di informazione, sostegno, ecc., specializzati e indirizzati a i) imprenditori potenziali; ii) imprese in fase di "start-up"; iii) accesso a finanziamenti e altri servizi fondamentali, così facilitando l'incrocio e l'interazione tra gli imprenditori e le imprese potenziali e già esistenti con le principali fonti di informazione/sostegno da questi richieste.

- Massimizzare la generazione e raccolta di capacità imprenditoriali.

- Rafforzamento di meccanismi virtuosi di passaggio generazionale perseguendo obiettivi di sostenibilità e redditività di lungo termine, mediante programmi efficaci e adeguatamente finanziati con obiettivi determinati ed effettivi di sensibilizzazione, formazione, e supporto tecnico, legale e finanziario personalizzati.

\section{Reti di conoscenza e innovazione}

- Coordinamento sul piano organizzativo per ottenere la semplificazione degli strumenti e dei pacchetti assistenziali. Sarebbe possibile agire in modo molto più efficiente rendendo più trasparente le possibilità e modalità di intervento a favore delle PMI e la loro azione finalizzata a indurre una domanda più sofisticata da parte delle PMl e stimolare nel contempo un coinvolgimento più sostanziale e orientato al mercato da parte degli istituti di ricerca e degli enti di istruzione superiore.

- Miglioramento del sistema di innovazione e delle attitudini collaborative. È necessario incoraggiare il dialogo con partner, clienti e concorrenti poiché tutti appartengono e contribuiscono allo stesso crogiuolo di saperi in grado di ispirare innovazioni fondamentali per la crescita delle aziende e dell'economia. Le PMI, tutte le imprese, le università e gli istituti di ricerca possono trarre beneficio dalla condivisione di conoscenze e di altre risorse al fine di esplorare e sfruttare nuove opportunità, come pure condividere altri vantaggi che comprendono il contenimento dei costi e la messa in comune di esperienze al fine di evitare il ripetersi di errori costosi.

- Individuazione delle imprese a crescita elevata quali casi esemplari e catalizzatori di dinamiche di sviluppo. Le economie dominate dalla presenza di PMl traggono vantaggio da approcci "open innovation" in cui l'accento venga posto su concrete opportunità di mercato e chiari indirizzi e percorsi di commercializzazione. Tali prospettive e approcci sono divenuti decisivi con l'irrompere della crisi economica e nella fase di ripresa successiva risulteranno essenziali nello sviluppo di value proposition altamente concorrenziali.

- Incoraggiamento di iniziative di servizi orientati all'innovazione.

\section{Accesso alla finanza}

- Ampliamento della gamma degli strumenti finanziari disponibili per le PMI.

- Incoraggiamento di una maggiore partecipazione del settore privato nel finanziamento di imprese innovative.

- Miglioramento della cultura finanziaria e della preparazione agli investimenti. Sostegno agli strumenti di garanzia collettiva al credito e ai consorzi fidi nel perseguimento di una maggiore efficienza preservando nel contempo la loro prossimità territoriale alle imprese.

- Agevolazione di un ruolo più attivo da parte di Confidi nello sviluppo della nuova imprenditorialità e nel sostegno all'innovazione e all'internazionalizzazione delle PMI. 


\section{Scheda 2. Principali aspetti della legge SBA}

\section{P.1. Creare un ambiente in cui gli imprenditori possano prosperare e siano gratificati}

- La regione Lombardia è caratterizzata da elevati livelli di concentrazione di aziende sul territorio, tale rapporto manifesta però un andamento tendenziale negativo e negli ultimi anni il ritmo delle aziende cessanti ha superato quello delle nuove imprese. La problematica relativa alle imprese familiari e al loro avvicendamento generazionale rappresenta un grave e crescente problema che richiede di essere gestito in modo adeguato.

- La regione è generalmente ad elevata vocazione imprenditoriale, sebbene si potrebbe intervenire maggiormente nell'area della cultura imprenditoriale e nella preparazione di competenze d'impresa ai diversi livelli del sistema regionale dell'istruzione e dello sviluppo delle competenze.

- In regione la struttura imprenditoriale e la matrice culturale basata su micro imprese e su aziende a conduzione familiare pone problematiche e sfide che trovano radici profonde in tale struttura e cultura. Se opportunamente condotto, il cambiamento nella cultura e nella struttura delle aziende richiede tempo ed è importante introdurre nuove idee per stimolare imprenditori e aziende a conduzione familiare ad adottare una visione più strategica nel lungo periodo.

- La Lombardia ha costruito un contesto economico forte grazie ad una forte tradizione di imprenditorialità creativa, tuttavia il ritmo a cui procedono i cambiamenti globali richiede maggiore attenzione, data la struttura dell'economia regionale basata sulle PMI e dati i rischi connessi con la mancanza di programmi chiari per le ipotesi di successione alle future generazioni o di cessazione delle attività.

\section{P.3. Formulare regole secondo il principio _"Pensare anzitutto in piccolo"}

- A causa della predominanza delle aziende di piccole e piccolissime dimensioni presenti nella regione, quello in questione rappresenta un principio fondamentale per la Lombardia. Le istituzioni della Regione Lombardia per gli appalti e per la concessione di licenze, comprese le istituzioni locali, riconoscono l'importanza di tale principio ed esistono specifiche iniziative, comprese le pubbliche relazioni e lo sviluppo di strumenti finalizzati ad incoraggiare le PMI a lavorare congiuntamente e in maniera associata, per avere maggiori opportunità di vincere gare e appalti. In ogni caso la capacità dei partenariati e delle collaborazioni di perdurare e mantenersi anche oltre il periodo di sostegno garantito da detti strumenti o a prescindere dall'opportunità immediata data da un singolo contratto rimane una sfida che richiede un costante incoraggiamento, tale da consentire alle piccole imprese di ottenere pieno accesso a tutte le opportunità disponibili.

\section{P.4. Sensibilizzare le amministrazioni pubbliche alle esigenze delle PMI}

- È stato definito il ruolo di "Mr. PMI", quale iniziativa di SBALombardiaLab. Tuttavia, sarebbe possibile un maggiore sforzo e impegno per dare impulso alla politica regionale per le PMI, ad esempio attraverso la elaborazione di una specifica strategia di competitività e innovazione.

- In Lombardia si assiste ad un progresso grazie ad un certo numero di misure pro-attive orientate a migliorare l'attenzione e la risposta alle esigenze e alle problematiche delle PMI da parte della pubblica amministrazione. Questa deve incoraggiare le PMI a divenire clienti più esigenti e a cercare servizi di sostegno più sofisticati per la propria crescita e per la prosperità della regione.

\section{P.5. Adeguare l'intervento politico pubblico alle esigenze delle PMI}

- Diversi strumenti di politica economica sono rivolti al settore delle PMI. Tuttavia, il punto di debolezza fondamentale è costituito dalla mancanza di monitoraggio efficace (in qualche misura) e conseguente limitata capacità valutativa (in grande misura). Senza un'efficace attività di monitoraggio e valutazione non è possibile adattare nel modo più efficace gli strumenti della politica rispetto alle esigenze in evoluzione delle PMI. 
- In Lombardia agenzie e realtà specifiche sono attive in questa direzione e l'iniziativa SBALombardiaLAB è volta a coinvolgere le PMI per sensibilizzarle sugli sforzi compiuti per adattare gli strumenti del settore pubblico alle loro esigenze. Ciò può conferire slancio e indurre nuovi cambiamenti a sostegno delle PMI e nell'efficacia degli strumenti del settore pubblico. adeguato

P.6. Agevolare l'accesso delle PMI al credito e sviluppo di un contesto economico e giuridico

- Per facilitare l'accesso alla finanza da parte delle PMI e in particolare per sostenerle nelle diverse fasi della loro vita, vi è la necessità di ampliare e diversificare la gamma dei servizi finanziari (comprendendo capitale di rischio, business angel, crediti partecipativi, ecc.).

- Gli strumenti regionali di garanzia mutua (Confidi) devono migliorare le proprie prestazioni e la propria organizzazione perseguendo obiettivi di maggiore efficienza; ciò sta avvenendo ma è altresì importante garantire prossimità territoriale e vicinanza alle aziende di tali strumenti in modo da agevolare l'accessibilità a tali servizi anche da parte di quelle di piccole dimensioni.

- II coinvolgimento del settore privato nel finanziamento alle imprese innovative rappresenta un'importante opportunità da perseguire in modo tale da sviluppare forme complementari e integrative rispetto alla copertura offerta dal finanziamento pubblico. Esistono spazi significativi per la sperimentazione di nuove forme di collaborazione tra investitori del settore pubblico e quelli del settore privato.

P.7. Aiutare le PMI a beneficiare maggiormente delle opportunità offerte dal mercato unico e dai mercati dei paesi terzi

- Viene posto un deciso accento sull'“internazionalizzazione": non sembra però esservi una corrispondente comprensione, da parte sia dei politici che degli imprenditori, di ciò che significhi tale prospettiva nella sostanza o di ciò che essa comporti, al di là degli aspetti relativi alla mera "esportazione".

- Molte PMI non sono nella condizione di cogliere le opportunità rappresentate dal mercato unico. Sono stati creati strumenti specifici, compreso il progetto ERGON, per incoraggiare le PMI a considerare le nuove opportunità esistenti; ma si tratta a tutt'oggi di casi limitati. Una maggiore capacità di definire le priorità strategiche nei settori chiave, valorizzando i punti di forza del sistema e il potenziale di maggior crescita, potrebbe consentire alle PMI di accedere a più opportunità offerte dal mercato unico.

P8. Promuovere l'aggiornamento delle competenze nelle PMI e ogni forma di innovazione.

- II panorama della formazione professionale in genere, compresa quella specialistica, è in fase di riforma. È necessario compiere ancora molti progressi per la valutazione dell'offerta formativa e il suo successivo sviluppo, ad esempio attraverso i programmi Poli Formativi e Dote Formazione. È necessario incoraggiare le PMI affinché facciano pieno uso di tutte le opportunità disponibili per accrescere e potenziare il proprio capitale umano, in modo da migliorare il proprio livello di management, di competitività e di innovazione.

P9. Permettere alle PMI di trasformare le sfide ambientali in opportunità.

- Iniziative come SBALombardiaLAB sono impegnate nell'opera di sensibilizzazione e nella predisposizione di canali di accesso alle informazioni e alle misure di sostegno. Altre istituzioni regionali devono continuare a sviluppare un approccio volto a motivare e impegnare le PMI in settori specifici quali quello dell'energia, dello smaltimento dei rifiuti e dei servizi ambientali, che rappresentano le maggiori opportunità di appalto per le PMI.

- L'esigenza di raggiungere gli standard richiesti e accedere quindi a nuove opportunità di affari non viene adeguatamente considerata a causa della prevalente visione prospettica limitata al breve periodo, in base alla quale il soddisfacimento di tali requisiti rappresenterebbe soltanto un costo aggiuntivo invece che la base per lo sviluppo di nuove attività. È necessario stimolare il cambio di tale percezione agevolando il coinvolgimento delle PMI e consentendo di andare oltre la mera messa a 
disposizione di informazioni e facilitare quindi l'accesso, attraverso un'azione di intermediazione, a progetti concreti che possono risultare significativi per le stesse PMI. In tale modo gli interventi possono risultare più efficaci e indurre un cambiamento sul lungo periodo nelle PMI regionali.

P10. Incoraggiamento e sostegno alle PMI per avvantaggiarsi dei mercati emergenti

- La competitività rientra in un disegno globale per la creazione di opportunità nei nuovi mercati emergenti e molte PMI locali potrebbero accedere a nuove fonti di reddito se fosse mantenuto il giusto livello di incoraggiamento. Numerose iniziative hanno portato delegazioni di PMI a visitare potenziali acquirenti in altri paesi, comprese missioni in Russia e Cina; tale approccio per promuovere l'internazionalizzazione potrebbe essere ulteriormente ampliato.

- Sono in programma iniziative politiche volte a sostenere settori strategici come quello aerospaziale, delle tecnologie dell'informazione e delle comunicazioni, delle biotecnologie, della progettazione, delle energie rinnovabili, dei nuovi materiali, della bioedilizia, ecc.

- I paesi BRIC costituiscono la prospettiva sostanziale per crescita futura del PIL e dei mercati dell'esportazione, eppure poche sono le PMI che prendono in considerazione tali paesi o esportano verso essi. La dipendenza dai tradizionali mercati a crescita lenta tende ad essere un fattore di limitazione per lo sviluppo ed è quindi fondamentale che le iniziative per la creazione di reti di relazione promuovano una maggiore internazionalizzazione, quale parte di strategie politiche olistiche orientate a competitività, innovazione e crescita. La Lombardia presenta un certo numero di punti di forza essenziali e una gamma di iniziative in corso che coinvolgono altri partner e SBALombardiaLAB in particolare. Tali iniziative riconoscono che la globalizzazione e l'accresciuta pressione esercitata dalla nuova natura della concorrenza hanno reso fondamentali aspetti come l'innovazione e un livello più dinamico di collaborazione tra imprese. Inoltre molto potrebbe essere fatto per lo sviluppo di reti di conoscenza e per incoraggiare maggiore capacità di innovazione da parte di PMI e relativi partner. 


\section{EXECUTIVE SUMMARY - EN}

Lombardy is one of the leading regions in Europe, and is the Italian region with the highest concentration of people, business and wealth. With 9.8 million inhabitants, this represents $15.9 \%$ of the overall national population and approximately $20.6 \%$ of national GDP is produced by the region.

Figure 2. Regional contribution (\%) to national GDP growth (1995-2007)

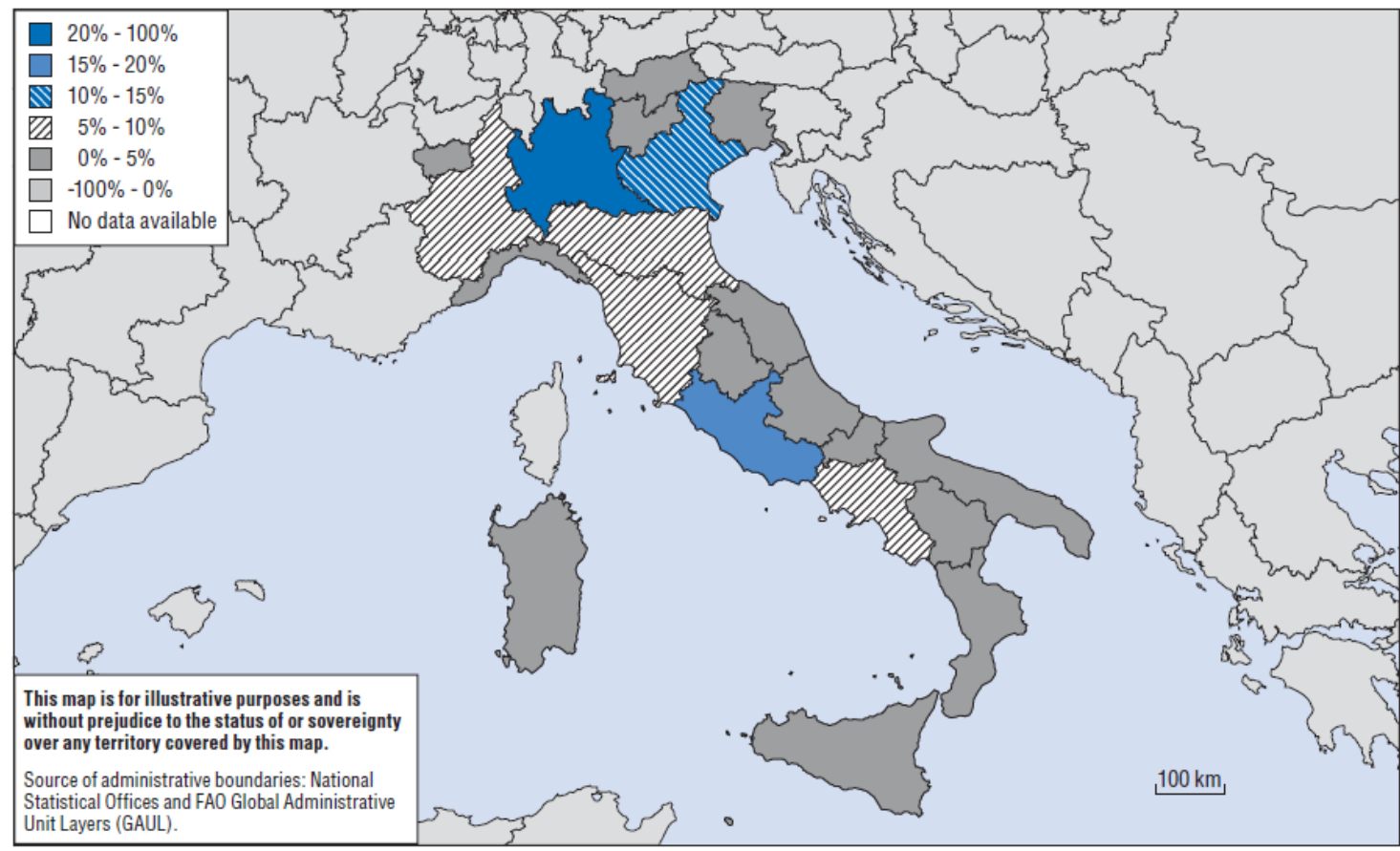

Source: OECD Regional Outlook 2011: Building Resilient Regions For Stronger Economies, Calculations based on Cambridge Econometrics and OECD Regional Database (2009).

One of the main characteristics of the Lombardy economy is the small scale of firms. In 2009 there were 823268 companies employing more than 4.3 million people. SMEs are the real backbone of the Lombardy economy.

The past resilience of the small business activity has been based on continuous product improvements. With the openness of markets and truly global competition, there is an increasing requirement to compete at the higher value market segments and demonstrate an ability to innovate and internationalise. Moreover, as highlighted in a recent OECD report on higher education in the Lombardy region (OECD, 2011), the region is undergoing a profound industrial shift towards services and knowledge-intensive activities, but retains a significant manufacturing sector, which is under pressure from global competition.

In 2010, the Lombardy workforce was predominantly employed in the service sector (64\%). The manufacturing sector continues to employ a higher proportion of the regional workforce than Italy as a whole (33.5\% vs. $27 \%)$. At the same time, however, the employment rate in high and medium tech manufacturing remains low at $10.9 \%$ (vs. for example Stuttgart (21.2\%) and Piedmont (12\%)). 
In this very challenging period, characterised by a global economic downturn and a rising unemployment in most OECD countries, the Region Lombardy has decided to undertake a wide exercise of review and assessment of its capacity to support new enterprise creation and the development of small and medium enterprises (SMEs). This will also examine how it can be enhanced through the implementation of the EU Small Business Act (SBA) and local economic and employment development policy interventions. The aim is to contribute to the creation of a more entrepreneurial economy that offers improved job creation and employment opportunities, increased economic growth and adaptability to shocks, and innovation in meeting social needs.

The key objectives of the project, jointly implemented by the OECD LEED Programme and Unioncamere Lombardia, are to:

- analyse local framework conditions for new enterprise creation and SME development in Lombardy region;

- assess policies undertaken in the region to develop entrepreneurial people, new enterprise creation and healthy SME development; and

- contribute to policy development in the region by proposing policy options to overcome barriers and realise further potential.

This review report aims to provide, from an international perspective, advice on policies to strengthen and restructure the business environment for SMEs in the Lombardy region following the EU framework of the Small Business Act.

There is an important focus on achieving a coherent policy framework through the development of an effective SME and entrepreneurship strategy and an effective policy delivery which brings together all the key stakeholders. The recommendations made also seek to address the need to enhance the links between policy makers, the business community, the universities, researchers and practitioners for policy learning and development.

The report also describes 'learning model' programmes from other countries with the aim of helping to illustrate how to address the recommendations.

The report is based on observations, discussions and recommendations collected through an OECD peer review process run by a team of OECD economists and international experts and on the results of a survey prepared by the OECD and completed by local policy makers and practitioners. The review report is based on the following nine SBA principles:

- P.1. Create an environment in which entrepreneurs and family businesses can thrive.

- P.3. Design rules according to the "think small first" principle.

- P.4. Make public administration responsive to SMEs.

- P.5. Adapt public policy tools to SME needs.

- P.6. Facilitate SMEs access to finance and develop an appropriate legal and business environment.

- P.7. Help SMEs to benefit more from the opportunities offered by the single market. 
- P8. Promote the upgrading of skills and all forms of innovation.

- P.9. Enable SMEs to turn environmental changes into opportunities.

- P.10. Encourage and support SMEs to benefit from the growth markets.

The analysis has been conducted through the application of an assessment framework that includes specific criteria developed by the OECD LEED for its series of projects on: "Assessment of the local dimension of the Small Business Act (SBA) Principles" and "Boosting Local Entrepreneurship and Enterprise Creation".

The key steps of the methodology are described briefly below:

\section{i. Collection of data and diagnostic.}

A local working group was established by Unioncamere Lombardia, which provided relevant background information and documents in English. This working group also assisted OECD experts in the collection and systematisation of information and data. The OECD has also prepared an assessment grid with a connected questionnaire that has been completed by local policy makers and practitioners to identify local entrepreneurship policy approaches. The assessment grid is based on the SBA and several policy analysis and recommendation documents of the EC and the OECD. It is structured in nine parts, similar to the SBA principles. Each part has a set of indicators. For each indicator five levels have been defined.

With the support of Unioncamere Lombardia, the questionnaire was submitted to 90 selected actors belonging to the following groups of local policy actors:

1. Main regional governmental organisation responsible for policy design and implementation in the focus areas of the project;

2. All regional governmental and non-governmental organisations operating in the territory and whose main task or whose mission is concerned with the promotion of entrepreneurship and SME development and the design and delivery of economic development strategies:

a. regional government departments;

b. development agencies, corporations or area-based partnerships;

c. business support and business representative organisations;

d. education and training providers;

e. formal established networks, such as chambers of commerce, etc.

\section{ii. Review panel visit}

The OECD Secretariat led an international review panel in two peer review visits to the Lombardy region from 11-13 April and from 17-18 of May 2012. During the study visit, the expert team interviewed local and regional policy makers and other relevant actors in the entrepreneurship and SME development system and obtained their views on issues considered relevant by the review panel members and the OECD Secretariat. A wide range of issues were discussed with stakeholders, providing a variety of perspectives on the region and it's SME, entrepreneurship and local development policies. 


\section{iii. Final report}

A final report has been prepared, drawing on the results of the peer review exercise and is organised as follows.

The key areas of policy interest, developed in five thematic chapters are:

- Business Environment and SME Network examines the regional framework conditions and their influence on entrepreneurship and SMEs.

- Entrepreneurship and SME Workforce Skills looks at the way a comprehensive set of skills for enterprise creation can be instilled by appropriate policies in university and vocational education and in continuing professional development.

- New Enterprises Creation focuses on the right mix and combination of factors and conditions which is required in order to ease new business generation and corresponding policy actions.

- Knowledge Networks and Innovation looks at the potential new value that innovation networks can release through their effectiveness in lowering the barriers to collaboration.

- Access to Finance discusses the SME financing gap and the rationale for policies in this area.

The final chapter (chapter 6) provides key overarching conclusions. The Annex I contains a collection of 11 international 'learning model' programmes, which present how other regions have reacted to challenges similar to those faced by the Lombardy region in order to inform the process of developing responses to the policy recommendations.

\section{Challenges and opportunities}

\section{Strengths}

Competitive economic output

One of the strengths of the Region is its economic performance. Lombardy, despite the general economic downturn, remains one of the most competitive regions in Europe according to output figures/regional GDP contribution.

High male employment rate

The level of unemployment is low and the employment rates remain high for males. This stems mainly from the articulated industrial structure and abundance of SMEs with competitive strengths largely organised in defined sector clusters. In addition, the growing strength of Milan has attracted firms and commuter workers from across northern Italy, especially in the service sector. However, despite the high level of employment, the Region has experienced stagnation in labour productivity caused by a range of factors including low levels of educational attainment and the entry of low skilled workers in the labour market. 
Traditional quality and local supply

chains

The Region has developed a strong local supply chain which provides thickness to capture and retain more value in the region. There is a dynamic set of relationships between different players where knowledge and networks are fundamental to wealth creation.

Articulated presence of business

representative and support

organisations

The widespread presence of business associations and organisations, with a complex structure at provincial and regional level, increasingly co-operate and promote a range of initiatives. A notable one is the SBALombardiaLAB, which aims to improve the business environment and animates the current debate on policies to support SMEs development. The agencies support the entrepreneurial system by providing financial aids to improve competitiveness and bring businesses together to form networks and consortia for joint tender bids. This encourages further networking, collaboration, international development and innovation.

High quality of the higher education

and research system

Lombardy hosts some of the top universities in Italy, The 15 universities and around 220000 students are well distributed across the territory and demonstrate impressive performance in attracting many international students, research funding and in producing knowledge and publications. The volume of higher education research is significant and recognised for its quality. The majority of Italian R\&D activity is concentrated in Lombardy, and the share of business R\&D is the highest in Italy after Piedmont. As a result, the Regional Innovation System has been strengthened in the recent years.

Vibrant population with relevant

presence of immigrants

The growing levels of diversity, including the large influx of migrants to the region, are a point of strength for the Region as well as a potential source of entrepreneurship: about $25 \%$ of the country's documented immigrant population is located in the Lombardy region. Some are relatively well-educated; others are not. However, by their very nature, such migrants tend to be relatively young, willing to take risks and naturally entrepreneurial in mind-set. Indeed, discussions with business associations in Lombardy confirm the dynamism of foreign enterprises, even during the recessionary period.

Financial capital of Italy with a high

density of financial intermediaries

The region includes the city of Milan, a recognised financial capital of Europe, which hosts the most important Italian stocks. The regional financial system is characterised by a high density of financial intermediaries, which persists in spite of the important process of consolidation that has been taking place since the 1990s. Indeed, regional banks have been the main players in the most important merger and acquisitions (M\&A) operations in Italy, which led to the creation of sizeable bank groups, Intesa San Paolo and Unicredit. In 2008, 23.5\% of Italian banks had their 
legal seat in Lombardy. Furthermore, the region hosted $79 \%$ of affiliates of foreign banks that are active in Italy (Schena, 2010).

At the same time, the region accounts for a non marginal share (10.8\%) of Italian credit cooperative banks, which grant loans to all economic categories represented among the owners.

Extended network of Mutual Guarantee

Schemes

The extended network of Mutual Guarantee Schemes (Confidi) plays a key role in the system of SME financing in Lombardy. The 2011 survey by Unioncamere Lombardia covering 31 regional Confidi, identified 238000 firms associated to these schemes. Historically, the Confidi system has been highly fragmented, with a large number of small schemes serving specific groups of enterprises and territories. However, over the last five years, the process of consolidation that has characterised the entire financial system has also affected the Confidi structure. At the regional level, a significant process of aggregation has been taking place and medium-size players, which in some cases operate at the national level, have emerged. Nowadays, the main players control about $76 \%$ of the regional market.

Good performance in terms of prompt

payment by public administration

In many territories, private enterprises often experience difficulties in obtaining timely payments when dealing with the public administration: the public administration often performs delayed payments, with possible damages to private companies. The situation in Italy is similar in all the regions with the exception of Lombardy, where the Regional Public Administration has adopted constraining measures to reduce the payment delays to 60 days.

\section{Opportunities}

Existence of well established and

renowned clusters

The region has powerful sectors and high value clusters. These are capable of being developed further with incentives from the business environment and further networking to exchange knowledge, especially at the margins where sector synergies could offer opportunities for SMEs to exploit additional value. Indeed, previous OECD work demonstrates that clusters contribute to the dynamic for enterprise creation, notably by stimulating the creation of spin-outs in core cluster sectors, and also by the creation of economic activity through increased demand for indirect services (i.e. induced activities) (OECD, 2009).

\section{Regional diversity and basis for growth}

Lombardy has a diverse industrial representation across production and services sectors, traditional and modern, which could be developed through networking by SMEs entering more markets where future growth prospects are good. There is strong potential for new growth paths based on what the evolutionary economists call 'related variety'. This means that many skills and innovations are transferable from industry to industry and into new hybrid activities because no activity is far away cognitively, geographically or structurally from existing main industries (Potter, J., A. Proto and M. Marchese, 2010). 
Higher education and research spin-outs

The rich stock of expertise, ideas, knowledge and networks in the higher education sector could be linked more strongly with SME development and promoted with incentivises including tax breaks, vouchers and bespoke shared premises. As already reported in the specific OECD review dedicated to higher education organisations, in the 2000s, efforts have been made to strengthen the links between universities and science parks and to create technology transfer offices. These new infrastructures have delivered positive results: there is an increasing trend in university patenting; the number of spin-offs linked with university research has grown dramatically albeit from very low levels at the beginning of the decade. Apart from the Politecnico di Milano, universities are also less active in providing services to firms. In that context, co-operation between universities is at early stages of development.

Targeted support for "Gazelles"

There are many areas where high growth start-ups and growth SMEs could be targeted for specific in-depth assistance, collaborations and new initiatives to promote faster growth and access to significant resources and networks. Such actions, including filling critical gaps in supply chains, are linked to exploitation of the regional assets, sector and cluster strengths, inward investment and commercialisation from the Higher Education sector.

Untapped potential of female

entrepreneurship

The OECD recognises the value of an increased participation of female entrepreneurs as a source of economic growth and equality. The ratio of female to male entrepreneurs varies across countries but women entrepreneurs are generally outnumbered by men. In innovation-driven countries, men are generally twice as likely to be involved in early-stage entrepreneurial activity as women. In Italy, however, the ratio is equal to 2.3 men for each woman among early-stage entrepreneurs. Furthermore, there are even fewer women among established entrepreneurs: the ratio (2.5 men for each woman) is one of the lowest among $\mathrm{GEM}^{3}$ countries. Lombardy is not an exception and this too, provides significant untapped potential for Italy and Lombardy generally.

Growing awareness in SMEs of the

importance to invest in education and

training

SMEs in Lombardy, despite often being micro, self-employed and family run businesses, are increasingly aware of and willing to invest in education and training in order to build-up the human capital of management and workers. Italian firms continue to perform well below the EU average in this respect. The advent of various reforms ${ }^{4}$ has contributed greatly to the process through the establishment of the Interprofessional Funds (e.g. Fondo Dirigenti PMI for SME managers and Fondo Formazione PMI for SME training), company and individual training plans, partly through vocational training vouchers. However, much more effort needs to be made to

3 The Global Entrepreneurship Monitor (GEM) is a global study conducted by a consortium of universities. Its objective is to analyse the level of entrepreneurship occurring in more than fifty countries, the so called "GEM countries". 
assist SMEs, especially the smaller enterprises, to maximise access and use of these initiatives so as to boost levels of competitiveness and innovation at a time of intense global pressure.

Immigrant entrepreneurship

Lombardy has attracted around $25 \%$ of all registered immigrants in Italy. Furthermore, they constitute $14 \%$ of the 18-25 age group and are projected to increase significantly to almost $25 \%$ by 2030. International evidence stresses the entrepreneurial dynamism of this particular group, which could be more effectively utilised by the region. By their very nature, such migrants tend to be relatively young, willing to take risks and are naturally entrepreneurial in mind-set. The challenge and, at the same time, the opportunity for the region will be to develop mechanisms to provide the necessary education, training, employment and entrepreneurship opportunities for this target group.

\section{Weaknesses}

Fragmented assistance

There are many agencies and associations representing different regional interests. The rationale for this number of organisations is historical and while such tradition has strength and community of interest spirit, there is a need to promote a more unified economic development platform and framework. This could work to effect cultural change and develop cross sector networks which appear limited at present.

Lack of prioritisation on SME policies

Broad competitiveness measures and significant expenditures are allocated by public sector organisations but there is little evidence of sophistication in prioritisation of SME policies. There is scope to develop more nuanced forms of assistance that stratifies interventions and targets specific goals with key groups such as high growth businesses.

Neglected adult education

There is a need for increased dynamism in the development of skills and upgrading to meet the new challenges of global competitiveness. Continuous professional development, leadership and management development as well as re-training all require to be given prominence within the SME community to improve competitiveness conditions and the overall basis for entrepreneurship and business growth.

Limited cross-fertilisation of ideas

between education and industry

In a region with so many basic strengths there would be an expectation of more connections to generate future wealth opportunities and greater international market involvement. While individual institutions (such as Milano Bicocca University and individual chambers and associations) do have many good links these are not as numerous as in other globally significant regions and do not always appear to be maximised to develop the local innovation system and multiply the benefits from knowledge networking. 
Modest levels of collaboration and

success stories

Statistics on the number of patents registered, international collaborations and SME involvement in major projects are modest for such a dynamic region. There is also a lack of promotion of case studies to share learning and spark new networking and innovation.

Lack of systemic evaluation of

programmes to support enterprises'

development

There is a lack of systemic evaluation of programmes to support enterprise development. For example, the Start-up programme is worth Euro 30 million and is the successor to a programme that was implemented for 11 years. However, there is little evidence of a detailed and independent evaluation having been carried out before formulating the Start-up programme. Consequently, legitimate concerns may be raised about the new programme and its likely impact, if it has not sought to build on what has worked or not worked in the region. Evaluation (and monitoring) should be part and parcel of all programmes involving significant public funds, especially in relation to initiatives focusing on private sector development. Evidence gathering through monitoring and evaluation of the business environment has been shown to deliver real learning that can inform regional policy choices. This is vital in drawing lessons from policy innovations, looking for selective and narrowly targeted reforms, and can develop stronger networks, market competitiveness and sustainable, adaptive systems.

Low degree of capitalisation of SMES

In the case of micro and small firms, the low degree of capitalisation represents a serious impediment to investment and growth and makes these firms highly vulnerable to downturns in credit markets. The small scale and limited sophistication of the equity market limits in particular innovative entrepreneurship and highly dynamic firms.

Persistent loan culture

The traditional structure of the majority of SMEs is also reflected in the financing of local companies. The dependence on debt, and the reliance especially on short term funding, results in significant vulnerability at cycle downturns and periods of credit tightening.

Under-developed and fragmented risk capital market

The market for risk capital, which should support new entrepreneurs and SME growth, is significantly less mature and non-segmented compared to the credit market. Capitalisation issues and the small scale and limited sophistication of the equity market inhibit growth of innovative entrepreneurship and highly dynamic firms.

Absence of investment readiness

programmes

Investment readiness programmes, which seek to increase SME demand for equity finance, addressing equity aversion, investment attractiveness and presentational issues, are not available for SMEs in the region. 


\section{Threats}

Global competition

Other countries and regions are developing new strategies and incentives to promote the conditions for SME growth and to challenge traditionally strong regions. Competition from other regions and countries can take various forms, from low cost basis to high knowledge content basis that changes previous competitive advantages. Foresight and continuous research alongside knowledge sharing is essential to maintain vigilance on such threats. Moreover, as the economic crisis abates, an attitude may emerge where settling back into what is traditionally acceptable becomes a fall-back position rather than striving for excellence.

\section{Outdated structures and skills in SMEs}

The pace of change is faster than ever and with the openness of the global economy, the region must ensure that industry structures, employment participation and skills are appropriate and competitive for global markets.

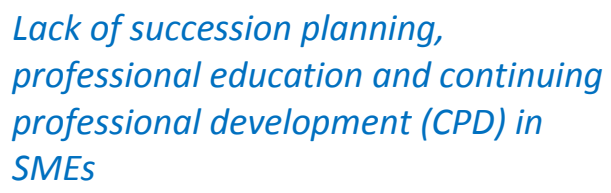

The family business is a traditional structure and many are identified with a single owner rather than a management team and identifiable successors. Many family businesses face problems in reproducing themselves if relatives of business owners choose not to go into the family business. Thus when the owner retires, many businesses cease. Lombardy's SMEs in all sectors are facing this critical long-term issue of succession. Moreover, the general inability of the traditional sectors to incorporate a more technologically skilled workforce and demonstrate the capacity to grow and expand into new markets makes the threat bigger. The demonstration of technological vitality would attract new investors and entrepreneurs to the high quality but currently stagnant sectors of the regional economy. Thus the challenge of finding ways to upgrade human capital skills and increase the vitality and productivity of the traditional sectors, such as those in smallscale manufacturing, is related to the succession issue (OECD, 2011).

\section{Funding and investment}

Entrepreneurs and SMEs face many challenges to access funds especially in the current economic and banking crisis. Such funding is critical for sustaining and growing regionally based businesses.

\section{Culture and loss of talent}

Global economics is a reality and ease of access to knowledge and opportunities, communications and networking can lead to businesses and key people relocating. Italy is renowned for culture however specific innovative industries cluster in regions where the combination of environmental conditions is most attractive. The quality of knowledge sharing and innovation is a factor in this and weaknesses in the Lombardy system could lead to an outflow of knowledge, IP and human resources as well as a reduced ability to attract new talent into the region. 
Difficult balance between efficiency and territorial proximity of financial institutions

Administrative costs have increased as a result of more stringent supervision requirements associated with the introduction of guarantee schemes. This higher cost of operation makes efficiency ever more important, with the aim of limiting the transfer of these higher administrative costs to the prices of the services provided.

However, the change in scale and scope of these schemes also demands an upgrade of technical and organisational competences and the development of new skills and strategies, If a change in scale and procedures is needed, to comply with the new regulation and compete in a changing market, a concern exists that the greater scale may come at the cost of loosening the relationship these schemes have with SMEs and their local systems.

\section{Policy recommendations}

In response to the above mentioned challenges, the following main policy recommendations are offered. They are developed and discussed in more detail in the report.

\section{Box 1. Main policy recommendations}

Business environment and SME networks

- Developing the economic power base of Lombardy and its reputation for entrepreneurship and networks of small dynamic manufacturing and service sector firms with up to date evidence and using the principles of the SBA to inspire further change and improvements.

- Using networks to encourage global perspectives.

- Use practical interventions and engagement with SMEs to foster enterprise and cluster development that can improve performance as well as deeper development of business culture, enterprise linkages and network efficiencies. All this can be brought together to improve competitiveness with a global perspective that places new values on innovation, internationalisation and networking.

- Gathering evidence of transformation and SME change effects. Monitoring and evaluation evidence should be gathered regularly with analysis of the contribution of the business environment and SME networking to economic growth.

- $\quad$ Networking to promote sustainable development opportunities in sectors.

Entrepreneurship and workforce skills

- Renewed emphasis on a culture of entrepreneurship.

- $\quad$ Strengthen existing Vocational Education and Training (VET) initiatives.

- Maximise SMEs' access to training opportunities and capacity building initiatives.

- Strengthen access to education and vocational training to key target groups (youth, women and migrants). It is critical for the region to develop additional pathways, opportunities and programmes for all three target groups, especially in relation to the skills development. 


\section{New enterprise creation}

- Focus on a competitiveness and innovation strategy, including monitoring and evaluation (M\&E).

- Review and improve programmes and infrastructure.

- Review and, if necessary, improve the fundamentals of enterprise support for new (and existing) enterprises. The region needs to address whether the programmes of support are effective and how to enhance their impact. M\&E will be important.

- Improve the system with integrated information and services for potential / actual entrepreneurs. In addition and more specifically, ensure the Lombardy website is available in English and other key languages in order to support real internationalisation of the region (not only simply export promotion) and create a single window of information for enterprises. This window can be divided into separate streams of information, support, etc. for i) potential entrepreneurs; ii) start-ups iii) access to finance and other key categories, thus signposting potential and actual entrepreneurs / enterprises to the main forms of information / support demanded.

- Maximise the pool of entrepreneurial talent.

- Re-invigorate firm transmission mechanisms for long-term sustainability and profitability through effective and well-resourced programmes focusing on awareness raising, customised training and targeted technical, legal support and financial support.

Knowledge networks and innovation

- Organisational alignment to simplify assistance packages. Much more could be done to clarify the interventions and how they perform to stimulate more sophisticated demand from SMEs as well as enticing more meaningful commercially based engagement by and with research and higher education institutes.

- Improving the innovation system and collaboration. Conversations with partners, customers and competitors should be encouraged as they are all part of the knowledge mix that can inspire critical innovations for business and economic growth. SMEs, all companies, universities and research institutes benefit from sharing knowledge and other resources to open new opportunities as well as other benefits including lower costs and shared learning to avoid repeating costly mistakes.

- Targeting high growth enterprises as exemplars and catalysts. Economies dominated by SMEs gain more from an open innovation approach where the emphasis is on practical market opportunities with clear commercialisation routes. This has become more critical with the economic crisis and will be essential in developing high value competitive propositions post crisis.

- Encouraging service innovation initiatives.

Access to finance

- Broaden the range of financing instruments available to SMEs.

- Encourage greater participation by the private sector in the financing of innovative firms.

- Improve financial education and investment readiness. Sustain credit guarantee schemes in achieving greater efficiency while maintaining territorial proximity.

- Favour a more active role by the Mutual Guarantee Schemes' (Confidi) in the development of new entrepreneurship and the support of SMEs' innovation and internationalisation. 


\section{Box. 2. SBA main considerations}

\section{P.1. Create an environment in which entrepreneurs and family businesses can thrive}

- The Lombardy region does well in terms of firm density, though this is declining and the firm death rate has exceeded the birth rate in recent years. The issue of family business and transmission is a serious and growing concern which must be managed effectively.

- The region is generally entrepreneurial, though more could be done in the area of entrepreneurship learning and preparation at all levels of the education and skills development system.

- The structure and cultural emphasis on micro and family businesses in the region means that many challenges are deep rooted in Lombardy. Changing culture and structure takes time if it is to be done properly and it will be important to introduce fresh thinking to stimulate entrepreneurs and family businesses to look more strategically at the long term prospects.

- There is a strong history of creative enterprise that has established a strong economic region but the pace of global change necessitates closer attention given the structure of the regional economy which relies on SMEs and the risks surrounding no clear exit or succession planning for future generations

\section{P.3. Design rules according to the "think small first" principle}

- Given the predominance of micro and small businesses in the region, this is a key consideration for Lombardy. Procurement and licensing institutions in Lombardy region, including the local authorities, do recognise the importance of this and there are active initiatives to promote the principle including Public Relations and instruments that encourage SMEs to work together in accessing more opportunities to win business. However the strength of partnerships to endure beyond the period of the instrument assistance or single contract opportunities remains a challenge that requires consistent encouragement to enable small businesses to gain full access to the opportunities available.

P.4. Make public administration responsive to SMEs

- A "Mr SME" role has been created, as has a SBALombardiaLab initiative. However, more could be done to target SME policy, such as a through a dedicated competitiveness and innovation strategy.

- There is progress with a number of pro-active measures in Lombardy to improve public administration recognition and responsiveness to SMEs. Public administration must encourage SMEs to become more demanding customers and seek more sophisticated support services to assist SME growth and sustained regional prosperity.

P.5. Adapt public policy tools to SME needs

- Various policy tools are targeted at the SME sector. However, a key weakness is the lack of effective monitoring (to some extent) and evaluation (to a large extent). Without effective M\&E it is not possible to adapt policy tools with best effect to meet changing SME needs.

- $\quad$ Specific agencies and initiatives in Lombardy are moving in this direction and the SBALombardiaLAB initiative draws SMEs into the forum to raise awareness of how public policy tools are adapting to meet their needs. This can develop momentum and spark further changes that assist SMEs and the effectiveness of public policy tools.

P.6. Facilitate SMEs' access to finance and develop an appropriate legal and business environment

- In order to facilitate the access to finance for SMEs and in particular to support them in the different stages of their lifecycle there is a need to widen and diversify the range of financial services (including risk capital, business angels, mezzanine finance, etc.).

- Regional mutual guarantee schemes (Confidi) must improve their performances and re-organisation 
aimed at gaining greater efficiency; this is on-going but it is also important to ensure the territorial proximity of these schemes to target firms easing accessibility by smaller businesses.

- The involvement of the private sector in financing innovative businesses is a relevant option to be pursued in order to complement the public funding. There is scope for experimenting with new forms of cooperation between public and private investors.

P.7. Help SMEs to benefit more from the opportunities offered by the single market

- There is a very strong regional focus on "internationalisation". However, there does not seem to be a deep understanding of what this really means or what it entails on the part of both policy makers and entrepreneurs, beyond the issue of "export".

- Many SMEs are not in a position to reach the opportunities of the single market. Specific instruments including ERGON project have worked to encourage SMEs to explore new opportunities but these are small in number at present. Further strategic prioritisation in key sectors of strength and greatest potential growth could enable SMEs to access more opportunities in the single market.

P8. Promote the upgrading of skills and all forms of innovation

- The general skills environment, including vocational educational, is in the process of being reformed. Much needs to be done to evaluate and further develop it, for example the Poli Formativi and the Dote Formazione systems. SMEs must be encouraged to make full use of all the opportunities available to raise their human capital, so as to enhance management, competitiveness and innovation levels.

P9. Enable SMEs to turn environmental changes into opportunities

- Initiatives such as SBALombardiaLAB have been working to raise awareness and provide channels to access information and assistance. Other institutions in the region must continue to develop their approach to engage SMEs in specific sectors such as energy, waste treatment and environmental services where major contracts opportunities exist for SMEs.

- The need for achieving standards and accessing new business opportunities remains underappreciated with a short-term perspective that such requirements represent an additional cost burden rather than a basis for developing new business. There is a need to change this perception by facilitating SME engagement and going beyond the provision of information to broker real projects that can become demonstrators for SMEs. In this way, interventions can be more productive and stimulate long term change from within SMEs.

P10. Encourage and support SMEs to benefit from the growth markets

- Competitiveness is a global concept which is creating opportunities in new emerging markets and many local SMEs could access new sources of revenue if the appropriate encouragement is maintained. Numerous initiatives have taken delegations of SMEs to visit potential buyers in other countries including missions to Russia and China and this should be expanded to promote internationalisation.

- Policy initiatives to support strategic sectors such as aerospace, ICT, biotech, design, renewable energies, new materials, green construction, etc. are planned.

- The BRICs countries are the source of future growth in GDP and export markets yet few SMEs explore or export to these territories. The dependence on low growth traditional markets will limit growth and it is essential that networking initiatives promote more internationalisation as part of holistic policy strategies on competitiveness, innovation and growth. Lombardy has a number of fundamental strengths and a range of initiatives underway through partners and the SBALombardiaLAB in particular. These initiatives recognise that globalisation and the increased intensity of competitive change pressures have made innovation and more dynamic levels of inter-firm co-operation essential. However much more could be done to develop knowledge networks and encourage more innovation by SMEs and partners. 


\section{CHAPTER 1: BUSINESS ENVIRONMENT AND SME NETWORKS}

\section{Introduction}

Healthy economies generate a large and continuous volume of new start businesses and a significant proportion that go on to survive and grow to some size. Achieving this alongside the development of existing businesses is a real challenge even when there is a stock of assets and positive enabling factors in the regional economy. Creating the right business environment and conditions for this to happen is vitally important.

Business networks are conduits for stimulating and supporting SME creation, survival and growth. The combination of a conducive business environment and networks for SMEs to come together provides the basis for developing strength and resilience in the regional and national economy.

A favourable business environment for sustainable growth, including stable and competitive taxes and a culture of enterprise, is fundamental. This foundation is essential for economic growth and development of a dynamically competitive economy where SMEs play a prominent role in generating a range of benefits.

The business base and inter-firm networks have become powerful instruments for building local economic capacity, enabling regions to compete in the global marketplace. The dynamism of SMEs and business networks, including Industry clusters, play a significant role within a successful economy.

\section{Business environment and SME networks: some findings from research literature}

Various studies have identified the importance of the business environment and SME networks to economic success. At a regional level, writers have found at least three areas for attention:

- importance of external economies for localised production systems;

- positive regional cultures and local institutional fabrics - often referred to 'institutional thickness' (Amin and Thrift, 1992; MacLeod, 1997);

- locational proximity which generates trust among business partners.

The concept of institutional thickness puts emphasis on the social and cultural factors underlying the economic success of regions. Factors contributing to institutional thickness are: a strong institutional presence; high levels of interaction; defined structures of domination and/or patterns of coalition; a mutual awareness of being involved in a common (regional) enterprise (Amin and Thrift, 1994). A strong and positive combination of these factors can act to consolidate the local embeddedness of industry, which is closely linked to particular regional cultures. 
Co-operation between organisations within markets has long been identified as a key factor in economic success. Keeble et al (1998) demonstrated that firms in the early stages of development benefit from location within a formal or informal networking environment. There are benefits both in international and local networking activities in research collaboration, labour recruitment, ownership and facilities location. Also, high levels of international networks tend to be correlated with above average levels of local networks.

Supply chain linkages are also vitally important, especially connecting to global supply chains which offer greatest growth prospects as well as protection from downturns. The resilience of global supply chains to crisis shocks has wider positive effects in that those who are connected to them recover better and are more open to self-reinforcing global standards of performance. Integrating SMEs into supply chains to cluster can create regional branding and a critical mass to compete, such as the Made in Italy concept.

The Japanese concept of the "Flying Geese" model has been extended to other Asian economies, including China and India, where local firms national supply chains are extended beyond national borders to connect globally. Networks that connect with multinational companies and foreign direct investors in a region can open doors to international growth as well as knowledge of strategy and business processes to improve productivity and growth of local economic actors. Creating linkages and fostering business relationships with inward investors also strengthens global supply chains.

Developing competitive supply chains involves choosing which chains are most likely to succeed and fit with the regional strengths. Linking SMEs into these chains is vital for their growth to a significant scale. There is also evidence that competition is no longer company against company, but rather supply chain against supply chain (Fung, Fung and Wind, 2007).

Local business environment initiatives such as opening up procurement to become accessible to SMEs are also important. Such institutional innovations reduce transaction costs and encourage collaboration which can scale up local businesses and adjust the structure of competition. Other evidence can be found in the recent Chinese success which has built on the East Asian model of facilitating government where institutional innovation has linked supply chain into government policy and city design.

Monitoring and evaluation of the business environment has been shown to deliver real learning that can inform regional policy choices. Drawing lessons from policy innovations, looking for selective and narrowly targeted reforms, can develop stronger networks, markets and adaptive systems.

There is now an increased understanding that the economy can be seen as adaptive social and economic networks that link economic actors together in a flow of exchange (see for example Zukerman, 2003; McQuade and Butos, 2009).

Creating a general business environment that is adaptive and allows a series of conjoined initiatives to be woven tightly into the fabric of the regional economy presents a favourable framework for growth.

It is widely accepted that collaborative behaviours among the economic actors in a region provides the best route for increased efficiency and effectiveness to the whole social-economic system. Effective policies to enhance SME competitiveness need to address the way the region functions as a whole; this requires effective and efficient relations between different levels of government and 
associations to improve public service delivery and drive improvements in performance internationally.

\section{Context of Lombardy Region}

In terms of governance structures, Italy has gone through a significant decentralisation process since the 1990s and now has a three-tier system of sub national governments with 20 regions, 107 provinces and 8100 municipalities all with degrees of statutory autonomy. The most important role is at regional level which controls health services, urban planning, vocational training, culture and tourism, regional public transportation, environment, housing.

There are many actors in the economic system and a plethora of support agencies and associations. This creates a landscape for SMEs that can be confusing with a perception of scattered and overlapping initiatives. When this occurs it is often accompanied with a lack of focus on change outcomes for net effect at regional level.

Some of these characteristics are evident in Lombardy. Like many regions across the OECD, Lombardy has yet to organise and mobilise the different actors into an inclusive framework that spurs growth and development. Governance development has not kept pace with economic development and global competitiveness challenges. As a consequence, there are issues of overlapping responsibilities, incomplete networks and underdeveloped assets.

There is considerable sub-regional diversity in SME economic activity in Lombardy. The province of Milan is home to multinational and financial companies, educational and health institutions and research centres. Varese, Como, Lecco, Monza e Brianza, Bergamo all have a strong manufacturing sector but also a high proportion of service employment. Lodi and Brescia feature both manufacturing and agriculture, while the province of Sondrio as well as the three provinces in the plains (Cremona, Pavia, and Mantua) have a strong agricultural sector.

Desk research reveals that multinational companies have a strong presence in the region but employ only a small proportion of the workforce (27\%), whereas SMEs dominate the local and regional economy. In 2009, there were 823268 companies employing more than 4.3 million people.

One of the main characteristics of the Lombardy economy is the small scale of firms. The past resilience of the small business activity has been based on continuous product improvements. With the openness of markets and truly global competition, there is an increasing requirement to compete at the higher value market segments and demonstrate an ability to innovate and internationalise. Policy improvements can stimulate this change and promoting networks is an essential part of the practical delivery process.

SMEs are flexible and can adapt quickly to create new value but scaling this up in a highly competitive global context is a new challenge for the region, especially as many SME owners near retirement with a slowdown in growth aspirations and without a clear succession or exit plan. A previous OECD study on Milan metropolitan area warned of the need for rapid action on two fronts, innovation and governance, and to this must be added key challenges of access to finance and internationalisation.

Competitiveness will depend on the capacity to draw resources together, focus and mobilise the region's resources around a shared development strategy for SMEs. As discussed in other chapters, this is a priority area for attention especially if the positive assets and strengths such as established clusters is to be maximised. 
Lombardy has SMEs covering a particularly diverse range of industries and the organisation of SME representation, through industry associations and other second tier entities, is also diverse. In some ways, these locally derived and culturally appropriate systems should create strength and this has been the case for many years. However with globalisation and the increased pace of change and all pervasive competitive pressures, stronger and more dynamic levels of inter-firm co-operation are vital.

There is a plethora of organisations in the private sector but the needs of local SMEs are often difficult to match other than by immediate short term assistance such as access to funding and an introductory change initiative in the top areas of priority, internationalisation and innovation. The supply of services to SMEs faces many challenges at a grass roots level to stimulate more sophisticated demand based around a fundamental understanding of the factors critical for sustainable success and growth. Reinforcing the key messages through policies that set the framework environment for business and encourage networking can assist and build around the SBA principles.

\section{SBA Principles: the importance of business networks, the strengths and linkages}

The SBA sets out guidelines aimed at promoting the small and medium sized enterprises' growth and to create a more favourable environment, in terms of legislation and bureaucracy, for the SMEs. It aims to reduce the bureaucratic hurdles which inhibit SME growth and development. This is especially important in Lombardy where there are more SMEs per capita than in other regions and countries.

There are ten principles of the SBA and while all are relevant, seven are of direct relevance. These are discussed given the situation in Lombardy.

\section{- P.1 Create an environment in which entrepreneurs and family businesses can thrive.}

This requires an open approach to encouraging entrepreneurship at all levels of society, through the schools education system, throughout business and community life and into further and higher education. National and local legislation should recognise the importance of entrepreneurship with positive incentives to start and grow businesses. The strong traditions of small business and tight social networks in Lombardy give the region an advantage in delivering this principle of the SBA as it fits well with the grain of traditional attitudes. The tax system gives incentives to businesses at different levels and other instruments such as investment incentives and innovation credits. Businesses require access to other resources and infrastructure including premises and skills so these factors must also become prominent in the regional policy incentives. Wider considerations on how business is perceived as a career choice and the social status require to be promoted positively and reinforced continuously through the media and case studies of how more successful businesses are being generated. Matters of succession within SMEs and especially family businesses are particular issues in regions such as Lombardy where narrow views can predominate and value is lost to the economy when business transfers or ceases as often happens. This requires closer attention given the structure of the regional economy which relies on SMEs and the risks surrounding no clear exit or succession planning.

\section{- P.3 Design rules according to the "Think Small First" principle.}

Awareness of the importance of small businesses is vital to the region. SMEs are the dominant business form in Lombardy and must not be disadvantaged by rules or systems which, for example, seek to secure value for money but can risk excluding SMEs from being able to compete with larger enterprises. Procurement and licensing institutions in Lombardy region, including the local authorities, do recognise the importance of this and there are active initiatives to promote the principle including PR and instruments that encourage SMEs to work together in accessing more opportunities to win 
business. Allied to EU funded measures, instruments and competitions require consortia to be formed to access funding and bid for contracts, some of which are split into lots to enable more SME access. This has many benefits beyond the contract itself including the exposure of decision makers to more SMEs, increasing recognition of their capabilities and opening access to additional services and supports such as training and development, marketing and leadership. All this supports the "Think Small First" concept however progress in many regions around Europe is slow in implementing this principle.

\section{- P.4 Make public administration responsive to SMEs}

As noted above there is progress with a number of pro-active measures in Lombardy to improve public administration recognition and responsiveness to SMEs. This often requires training and additional resources in the short term however this produces benefits in the long term and can assist SME growth and development. As SMEs become more aware of the potential for growth, they become more demanding customers and seek more sophisticated support services. Public administration must be ready for this and encourage it to happen faster in order to assist SME growth and sustained regional prosperity. Larger businesses have more power and resources and can be easier to deal with in terms of lower transaction costs and ability to make their case for assistance or access to services. Developing parity for SMEs and efficient systems requires more effort and recognition of the importance of SMEs to the Lombardy economy.

\section{- P.5 Adapt public policy tools to SME needs}

Many policy tools can have unintended consequences that operate against SMEs and impose additional costs or barriers to SME engagements. Where costs are involved such as meeting quality standards or additional training, public policy can provide incentives for SMEs to invest to attain the required standards and thus be better able to compete nationally and internationally. Specific agencies and initiatives in Lombardy are moving in this direction and 'SBALombardiaLAB'" encourages this as well as drawing SMEs into the forum to raise awareness of how public policy tools are adapting to meet their needs.

\section{- P.7 Help SME to benefit more from the opportunities offered by the single market}

As noted earlier, tendering for major contracts in the EU and other markets often sets high standards to qualify for consideration. Many SMEs are not in a position to reach these requirements on their own even when they are capable of delivering the required goods and services. Specific instruments including ERGON project have worked to encourage SMEs to come together and form consortia to access EU and global business opportunities.

These are small in number at present and with strategic development in key sectors of strength and greatest potential growth much more could be done to develop SMEs and assist them to access opportunities in the single market. This can also work to raise standards and ambition by having a deeper effect on SMEs and the perception of being international and innovative. Financial assistance as well as qualitative enhancements such as this can work together to improve ambition, performance and competitiveness of Lombardy businesses on a global scale.

$5 \quad$ SBALombardiaLAB is a permanent laboratory for the SBA of Lombardy. The project is promoted by Unioncamere Lombardia and Regione Lombardia. More information are available at: www.sbalombardialab.it. 


\section{- P.9 Enable SMEs to turn environmental changes into opportunities}

Environmental changes present major opportunities for SMEs. In specific sectors such as energy, waste treatment and environmental services major contracts can be won by SMEs if they are prepared to meet the requirements. This often involves meeting standards and obtaining certificates of quality and capability. Information must be disseminated to SMEs about these opportunities and followed up with incentives and assistance to enable them to meet the standards and compete for business opportunities. SBALombardiaLAB has been working to raise awareness and provide channels to access information and assistance. Other institutions in the region have also developed their approach to engage SMEs and strengthen the capabilities of Lombardy.

\section{- P.10 Encourage and support SMEs to benefit from the growth markets}

The economic crisis has highlighted the importance of competitiveness and the necessity to seek new market opportunities outside the region and the country. Lombardy has an impressive position in Italy as the leading export region. $70 \%$ of exports are to traditional markets and partner territories in the EU. However much of the growth in years ahead will come from emerging markets such as the BRIC countries (Brazil, Russia, India and China) and it is essential that SMEs in Lombardy are encouraged and supported to access the business prospects in such growth markets. SBALombardiaLAB and specific instruments and initiatives by agencies including the industry trade associations have begun to do this. Numerous initiatives have taken delegations of SMEs to visit potential buyers in other countries including missions to Russia and China.

It is clear that the regional and national Italian government has begun to address many of the underlying issues to be tackled by SMEs and how to assist through initiatives in key areas including access to finance credit, internationalisation and innovation. For some SMEs this will enable survival and for others it will lead to a more significant process of transition and development to a new level of international competitiveness.

The Italian government has recognised the need for a review of SBA and implementation actions, especially to develop a networking culture in the country and the regional dimension to the SBA implementation. This is being taken up at regional level by partner agencies in Lombardy where expenditures of over 73 million Euros was devoted to priorities in the three axes of intervention:

- Competitiveness of enterprises.

- Attractiveness and competitiveness of enterprises.

- Micro enterprise and handicrafts.

Priorities included innovation internationalisation and access to credit as well as the SBA principles. Continuing this will encourage positive changes in business culture that will be vital for future competitiveness and prosperity in the region.

\section{OECD survey evidence and analysis}

The recent OECD survey in Lombardy reveals a number of findings including evidence from the education sector, business organisations and the region. The responses indicate that:

- Enterprise Learning teaching materials are not used in schools and there is no knowledge of this. This is an important area that requires attention of cultural attitudes towards enterprise 
and starting a business are to be improved in the region. Schools and teachers have a massive influence on the attitudes and career choices of young people who are the future wealth creators.

- There is no teacher training in entrepreneurship as a competence, but plans in ISCED (International Standard Classification of Education,). Teacher awareness and attitudes are fundamental to encouraging enterprise in the region so resources must be increased to upskill and motivate teachers so that they can have a positive effect in pupils.

- There is some cooperation between schools and enterprises, including company visits. This shows some networking which is good but there is scope for a more strategic and coordinated plan of action to build mutual appreciation of the enterprise learning agenda and the importance of SMEs in Lombardy life.

- There is no awareness of school networking on entrepreneurship. The exchange of ideas and discussion between schools is important to spread knowledge and strengthen awareness of the issues, constantly having the topic of enterprise on the agenda and developing the capacity within schools to appreciate and promote enterprise.

- There is no agreed view on the existence if a strategy for SMEs. Despite the number of public sector and industry association initiatives and posts created to drive the SME agenda in Lombardy, it is clear that communication and engagement needs to be improved between different agencies and economic actors in the region.

- There is uncertainty and very different observations on other resources devoted to enterprise learning such as the existence of approved or planned budgets. This again reflects a lack of awareness or understanding of how the enterprise learning agenda is being taken forward and how resources are being planned and allocated. This makes practical action very difficult and lessens the impact of expenditures.

- There are some extremely different answers on measures to tackle informal economy and other measures such as the use of regulatory impact assessments. From the responses, the picture is patchy at best and certainly there is a lack of shared views on what is being done and how public policy tools can assist positive changes in the economic development process.

- There is considerable confusion and variation of responses on public private consultations. Consultation and engagement are vital to build momentum for change and to co-ordinate efforts in the region. The programme of consultations and their format is something that should be reviewed regularly to gather more feedback and evidence of effectiveness.

- There is no awareness of premises developed or available for start-ups. This could indicate a disconnect between different policy initiatives and a lack of appreciation of the importance of premises to meet the needs of new start businesses and their development requirements as they grow and expand.

Business organisations responses indicate:

- There is no information on businesses near retirement (80\%). 
- There is confusion and a wide spread of responses to the basic question about a SME strategy in existence: $20 \%$ said no or definitely yes and pro-active while $13 \%$ did not know.

- Despite this confusion (or part of it) $80 \%$ of respondents said they had been involved in the strategy development process.

- No one is sure what the results of an Enterprise Learning strategy have been to date.

- Almost half see public private consultations as sporadic rather than regular and a further $13 \%$ don't know.

- There is a wide range of views on the influence of public private consultations with $20 \%$ saying they are unstructured debates and a further $20 \%$ don't know.

- There is awareness that information is made available and involves a wide range of companies.

- There is a wide spread of responses on the awareness of SMEs in the media.

- Confusion exists around whether there are tailored start-up services for university graduates, young researchers and employees in the territory.

- Responses indicate that SMEs in the territory have difficulties in accessing services and improving take up.

- All provide advisory and support services for internationalisation for SMEs in the territory and encouraging forms of networking.

- There are no SME internationalisation assistance schemes through coaching by large companies initiatives, which are available for SMEs (69\%).

The survey is not scientific but it does provide evidence of views from different regional actors and demonstrates considerable confusion about the business environment and assistance to promote enterprise and SMEs. It confirms the extent of further work that is required in the region to implement the SBA principles in practice and to communicate consistently and regularly.

\section{Challenges and opportunities}

\section{Strengths}

- Economic output: Lombardy remains one of the most competitive regions in Europe according to output figures/regional GDP contribution.

- Employment levels remain high for males and there is low unemployment: the industrial structure and plethora of SMEs with competitive strengths has created a buoyant labour market with defined sector clusters and the growing strength of Milan has attracted firms and commuter workers from across northern Italy, especially in the service sector.

- Higher education and vocational education: this remains strong with impressive performance of institutes attracting many international students and research funding. The vocational 
education system caters for the needs of many SMEs and maintains the sustainability of many local employers and communities.

- Stock and diversity of SMEs and sectors.

- Traditional quality and local supply chains.

- Industry associations, the Region and Chambers of Commerce: the agencies increasingly cooperate and promote a range of initiatives such as SBALombardiaLAB to improve the business environment and provide incentives to SMEs and others. The agencies support the entrepreneurial system by providing financial aids to improve competitiveness and bring businesses together to form networks and consortia for joint tender bids. This encourages further networking, collaboration, international development and innovation.

- Specific assistance programmes: initiatives such as the Program Agreement Economic Development and Competitiveness of Lombardy contribute significant assistance (98 million Euros in 2011). Calls for tenders such as the Ergon programme to create business aggregations provided over 23 million Euros in 2011. Other funds are provided to support access to credit, international trade fair attendance, entrepreneurship skills development/training and unblocking credit. Much of this is processed electronically to reduce bureaucracy and improve efficiency of processes for SMEs.

\section{Weaknesses}

- Fragmented assistance: there has been a number of conjoined initiatives and expenditure under the three axes of intervention priorities involving various partners however the impact of these efforts is not yet apparent.

- Cluttered institutions and blurred borders of responsibility: there are many agencies and associations representing different regional interests. The rationale for this number of organisations is historical and while such tradition has strength and community of interest spirit, there is a need to promote a more unified economic development platform and framework. This could work to effect cultural change and develop cross sector networks which appear limited at present.

- Lack of prioritisation on SME policies: broad competitiveness measures and significant expenditures are allocated but there is little evidence of sophistication in prioritisation of SME policies. There is scope to develop more nuanced forms of assistance that stratifies interventions and targets specific goals with key groups such as high growth businesses.

- Narrow supply chains: the traditional sector groupings and product specialisation in a single sector or clusters limits networking and the positive effects from wider synergies which could strengthen and stretching the supply chains.

- Adult education: there is a need for increased dynamism in the development of skills and upgrading to meet the new challenges of global competitiveness. Continuous professional development, leadership and management development as well as re-training all require to be given prominence within the SME community to improve competitiveness conditions and the overall basis for entrepreneurship and business growth. 
- Marketing and soft skills: traditional sectors remain string and have global leadership in design, fashion and automotive sectors however more emphasis on the value of marketing and service innovations that can be exploited through networks could generate new and sustainable high value economic activity with global opportunities for growth.

- Foresight: future scanning networks and discussion to consider how the regional economy will be best positioned post crisis will smooth the adjustment process for the new economic conditions.

\section{Opportunities}

- Clusters: the region has powerful sectors and high value clusters that are capable of being developed further with incentives from the business environment and further networking to exchange knowledge, especially at the margins where sector synergies could offer opportunities for SMEs to exploit additional value.

- Regional diversity and basis for growth: Lombardy has a diverse industrial representation across production and services sectors, traditional and modern, which could be developed through networking by SMEs entering more markets where future growth prospects are good.

- Spillover effects: the activities of other organisations including larger companies and universities create opportunities for SMEs to network and for the business environment to further incentivise this through specific interventions instruments.

- HE and research spin outs: the rich stock of expertise, ideas, knowledge and networks in the HE sector could be linked more strongly with SMEs development and promoted with incentivises including tax breaks, vouchers and bespoke shared premises that will further develop networking.

- Gazelles: there are many areas where high growth start-ups and growth SMEs could be targeted for specific in-depth assistance, collaborations and new initiatives to promote faster growth and access to significant resources and networks; filling critical gaps in supply chains: this is linked to exploitation of the regional assets, sector and cluster strengths, inward investment and commercialisation from the HE sector.

- Develop key infrastructures and flagship projects of scale to publicise the favourable business environment in Lombardy.

- Incubators: there is scope for more incubators aligned to existing assets that are run more tightly rather than as real estate with occupancy criteria that are relaxed over time.

- Post crisis platforms and initiatives: the region is in a relatively strong position and this is the time to invest in creating the conditions for this strength to be enhanced when the crisis subsides further. Specific networking and scenario events such as Artisan 2010 could be expanded further to promote new ideas from young entrepreneurial talent.

- Links with large companies networks to raise growth aspirations, provide demonstration effects and enable SMEs to access new networks. 


\section{Threats}

- Global competition: other countries and regions are developing new strategies and incentives to promote the conditions for SME growth and challenge traditionally strong regions.

- Outdated structures and skills in SMEs: the pace of change is faster than ever and with the openness of the global economy, the region must ensure that industry structures, employment participation and skills are appropriate and competitive for global markets.

- Lack of succession planning, professional education and CPD in SMEs: the family business is traditional and many are identified with a single owner rather than a management team and identifiable successors. Thus when the owner retires, many businesses cease. Traditional SME family business culture and traditional networks can also stifle change and inhibit innovation.

- Funding and investment: entrepreneurs and SMEs face many challenges to access funds especially in the current economic and banking crisis.

- Complacency: as the economic crisis abates, an attitude may emerge where settling back into what is traditionally acceptable becomes a fall-back position rather than striving for excellence.

From this assessment a number of conclusions and recommendations can be suggested in preparation for addressing the main challenges and targeting priorities for action, roles and responsibilities.

\section{Conclusions and recommendations}

Italy and Lombardy is going through a process of economic transformation. The context for developments regionally and nationally is changing at a fast pace which places more pressure on local developments and the issues that shape competitiveness.

Facilitators of change play an important role in the transformation process and the acceleration of local developments. Creating a business friendly environment for SMEs is a critical requirement for enhancing the general competitiveness prospects for small firms. In Lombardy, many agencies and organisations are working with initiatives to improve the business environment. This is a positive process necessary to preserve the leadership of the region in terms of wealth creation, high value employment and exporting. Initiatives such as SBALombardiaLab and significant annual expenditure interventions through the three strategic pillars or axes of competitiveness also make a notable contribution. The direction and intention is all positive in promoting the conditions for SME growth and networking. This aligns with the implementation of the principles of the SBA. In particular there is evidence of initiatives that assist in the delivery of SBA Principles P4 - P10. This is summarised below together with some recommendations on further development actions:

- P1. Create an environment in which entrepreneurs and family businesses can thrive: there is a strong history of creative enterprise that has established a strong economic region but the pace of changes globally necessitate closer attention given the structure of the regional economy which relies on SMEs and the risks surrounding no clear exit or succession planning for future generations. 
- P3. Design rules according to the "Think Small First" principle: given the predominance of micro and small businesses in the region, this is a key consideration for Lombardy. Procurement and licensing institutions in Lombardy region, including the local authorities, do recognise the importance of this and there are active initiatives to promote the principle including PR and instruments that encourage SMEs to work together in accessing more opportunities to win business. However the strength of partnerships to endure beyond the period of the instrument assistance or single contract opportunities remains a challenge that requires consistent encouragement to enable small businesses to gain full access to the opportunities available.

- P4. Make public administration responsive to SMEs: there is progress with a number of proactive measures in Lombardy to improve public administration recognition and responsiveness to SMEs. Public administration must encourage SMEs to become more demanding customers and seek more sophisticated support services to assist SME growth and sustained regional prosperity.

- P5. Adapt public policy tools to SME needs: specific agencies and initiatives in Lombardy are moving in this direction and the SBALombardiaLAB initiative draws SMEs into the forum to raise awareness of how public policy tools are adapting to meet their needs. This can develop momentum and spark further changes that assist SMEs and the effectiveness of public policy tools.

- P7. Help SME to benefit more from the opportunities offered by the single market: Many SMEs are not in a position to reach these opportunities. Specific instruments including ERGON project have worked to encourage SMEs to come but these are small in number at present. Further strategic prioritisation in key sectors of strength and greatest potential growth could enable SMEs to access more opportunities in the single market.

- P9. Enable SMEs to turn environmental changes into opportunities: initiatives such as SBALombardiaLAB have been working to raise awareness and provide channels to access information and assistance. Other institutions in the region must continue to develop their approach to engage SMEs in specific sectors such as energy, waste treatment and environmental services where major contracts can be won by SMEs.

- P10. Encourage and support SMEs to benefit from the growth markets: competitiveness is a global concept which is creating opportunities in new emerging markets and many local SMEs could access new sources of revenue if the appropriate encouragement is maintained. Numerous initiatives have taken delegations of SMEs to visit potential buyers in other countries including missions to Russia and China and this should be expanded to promote internationalisation.

The business base and inter-firm networks have become powerful instruments for building local economic capacity, enabling regions to compete in the global marketplace. In this context, there is considerable scope for more action that further develops growth and dynamism in the Lombardy economy. Recommendations are suggested below.

\section{Actions consistent with the EC SBA review}

The focus for further actions in Lombardy should align with learning from other experiences of implementing the SBA as revealed in the findings from the European Commission review of the implementation of the SBA (February 2011). This review urged Member States to take action to 
improve efforts in a number of areas, some where Lombardy is already initiating action and others where further action could be taken. For example:

- Introducing a single contact point for SMEs and simplifying the obligations in implementation of "think small first".

- Facilitating SMEs' access to structural funds, especially to support the creation of networks of enterprises, with priority in the fields of environment and energy.

- Creating one-stop-shop where SMEs can apply for European funds, national and local.

- $\quad$ Facilitate further access of SMEs to public procurement (for example by dividing contracts into suitable lots and avoiding SMEs being penalised in the selection criteria).

- Use a single centralised web site for advertising opportunities including procurement function to "find a business partner" for the joint bid, subcontracting or other business opportunities.

- Further develop micro and family business support. This could assist growth and succession for business transfers to occur more easily with promotion of opportunities through online platforms. This would facilitate meetings between entrepreneurs for collaboration and growth as well as an exit route in finding potential buyers.

\section{Developing the economic power base of Lombardy}

SMEs are the bedrock of the regional economy and the generator of enormous economic and social power. The advantages can be developed further through the pillars and priorities being pursued by the region. The Lombardy reputation for entrepreneurship and networks of small dynamic manufacturing and service sector firms in areas around Milan and other locations must be developed with up to date evidence and using the principles of the SBA to inspire further change and improvements. Gathering this evidence to highlight where opportunities exist and how local players can collaborate to capture these is a clear area for action. Such action will provide an intelligence resource for growth that develops from the existing and emerging strengths in the regional economy. Specific industry foci and clusters can become new drivers of wealth and competitiveness to strengthen the economic power base of Lombardy through a positive business environment, the growth of SMEs and continuous networking.

\section{Gathering evidence of transformation and SME change effects}

Monitoring and evaluation evidence should be gathered regularly with analysis of the contribution of the business environment and SME networking to economic growth. These effects are often subtle as well as structural when driven by legislation, regulation and advice through the attraction of incentives. The changes take time to emerge as direct impacts but are essential parts of the transformation process. A process for gathering data and deeper qualitative effects such as confidence, curiosity and collaboration should be systematic and feed into a region wide debate on the direction and pace of change for future growth driven by SMEs.

The engagement process will become part of the dynamic and develop more sophisticated SME customers for intervention agencies as well as demonstrating the net effects over time rather than the general level benefits from activity based expenditures. This would pick up on the effectiveness of networking to promote: supply chain development initiatives and SME access to tendering 
opportunities; incentives and networking with universities and larger businesses; reductions in burdens and bureaucracy for SMEs; succession and transfer of businesses for future sustainability and growth.

\section{Encouraging global perspectives}

In addition, networking to encourage SMEs and entrepreneurs to target global opportunities is an area for focus and preparing for the post-crisis global economy. Many SMEs have a local product focus and lack an understanding of global value chains and their importance in competitiveness. Markets are global and it is forecast that the BRICS (Brazil, Russia, India, China and South Africa) will account for the majority of global GDP within the next 15 years but only a tiny percentage of micro and SMEs currently export to these markets. With around $70 \%$ of Lombardy exports going to EU and traditional trading markets there is a need to encourage more networking by SMEs to consider targeting new international markets.

Encouraging more networking between SMEs and large businesses, including multinational, could bring important benefits, consolidate clusters and produce positive knowledge and behaviour spillover effects into SMEs and the regional business environment. This would link well with other initiatives around innovation and internationalisation discussed in later chapters of this report.

At a regional level, benchmarking and sharing of experiences with other regions internationally would also develop additional platforms and networks to assist the business environment and networking for SMEs. This would also assist to identify what specific framework conditions are missing or require strengthening in Lombardy.

\section{Practical initiatives and engagement with SMEs}

Firms drive economic competitiveness however their performance, sustainability and growth is shaped by the resources and macroeconomic conditions in the region, including the policy and institutional environment and the quality of the business environment. Micro and SMEs face many challenges and barriers to growth and basic pressures to maintain production and service levels can inhibit greater sophistication and value add activities. Practical interventions can assist this and instruments for enterprise and cluster development can improve performance as well as deeper development of culture, enterprise linkages and network efficiencies. All this can be brought together in a way that improves competitiveness with a global perspective that places new values on innovation, internationalisation and networking.

Practical regional initiatives can be aligned with wider national and EU initiatives however it is vital to engage with local SMEs, directly as well as through the established networks including second level representative organisations who are active partners in delivering many initiatives. OECD surveys in Lombardy and elsewhere have shown that there is perceived limited opportunity for SMEs to participate in policy setting sessions. Part of the problem is related to a lack of understanding on SMEs however this can be overcome with more active promotion and engagement, discussion and local events on the ground. Such engagement can positively promote SBA related initiatives, improvements to the operating environment and the key regional priorities of innovation and internationalisation.

\section{Networking sustainable development opportunities in sectors}

Specific environmental oriented opportunities exist and an initiative could focus on assisting more SME development and sustainable business growth. This could encourage networking vertically and horizontally with design, service and manufacturing SMEs to pursue more sustainable business 
practices. Such a programme could have direct business benefits and move SMEs awareness on the value of accreditations such as ISO 14000 which could open market opportunities internationally and with multinational corporations in the region. Regular events and sharing of exemplars success stories could encourage more SMEs to pursue these opportunities. 


\section{CHAPTER 2: ENTREPRENEURSHIP AND SME WORKFORCE SKILLS}

\section{Introduction}

This chapter focuses on the issue of entrepreneurship and SME workforce skills (Chapter 3 also connects with the theme of entrepreneurship). It starts with a general policy analysis of the importance of the link between human capital and productivity and wages and also discussed the role of human capital in raising entrepreneurship levels. The next section focuses on the current situation in Italy generally, since much of the entrepreneurship data is only available at that level, and some of the main labour market trends in the Lombardy region. It then turns its attention on the regional policy environment, highlighting the nature of the higher education and the vocational education system, concentrating on the key policies and initiatives. This is followed by a discussion of the main challenges that the Lombardy region is currently facing, as well as the opportunities that can be utilised more effectively in relation to entrepreneurship and SME workforce skills. The next section identifies policy recommendations, such as the need for the region to place much greater emphasis on the development of a culture of entrepreneurship; the need to strengthen the VET initiatives underway; the need assist SMEs to access training opportunities and the need for a sharper focus on key, young target groups among other recommendations. Two international "learning models" are presented in Annex I, which illustrate what is being done in other regions to face-up to some of the entrepreneurship and SME workforce skill challenges highlighted in the chapter.

\section{Policy and good practice}

It has long been established that high levels of human capital lead to increased productivity as well as wages (Becker, 1964). This process has intensified with the advent of the knowledge economy, which places a premium on education, knowledge, skills, flexibility, etc. Both regions and educational institutions have a role to play in ensuring that the human capital of their respective catchment areas is well-placed to make the most of the process of globalisation, taking advantage of their particular specificities.

The role of human capital in stimulating entrepreneurship is less well-established but the evidence points to a broad focus, no merely on education and training, but also to age, experience, understanding, etc. combined with the individual's innate potential. What is clear though, is that investment by firms in their human capital does encourage entrepreneurship as well as innovation (Sevilir, 2006). A recent OECD report (Marchese M., and Potter J., 2010) on the issue concluded that:

“... the four labour market-related factors most critical to entrepreneurship appear to be: (1) higher education; (2) extensive work experience; (3) interaction with a variety of actors in the regional innovation system; and (4) openness to immigration."

A recent OECD report on skills and jobs (OECD, 2012) reinforces the increasing importance of skills, especially in the current economic and financial climate:

"Without adequate investment in skills..., technological progress does not translate into economic growth, and countries can no longer compete in an increasingly knowledge-based 
global society... In short, skills have become the global currency of $21^{\text {st }}$-century economies. But this "currency" can depreciate as the requirements of labour markets evolve and individuals lose the skills they do not use. For skills to retain their value, they must be continuously developed throughout life."

\section{SBA Principles: the importance of entrepreneurship and skills}

Thus, it is not surprising that the Small Business Act (SBA) zeroes in on the issue of entrepreneurship and SME workforce skills. A number of SBA principles touch upon the issues covered by this chapter (P4, P5, P7, P9 and P10), though principle 1 and 8 are particularly important:

- P.1 Create an environment in which entrepreneurs and family businesses can thrive.

As discussed in the preceding chapter, this requires encouraging entrepreneurship at all levels of society (education system, business and community life as well as higher education), and national and regional legislation should recognise and stimulate entrepreneurship through incentives to start and grow businesses. The Lombardy region has traditionally demonstrated a high level of entrepreneurship and is well-placed to continue the process of raising the bar. The tax system should provide positive incentives and other instruments such as investment incentives and innovation credits and/or vouchers; which the Lombardy region is seeking to implement. SMEs also need infrastructure such as incubation and other tools, which are also prominent in regional policy incentives. The issue of succession, especially as far as family businesses are concerned, is of particular importance in the region and some efforts are being made to ensure that the local economy does not suffer through business closure through lack of succession planning and proactive exit strategies (see Chapter 3).

- P.8 Promote the upgrading of skills and all forms of innovation.

Chapter 4 deals specifically with the issue of innovation. However, equally important is the extent to which the Lombardy region assists the process of human capital development generally and skills specifically. The region has a large number of higher education institutions which are increasingly paying attention to the need for close linkages with the SME sector and to ensuring that the curricula take into consideration the needs of the enterprise sector. Traditionally, however, Italian as well as Lombardy-based SMEs traditionally do not invested sufficiently in skills: only $32 \%$ of all enterprises train compared with 58\% in the EU and the participation rate in education and training in Italy is $6.4 \%$ versus the EU average of $12.6 \%$ (EC; SBA Factsheet: Italy 2010/1). In order for SMEs to become more productive, competitive and innovative, the educational and vocational training system must prioritise the needs of enterprises into consideration.

\section{Situation in Lombardy}

\section{Entrepreneurial perspectives}

The latest Global Entrepreneurship Monitor (GEM, 2009) for Italy shows that 35\% of the adult population believes they have the required knowledge and skills to become an entrepreneur against an average of innovation-drive economies of $39 \%$ but only $7 \%$ of the population is expecting to start a new business in the next three years, which is similar to other innovation-driven economies in Europe (GEM, 2008)

Furthermore, the GEM (2009) shows that the established entrepreneurs (6.5\% of the adult population) are similar to many other innovation-driven countries. It found that these established business owners are typically male (two and a half times higher prevalence than among women) and 
older than early-stage entrepreneurs (42\% aged 35-44), which is similar to France and Spain. As with early-stage entrepreneurs, established ones tend to be well-educated and in terms of their regional distribution, $52.8 \%$ come from the North, $17.6 \%$ from the Centre and 29.6\% from the South and the Islands. The northern regions display the greatest entrepreneurial vitality, with a ratio of established entrepreneurs to population size equal to 1.16 ( 0.91 in the central regions and 0.83 in southern regions, Sicily and Sardinia).

Skills seem to play a pivotal role in driving entrepreneurship, highlighting a relationship between formal education and entrepreneurship. The percentage of working age adults who received training in starting a business varied greatly from $48 \%$ in Finland to $13 \%$ in Israel, however, Italy is positioned towards the bottom, with $17 \%$ of the population receiving training in starting a business. In addition, experts feel that entrepreneurs need help with their plans before start-up (equal to the innovationdriven country average of 3.3). However, Italy scores worse than other innovation-driven countries with regard to "enough help available outside education system" (Italy scores 2.8, while the innovation-driven country average is 3.3) and with regard to "quality of entrepreneurship education and training at school" (Italy scores 1.8 , while the innovation-driven country average is 2.2 ). The quality of entrepreneurship education and training after school is perceived as being similar to other innovation-driven countries (Italy scores 2.8 , which is the same as the average for other similar countries).

A report published by the Ministry of Economic Development (2010), has highlighted a number of important indicators are the national level (Le iniziative a sostegno delle PMI in Italia e in Europa", Allegato 2, Rapporto 2010) compared to the average in the European countries in relation to key SBA indicators:

- The indexes in which Italy performs in line with the EU27 average include:

- "Entrepreneurship as an opportunity" (57 vs. 57.5 EU27);

- "Participation rate in entrepreneurship education" (32.9 vs. 32.3 EU27).

- The indexes where Italy performs better than the EU27 average include:

- "Propensity to work for oneself" (39 vs. 30.7 EU27);

- "Shares of enterprises with a high degree of growth" (8.1 vs. 4.3 EU27);

- "Enterprise survival rate" (74.7 vs. 70.9).

- The indexes in which Italy underperforms the EU27 average include:

- "Degree to which compulsory education has fostered an aptitude toward entrepreneurship" (41.1 vs. 52.8 EU27);

- "Index of total entrepreneurship activity" (4.6 vs. 5.9 EU27);

- "Index of female entrepreneurship activity" (2.8 vs. 3.8 EU27);

- "Birth rate of enterprises" (8.2 vs. 10.4 EU27);

- "Proportion of staff in SMEs with higher education level" (14 vs. 30.4 EU27). 


\section{Firm and labour market issues}

The Chapter covering New Enterprise Creation (see Chapter 3 of this publication) has set out the general issues in relation to the entrepreneurial profile in the Lombardy region itself, which echoes some of the themes highlighted above in relation to the country as a whole, compared with the EU27 average. The main issues in Lombardy include: the relatively high but declining density of firms, the heavy emphasis on micro and small enterprises, especially family-owned businesses, and the excess of firm deaths over births since 2007. Chapter 3 concludes that these issues call for a renewed focus by the region on the issue of developing a culture of entrepreneurship.

An OECD report on the Higher Education in Lombardy region (OECD, 2011) makes a number of additional points:

- With over 9.8 million inhabitants (ISTAT, 2010), it is the most populated region in Italy.

- The population growth in recent years has been attributed to foreign immigration, which accounts for $25 \%$ of Italy's documented immigrant population.

- The region has attracted over 0.9 million immigrants, representing almost $9 \%$ of the regional population is mainly concentrated in Milano (41\%), Bergamo (11.3\%) and Brescia (16.6\%). Young immigrants accounted for $14 \%$ of $18-25$ age group in 2009 , but is set to increase to almost a quarter $(24.3 \%)$ by 2030 .

- The region is undergoing a profound industrial shift towards services and knowledgeintensive activities, but retains a significant manufacturing sector, which is under pressure from global competition.

- In 2010, the Lombardy workforce was predominantly employed in the service sector (64\%). The manufacturing sector continues to employ a higher proportion of the regional workforce than Italy as a whole ( $33.5 \%$ vs. $27 \%)$.

- At the same time, however, the employment rate in high and medium tech manufacturing remains low at $10.9 \%$ (vs. for example Stuttgart (21.2\%) and Piedmont (12\%).

- Multinational companies have a strong presence but employ only $27 \%$ of the workforce.

- 823,268 companies (8.45 companies per 100 inhabitants) employed over 4.3 million people in 2009 .

- The unemployment rate in Lombardy has remained below the national average and that of Europe. In 2010, the Lombardy unemployment rate was around 5.6\%, compared to the national rate of $7.6 \%$.

- The regional employment rate remains at a low level is because of early retirement, reliance on informal workers and the fact that female participation is discouraged.

- The unemployment rate for the population under 30 years in Lombardy increased from $8.4 \%$ in 2008 to $12.1 \%$ in 2009.

- Based on 2008 data, Lombardy is ranked 85 out of 242 European regions in terms of the youth unemployment rate, aged 15-24. 
- The regional employment rate was at $65.1 \%$ in 2010 , about $74.2 \%$ for men and $55.8 \%$ for women. Female employment, albeit increasing in recent years, is below the EU average.

- The employment rate of highly educated older Italians is nearly three times higher than the rate of the less educated peers.

- In 2010 , only about $15.9 \%$ of population aged 25-64 years had tertiary education qualifications, which is considerably below the EU27 average of $25.9 \%$.

- The Lombardy region has experienced stagnation in labour productivity caused by low levels of educational attainment and entry of low skilled workers in the labour market.

- Although Lombardy has a high level of employees in high tech sectors, only a small portion have higher education levels, suggesting underinvestment in technology and technologically advanced human capital.

Discussions with the Lombardy labour Agency suggest that a number of other labour market characteristics are noteworthy. The introduction of high speed trains mean that Bologna and Turin and a mere hour's travel from Milan; this has dramatically altered the labour market dynamic, especially as far as technical, managerial and other professionals segments of the labour market are concerned. Moreover, although the unemployment rate continues to be quite low by comparison with the Italian average, it is increasing, not least because of the hidden unemployment caused by public subsidies to keep employees on the payroll in some estimated 50000 SMEs (see also Chapter 3).

The above analysis provides food for thought as far as Italy generally and Lombardy specifically are concerned (Chapter 3 provides more up-to-date information on unemployment, female unemployment, youth unemployment, firm birth and death rates, number of active enterprises, etc. which reinforce the points made above). From the point of view of entrepreneurship, education and training, the region cannot afford to rest on its laurels; its key competitors are unlikely to.

\section{Regional policy environment}

As reported elsewhere in this publication, the Lombardy region does recognise the importance of the SBA and nominated a "Mr SMEs", as well as initiating the SBALombardiaLab initiative. Lombardy's development approach is driven by the five year plan of the region, combined with annual plans which set-out the nature of the programme and budget. The strategic goals for 2012 include: internationalization; innovation; networking; attractiveness to international investors; and credit (Accordo di Programa 2012). It should be stressed that the State has exclusive legislative powers concerning primary, secondary and tertiary education but regions do have competences, including universities (within the framework set-out by the State, which regional legislation has to comply with) as well as vocational education, in particular for the creation of an integrated system of education and professional training (Lombardy Regional Law 19/2007). However, entrepreneurship, human capital and skills development only feature in general terms in the 2012 entrepreneurship programme. Specifically in relation to human capital, the following is planned:

- Actions for the attraction and qualification of human resources (through the intersection between supply and demand), support for centres of excellence for the production, processing and dissemination of knowledge, enhancement of cultural capital and technology (patents and know-how). 
- Training and attraction of talents in the cultural sphere and the formation of specific profiles for operators of parks and green areas, with a view to strengthening the quality of public space.

\section{Higher education}

A detailed OECD report (OECD, 2011) analysed the current situation and concluded that:

- Higher education in Lombardy (and Italy) is characterised by low educational attainment, which constitutes a barrier to increasing the knowledge intensity of jobs, up-scaling the activities of the SME sector, and fostering product and process innovations.

- Furthermore, low retention rates and long duration of studies in higher education result in high costs to the society, late entry to the labour market and a low level of efficiency of the university system.

- The percentage of 25-64 year olds with tertiary education qualifications was $15.9 \%$ in 2010 vs. $25.9 \%$ in the EU.

- Presently the number of entrants is decreasing, which is bringing along greater competition between universities in Italy and Lombardy.

- The public university system in Lombardy is characterised by a high dropout rate $(11.2 \%$ between the first and second year in 2007/8). While this is below the national average $(17.6 \%)$, the dropout in private universities $(6.5 \%)$ is about three times lower.

- Because students take a long time to complete their degrees, a significant proportion of university graduates in Lombardy are over the age of 30.

- Youth graduate unemployment in Lombardy is a structural problem which the current economic crisis has aggravated.

- Out of approximately 50000 graduates in 2008, only 10000 (or 20\%) received a stable work contract in 2008 and 2009, while another 20\% received no work opportunities at all. Sixty per cent received very short-term and precarious jobs with low salaries (EUR 700 and 1000). Ten per cent have only an internship (typically less than EUR 500 per month).

Universities can support the economy through entrepreneurship education that helps to create and develop entrepreneurial attitudes and traits that, for example, motivate students to start-up a firm, become self-employed and acquire the skills needed to successfully run and grow businesses. Lombardy universities are increasingly involved in entrepreneurship education through individual courses (e.g. Politecnico di Milano, Bergamo) and degrees for entrepreneurship, including specialised masters (e.g. Pavia, Bocconi School of Management, LIUC). All universities are involved in Business Plan Competitions and Idea to Product Awards such as the "Start Cup". Bocconi University has established a centre for research on entrepreneurship and entrepreneurs (see OECD, 2011).

However, there is scope for enhancing entrepreneurship education in the region since it is still limited in most higher education institutions and a small proportion of students benefit. Universities could enhance enterprise in many different ways, including establishment of more structured business incubation, spin-offs and spin-outs. 


\section{Vocational education}

In 2006 the Region created 31 centres (out of 115 in all) for higher professional and technical training/education (Poli Formativi) involving a wide spectrum of educational actors (high schools, professional training centres, universities) and the economic/social sector (enterprises, trade unions and associations). The aim was to improve labour market skills and develop short training courses to address needs by upgrading the skills of students and employees and re-skill the unemployed population. The training supplied focused on specific professional sectors demanded by the market, rather than being complementary to university level training (IReR, 2010). The main beneficiaries include: young people seeking skills to support the transition to work; employed and unemployed adults seeking new qualifications and skills; and entrepreneurs. It is important to evaluate the current vocational professional education in Lombardy so as to improve technical education better meet the needs of a dynamic labour market (OECD, 2011).

Furthermore, recognising the labour market needs, as well as the ageing society, the Lombardy also introduced Vocational Training Vouchers (VTV or Dote Formazione - see Box below) so as to improve access to the education and professional training system. These vouchers are part of a larger voucher system designed to establish a demand-driven education and training system. Among other issues, the VTV seeks to improve the access to training of traditionally under-represented groups, thus stimulating the population to acquire knowledge and skills so as to remain competitive in regional, Italian and European markets. As with the Poli Formativi, the VTV and the wider regional voucher system is in need of independent evaluation to assess impact (OECD, 2011), not least because of the significant public resources being invested in the system.

\section{Box 3. The Dote system}

In 2005, the Lombardy region embarked on a reform of the regional education, training and labour market system. The main tool is the so-called Dote, a mix of financial resources and services assigned to the citizens through a targeted voucher system. The Dote is based on the integration of different funds and legal instruments based on one process of registration, resource allocation and monitoring of results. The Dote includes:

- School vouchers (Dote Scuola, education up to the age of 18) support free choice of the school (public or private). Funds for school vouchers are assigned to students attending public or private schools (1 100) and accredited training institutes (130). In 2008/09, around 3 million vouchers were granted to 170000 students/pupils. Vouchers were used in 4,784 different entities including book shops, transport services, student canteens, travel agencies and municipalities.

- Vocational training vouchers (Dote Formazione) foster employability. The voucher allows for the use of a maximum of EUR 5000 per person within 12 months. With a budget of EUR 25 million in 2009, vouchers were given to 5000 beneficiaries for a total of 13798 courses. The number of training hours was over 3 million divided into: professional (57\%), basic (37\%), transversal $(5 \%)$ and managerial training (1\%).

- Labour vouchers (Dote Lavoro) support labour market integration, skills upgrading and entrepreneurship. In 2009, EUR 112 million was granted to 27000 beneficiaries that benefitted from services and financial incentives worth up to EUR 3000 per person.

Results from prior reforms have shown that the voucher system can respond to challenges such as: i) reintegrating people into the labour market; ii) improving the matching of training programmes with labour market needs (school-work process); iii) overcoming the skills shortages and sustaining innovation and the growth of the knowledge society; and iv) recognising informal learning. However, comprehensive assessment has yet to be made of the Dote system.

Source : OECD, 2011 
Lombardy faces a major challenge in relation to its ageing workforce and low labour market participation rate. This, combined with the rapidly changing skill requirements in working life, means that lifelong learning, skills up-grading and re-skilling, and flexible ways of learning are becoming increasingly important. Upgrading the skills of the adult population is affects the region's economic performance and productivity, since adult learners are generally less mobile than younger students. This target group typically comprises non-traditional learners, who generally seek to combine work and study, which means that flexible ways of provision need to be developed through work-based, elearning and distance education. However, Italy currently underperforms in respect to lifelong learning: only $6.2 \%$ of the adult population ( 25 to 64 years) took part in continuing education, as compared with the European average of $10.8 \%$ (OECD, 2011).

The argument has been made that adult-oriented VET remains underdeveloped in the Region. Although 10-20 years ago there was a strong supply by state-owned institutions (e.g. training centres for tourism, cookery, etc.) the decision was made to allow private market provision to develop, supported by public resources via public procurement. However, although substantial resources are available, they are not stable since the contracts last for a few years at a time. The private sector provision remains patchy and dependent on public funds which are under pressure as a result of the economic and financial global crises.

Another issue is the fact that Lombardy appears to lack a well-functioning system of recognition of prior learning, although examples abound as to how accreditation and recognition of the prior learning system can operate (OECD, 2011).

\section{Other}

A final issue of relevance relates to the SMEs themselves and their attitudes to education and training. The fact remains that Italian and Lombardy SMEs (which are mainly micro / small and family owned enterprises) are not inclined to educate and train their staff, except on-the-job in relation to specific technical issues. Formal or structured training is the exception rather than the rule in part because customised or third-party training is expensive and the volumes of staff involved make it hard to justify the outlay. Furthermore, the lack of a Human Resource Development capacity in such firms makes it hard to access education/training, even if the owner is open minded. Finally, the cultural background of the entrepreneurs or general managers especially in the manufacturing sector, assigns the Italian miracle to cleverness on the technical side, rather to organisation, management, finance, marketing, etc.

The loss of competitiveness since the 1980 and 1990s has thrown a spotlight on the issue of management and related competencies, rather than just the technical aspects. This resulted in a number of key laws in relation to VET:

- Law 388/2000 created the Interprofessional Funds by levying a compulsory contribution of $0.3 \%$ of the salary bill of all enterprises. There are 18 such funds, including the Fondo Dirigenti PMI (SME managers), Fondo Formazioni PMI (SME training), Fondimpresa, Fondo Professioni, etc.

- Law 236/93 finances company training plans, especially for micro enterprises and precarious / low qualified workers, through vouchers.

- Law 53/2000 finances individual training plans through vouchers. 
The above structures have had positive effects on the willingness of both large and small enterprises to invest in training and education of their workforce. Nevertheless, differences in behaviour and attitudes towards training and learning persist: $73 \%$ of large Italian enterprises engaged in training compared to $17 \%$ of micro enterprises, rising to $22 \%$ in companies with up to 50 employees (Consorzio Lavoro e Ambiente, Report on Training and Support Structures for Young SMEs in Italy, 2010). A recent OECD study (Destefanis, 2012) examined the obstacles and barriers to effective skills utilisation (based on a survey of firms located in Campania and Veneto) and found that:

- There were difficulties in finding technical skills among the labour force.

- There was low satisfaction with the availability of technical education and training.

- Firms devoted fairly little time to training and did not feel the need to invest in high performance work practices. The lack of training is surprising because a considerable amount of the resources from labour taxation (paid by both employers and workers) is earmarked to finance training activities (and remains largely unspent).

- Firms appeared wary of getting into formal partnership arrangements with the public sector. While they needed funding for $R \& D$ and innovation, they did not want to be tied down by commitments in relation to their activities.

Although the skills situation is improving for SMEs, the absorption rate is affected by the lack of time / HRD capacity to follow and access these funds. It is thus possible, indeed likely, that small firms and low skilled workers do not benefit from the subsidy, or not as much as larger enterprise and more skilled workers, resulting in inefficiency. It may also be inequitable since the levy is paid by all, small/large and skilled/unskilled, but some may benefit disproportionately. Although regional institutions such as business associations and chambers (e.g. Formaper) offer support to SMEs to draw down support from the Inter-professional Funds, there are 750000 active enterprises in the region. The time, effort, cost, complexity, bureaucracy, etc. mean that many fall between cracks and does not make full use of this important resource that they are paying for but may or may not be using. Lombardy would be well-advised to devote support to raising awareness and support SMEs to access and make good use of these funds, especially the smaller enterprises.

\section{OECD survey evidence and analysis}

The OECD survey of Lombardy highlights a number of findings worth highlighting:

- Entrepreneurial learning: such teaching materials are not used in schools and there is little knowledge of this despite its importance in influencing future generations of entrepreneurs. There is no teacher training in entrepreneurship as a competence although their awareness and attitudes are fundamental to encouraging enterprise in the region. There is some cooperation between schools and enterprises, including company visits and internships but no school networking on entrepreneurship. There is some confusion about the existence or otherwise of budgets for enterprise learning. Business organisations' responses indicate there is no information on businesses near retirement $(80 \%)$ and there is also great uncertainty about the results of Enterprise Learning to date.

- Upgrading skills: there is currently no intelligence on growth sectors in the economy, which is clearly an issue in terms of matching skills demand and supply. Furthermore, views are inconclusive regarding quality assurance / accreditation of SME training and on-line training for SMEs, with half of the respondents suggesting the latter does not exist. 
While the survey is not statistically representative, it does illustrate a number of views from different regional actors. These suggest that more could be done in relation to the development of a culture of entrepreneurship, as well as promoting skills among SMEs.

\section{Challenges and opportunities}

This section presents an overview of challenges and opportunities facing the region, as far as the interconnected issues of entrepreneurship and skills are concerned.

\section{Challenges}

The Lombardy region has attained a high level of development and standard of living. However, the evidence indicates that it cannot afford to rest on its laurels; even before the current deep economic and financial crises started, its economic foundations were already under threat from globalisation, resulting in major economic restructuring. Although the workforce is predominantly employed in the service sector (64\%), the manufacturing sector continues to employ a higher proportion of the regional workforce than Italy as a whole $(33.5 \%$ vs. $27 \%)$. The industrial shift towards services and knowledge-intensive activities is set to continue.

Moreover, the demographic situation is far from satisfactory and the ageing structure will progressively impact the labour market. The unemployment rate is rising and will continue on an upward trajectory for the foreseeable future. Female participation rates are low and youth unemployment is rising steadily; female youngsters exhibit the highest levels of unemployment in the region. Meanwhile, the number of immigrants has reached close to 1 million and is set to increase, especially the young.

The population of the northern regions of Italy has a higher propensity to become entrepreneurs but as stressed elsewhere in this publication (see Chapter 3), the number of enterprises and density of firms are decreasing and the average firm birth rate has not exceeded the death rate since 2007.

The region has witnessed stagnating levels labour productivity, which are caused by low levels of educational attainment and entry of low skilled workers in the labour market. Although the region employs many in high tech sectors, only a small albeit increasing proportion have higher education levels. Both issues suggest underinvestment in technology and technologically advanced human capital, which will impact the future levels of competitiveness and innovation.

Although the region has the largest number of higher education institutions in the country, it exhibits serious weaknesses: low retention rates, long courses and low educational attainment at a point in time when the knowledge economy calls for flexible and knowledge intensity labour force, able to foster product, service and process innovation. Moreover, although there is some emphasis on entrepreneurial learning and skills, scope exists to enhance this, including generating smoother progression from the vocational training system to higher education. Moreover, the infrastructure for supporting skills development, linkage between research institutions and SMEs, mobility between academia and the private sector (and vice versa) could be enhanced.

\section{Opportunities}

While only $7 \%$ of Italians expect to start a new business in the next three years, $35 \%$ believes they have the knowledge and skills required to become an entrepreneur. But in terms of the regional distribution, $52.8 \%$ come from the North, which also displays the greatest entrepreneurial vitality, with 
a ratio of established entrepreneurs to population size equal to 1.16. This suggests that there is potential to raise the region's levels of entrepreneurship.

There is evidence that SMEs, despite being relatively small, self-employed and family run, are increasingly aware of and willing to invest in education and training in order to build-up the human capital of management and workers, though Italian firms perform well below the EU average in this respect. The advent of reforms such as (Law 388/2000, Law 236/93 and Law 53/2000) have greatly contributed to the process through the establishment of the Interprofessional Funds (e.g. Fondo Dirigenti PMI for SME managers and Fondo Formazioni PMI for SME training), company and individual training plans, partly through vocational training vouchers. However, much more effort needs to be made to assist SMEs, especially the smaller enterprises, to maximise access and use of these initiatives so as to boost levels of competitiveness and innovation at a time of sharpening global pressure.

The region is responsible for VET and it has taken this responsibility seriously through initiatives such as the Poli Formativi (covering 31 out of 115 institutions) and the Dote system. Both are large scale experiments which have been running for some time. It is now essential for the region to maximise the potential by evaluating and further strengthening the system, thus further boosting the quality of vocational training.

In Italy, the 25-34 years age group has the highest prevalence rate in Italy for early-stage entrepreneurial activity (42.5\%); with decreases with age (30.7\% for 35-44; $15.6 \% 45-54$ and $4.4 \%$ for 55-64). But while the desire to start a business tends to decline with age, skills and experience tend to increase. At the same time, established entrepreneurs tend to be slightly older: the 35-44 age group accounts for $41.4 \%$ of the established entrepreneurs, followed by the $45-54$ age group (30.1\%), the 5564 age group (13.3\%) and 18-24 group (1.9\%). This provides information with which to better target regional start-up programmes (see Chapter 2).

The ratio of female to male participation varies considerably in each phase, reflecting different culture and customs regarding female participation in economic activity. In innovation-driven countries, men are generally twice as likely to be involved in early-stage entrepreneurial activity as women (though this ratio is lower in countries such as Germany, Spain and USA). In Italy, however, the ratio is equal to 2.3 men for each woman among early-stage entrepreneurs. Furthermore, there are even fewer women among established entrepreneurs: the ratio ( 2.5 men for each woman) is one of the lowest among GEM countries. This too, provides significant potential for Italy and Lombardy generally.

Lombardy has drawn about $25 \%$ of all registered immigrants in Italy. Furthermore, they constitute $14 \%$ of the $18-25$ age group and are projected to increase significantly to almost $25 \%$ by 2030. International evidence stresses the entrepreneurial dynamism of this particular group, reinforced by local discussions with regional stakeholders in relation to the economy generally and Milan specifically. The challenge and at the same time the opportunity for the region will be to develop mechanisms to provide the necessary education, training, employment and entrepreneurship opportunities for this target group.

\section{Conclusions and recommendations}

An OECD report (OECD, 2012a) stresses the increasing importance of skills:

"Skills have become the global currency of 21 st-century economies... Getting the best returns on investment in skills requires the ability to assess the quality and quantity of the 
skills available in the population ..., determine and anticipate the skills required in the labour market, and develop and use those skills effectively in better jobs that lead to better lives. Working towards achieving this is everyone's business. Governments, employers, employees, parents and students need to establish effective and equitable arrangements as to who pays for what, when and how."

The Lombardy region has achieved a high level of development and the infrastructure for SME development, including entrepreneurship learning and skills development (including vocational educational training) are basically in place. However, the reality is that the industrial restructuring of the region is proceeding apace and the education and training system is struggling to ensure an effective match between the labour skills demanded and what is being supplied. Competing European and other regions do not stand still; Lombardy will need to react to ensure that it maintains its still advantageous economic position.

Thus both in terms of entrepreneurship and SME workforce skills, the region is meeting the objectives of the SBA. The key principles that touch upon these issues are Principle 1 and 8:

- P1. Create an environment in which entrepreneurs and family businesses can thrive: the region is generally entrepreneurial (see also Chapter 2 on New Enterprise Creation), though more could be done in the area of entrepreneurship learning and preparation at all levels of the education and skills development system.

- P8. Promote the upgrading of skills and all forms of innovation: the general skills environment, including vocational educational one, is in the process of being reformed. Much needs to be done to evaluate and further develop it, for example the Poli Formativi and the Dote Formazione systems. SMEs must be encouraged to make full use of all the opportunities available to raise their human capital, so as to enhance management, competitiveness and innovation levels.

At the same time, the foregoing analysis has demonstrated that more could be done to support entrepreneurship and SME workforce skills development, thus contributing to the development of a policy, programme and institutional framework for SME development. Below, we present a set of recommendations for consideration by the region.

\section{Renewed emphasis on a culture of entrepreneurship}

Italy's share of the population receiving voluntary or compulsory training to start a new business is significantly below that of other nations. The potential entrepreneur's human capital (in the form of education, experience and skills) are a critical resource endowment, which is fundamental to a new venture's success and growth potential, especially post-secondary entrepreneurship education and training. The aims should be to design study programmes that develop students' ability to recognize valuable opportunities and provide students with more useful knowledge targeting the abilities needed to start a new business. Although most students will not start new firms immediately after graduation, entrepreneurship training can have a life-long effect on their entrepreneurial alertness and motivation (GEM, 2009).

Although Lombardy has a high ratio of businesses to population, the density of enterprises does not automatically equate with entrepreneurship, just as being a businessman does not necessarily mean being entrepreneurial. The knowledge and skill-set required of entrepreneurs varies in time and space; a new generation of entrepreneurs, equipped for the modern era, is required. 
Whilst recognising the limits of the region's responsibility in relation to education, the region should review and strengthen the extent to which the educational system (primary schools, secondary schools, Vocational Education Training establishments, colleges and universities) enables aspects of entrepreneurship to be developed from primary through to tertiary education establishments. This can be done through initiatives to stimulate entrepreneurship: education and training through creative and experimental teaching methods that incorporate work, project and problem-based learning, and involve entrepreneurs as core teachers/coaches; practical experience of new venture formation provided to students; support for new firms in addition to spinoffs and start-ups. This process can be supplemented through awareness raising campaigns, entrepreneurial competitions at all levels of the education system, placements of teachers and/or student in industry, etc. thus stimulating the development of entrepreneurial skills and mentality, as well as preparing pupils and students for the modern labour market.

Prior to implementing this recommendation, it is essential for the Lombardy region to perform a stock-take of what is being done and where (primary schools, secondary schools, vocational education institutions / colleges and universities), combined with an assessment of European good practice, so as to develop a long term programme for implementation.

\section{Strengthen existing VET initiatives}

There are important initiatives underway which offer the potential to greatly strengthen the vocational education system, generate a better match between labour market skills demanded and supply and smooth the transition to higher level education. The key initiatives are the centres for higher professional and technical training/education (Poli Formativi involving a subset of the 115 institutions) and the vocational training vouchers (Dote Formazione) designed to foster employability. These initiatives involve significant levels of public funds, as well as a major commitment by the various stakeholders. It is essential for the region to independently evaluate the assess progress made and set out next steps in order to strengthen and mainstream these important initiatives.

\section{Maximise SMEs' Access to training opportunities}

SMEs, even micro enterprises, are increasingly aware of the importance of investing in education and training, so as to strengthen the human capital of management, technical staff as well as other specialist employees (marketing, PR, accounting, etc.). Developments such as the establishment of the Interprofessional Funds, especially Fondo Dirigenti PMI for SME managers and Fondo Formazioni $P M I$ for SME training, have greatly increased the scope invest in individual company / personal training plans, through vocational training vouchers. However, much more effort needs to be made to assist SMEs, especially the smaller ones. Employers are not satisfied with the supply of vocational training in Italy, not least because training curricula are bureaucratic and centralised. While they can use regional funding to adapt training to local needs, there is currently under-utilisation of training funds due to issues such as lack of flexibility in course design, existence of high transaction costs (i.e. red tape), lack of information about available funds, etc. (Destefanis, 2012). Due to a lack of knowledge, time, capacity and related factors, it is normally the larger enterprises that make the most of this opportunity; although micro and small firms pay into these schemes, they tend to underutilise them. It is essential for the region to raise awareness of the opportunities available and provide dedicated resources to assist, in particular the micro and small firms, to maximise access and use of these training and capacity building initiatives which assist in boosting the current levels of competitiveness and innovation at a time of intensifying levels of global competition. 


\section{Strengthen access to education and vocational training to key target groups}

The discussion in this and the related Creating New Enterprises Chapter (2) have highlighted a number of target groups that require further regional policy attention and programmes of support, namely:

- Youth (15-24): the unemployment rate was 5.8\% in 2011, but the youth unemployment rate was significantly higher $(20.7 \%)$; as with other EU countries, this is set of increase still further. In the case of Italy, the regional employment rate remains at a relatively low level due to early retirement, reliance on informal workers and underutilisation of women.

- Women (15-24) and more generally: the female unemployment rate (6.7\%) is higher than that of males (5.1; whereas the regional employment rate is $74.2 \%$ for men, it is only $55.8 \%$ for women. The highest unemployment rate in the region (25.3\%) is experienced by women in the 15-24 age group.

- Migrants (15-24): young migrants already make up about $14 \%$ of the in this particular group and the proportion is projected to increase to about $24 \%$ by 2030 . The capacities of the large immigrant population need to be raised over time. The current situation calls for a strong focus on this target group, which can only increase over time, if the labour market is to benefit fully from their potential input.

It is critical for the region to develop additional pathways, opportunities, programmes for all three target groups, especially in relation to the skills development.

\section{Other initiatives}

- Develop a well-functioning system of recognition of accreditation and recognition of the prior learning system (see also OECD, 2011).

- Develop initiatives aimed at SMEs for mid-level technical and professional personnel with experience in an industry on process and product/service. These would target innovationoriented degree/vocational certificate programmes.

- Develop initiatives targeting SME managers focusing on business, internationalisation, competitiveness, innovation, networking, etc.

There is a need for the region to promote the establishment of dedicated (re)training programmes for existing business people focusing on new business models and approaches, combining elements of local skills and strengths for competitiveness and innovation, and generally equipping those already in the labour market with new business concepts, tools and techniques for the modern era. Dedicated (re)training programmes could be established using existing institutions, such as university, research centres, training centres, etc. This recommendation is designed to counteract the fact that, although there is quite a high density of businesses, these tend to be traditional businesses, rather than technology / knowledge-based ones, an issue which is closely connected with the issue of innovation analysed in separate chapter of this report. 


\section{CHAPTER 3: NEW ENTERPRISE CREATION}

\section{Introduction}

This chapter concentrates on the theme of new enterprise creation, albeit with references to the issue of culture of entrepreneurship, since the two are interlinked (see also Chapter 2 of this publication). First, we present an analysis of the importance of entrepreneurship at national and regional levels, highlighting the principles contained in the Small business Act (SBA). The next section focuses on the current situation in the Lombardy region, concentrating on the current policies, institutions and infrastructure to support the creation of new enterprises. This is followed by a discussion of the main challenges that the Lombardy region is currently facing, as well as the opportunities that can be utilised more effectively, as far as entrepreneurship and start-ups are concerned. The next section identifies policy recommendations, concentrating on the need to focus more sharply on competitiveness and innovation; the need to review and improve SME programmes and infrastructure; the need to better integrate information and services for potential and actual entrepreneurs; and finally the need to maximise the full palette of entrepreneurial talent available in the region. Annex I includes an international "learning model" which illustrates what is being done in other regions to face-up to some of the entrepreneurship and new enterprise creation challenges highlighted in the chapter.

\section{Policy issues and role of EU}

Stimulating the establishment of new enterprises and, connected with this, developing a culture of entrepreneurship, have become increasingly important policy objectives (OECD, 1998). The European Commission (EC) "Entrepreneurship in Europe" Green Book (2003) first highlighted the importance of entrepreneurship generally. Entrepreneurship is regarded as a major driver of innovation, competitiveness and growth. Consequently, entrepreneurship is promoted and supported by the EC via a plethora of strategies, policies, programmes and funding regimes, not the least of which are the structural and cohesion funds, which focus on improving the entrepreneurial environment for start-ups and SMEs.

National, regional and indeed local level policy-makers increasingly recognise that they can play a role in relation to stimulating a culture of entrepreneurship and thus creating new enterprises. At the same time, it is clear that there are no ready-made policy solutions: each nation, region, city or municipality must experiment in order to develop the appropriate recipe for its particular locality, taking into consideration its particular specificity, whether historical, cultural, social, economic and political heritage (OECD, 2009).

The European Union (EU) meeting in Lisbon (2000) set itself the ambitious goal of becoming the most competitive and dynamic knowledge-based economy in the world, capable of sustainable growth with more and better jobs and greater social cohesion by the year 2010. But by 2005 it was already apparent that the goal was overly ambitious, resulting in the revised Lisbon Strategy focusing on two tasks: stimulating lasting growth and creating more and better jobs. However, the on-set of current global financial and economic crises required a further rethink. The result was Europe 2020, a 10-year strategy designed to revive the European economy through "smart, sustainable and inclusive growth," 
with greater coordination of national and European policy. Five targets set to boost growth and employment (EU, 2010):

- Raise the employment rate of the population aged 20-64 from $69 \%$ to at least $75 \%$;

- Invest 3\% of GDP in R\&D by improving the conditions for R\&D investment by the private sector;

- Reduce greenhouse gas emissions by at least $20 \%$ compared to 1990 levels or by $30 \%$ if the conditions are right, increase the share of renewable energy in final energy consumption to $20 \%$, and achieve a $20 \%$ increase in energy efficiency;

- Reduce the share of early school leavers to $10 \%$ from the current $15 \%$ and increase the share of the population aged 30-34 having completed tertiary education from $31 \%$ to at least $40 \%$;

- Reduce the number of Europeans living below national poverty lines by $25 \%$, lifting 20 million people out of poverty.

Increased levels of innovation and competitiveness underlie the new Europe 2020 initiative. In turn, these require greater levels of entrepreneurship, improved business environments, especially for SMEs, and development of a strong and sustainable economic base, able to compete globally.

\section{SBA Principles: the importance of new enterprises}

The Small Business Act (SBA) emphasises new enterprise creation (start-ups) strongly. Almost all the SBA principles touch upon the issues covered by this chapter (especially P4; make public administration responsive to SMEs; P5: adapt public policy tools to SME needs; P6: facilitate SMEs' access to finance and develop appropriate legal and business environment; P7: help SMEs to benefit more from the opportunities offered by the single market; and P10: encourage and support SMEs to benefit from the growth markets). Each of these has already been discussed in the preceding chapter and will not be repeated. The most important Pillar, by far, is clearly P1, which emphasises creating an environment in which entrepreneurs and family businesses can thrive, including succession/management transfer as the founding entrepreneurs approach retirement.

\section{Situation in Lombardy}

This section examines the nature of entrepreneurship in the Lombardy region, such as the number of births and deaths of firms, as well as other factors such as the density of enterprises. This is followed by a brief analysis of the key institutions responsible for stimulating the creation of new enterprises. It leads to an analysis of the key challenges and opportunities facing the region.

\section{Entrepreneurship profile}

A few facts are sufficient to illustrate the importance of the Lombardy region to both the Italian and the EU economy:

- Lombardy is located at the heart of Europe; it is at the crossroads between the major EastWest communications routes (Iberian Peninsula and Balkans) and the North-South routes (continental Europe and Mediterranean. 
- It is the region with the highest concentration of people, as well as businesses and wealth. Lombardy represents about $16 \%$ of the overall national population with approximately 9.8 million inhabitants (ISTAT, 2010).

- Lombardy is one of the engines of the European economy, being one of the 26 richest regions within the EU and accounted for about 20.7\% of the Italian GDP in 2008.

- The 750000 (2011) Lombardy enterprises accounted for ca. or approximately $15 \%$ of the national total.

- About $40 \%$ of the Italian multinationals are Lombardy-based; and about 800 foreign and multinational companies have their headquarters in the region.

- Lombardy has experienced strong foreign immigration flows and is now the most diverse region in Italy, accounting of $25 \%$ of the country's documented immigrant population (see also Chapter 2).

While the above paints a very positive picture of the Lombardy economy, the reality is that the global financial crisis and economic recession have had a tremendous impact (in 2008, the per capita GDP in Lombardy decreased to the level of 2000, even though the absolute GDP grew from EUR 246 billion to EUR 326 billion); the region faces serious challenges to maintaining its competitiveness.

The unemployment rate has risen steeply since the period prior to the crisis: whereas in 2007 the unemployment rate stood at $3.4 \%$, this increased to $5.8 \%$ in 2011 . This compares favourably with $9.8 \%$ in Italy as a whole (ISTAT, March 2012) but the relatively low unemployment rate, one of the lowest in Italy, hides significant variations. The female unemployment rate $(6.7 \%)$ is higher than male (5.1\%) but the youth unemployment rate (15-24 year olds) is significantly higher (20.7\%) and highest of all (25.3\%) for women in the same age group. While this represents a relatively positive situation in the region compared with Italy as a whole and certainly compared with the EU27 average $(9.9 \%$, March 2011), the regional employment rate remains at a relatively low level due to early retirement, reliance on informal workers and the fact that the Lombardy labour markets do not encourage female participation. The regional employment rate was at $65.1 \%$ in 2010 or $74.2 \%$ for men and $55.8 \%$ for women. Female employment, albeit increasing, is below the average European levels. Discussions locally suggest that the statistical picture may be overly positive: an estimated 50000 SMEs continue to use state/regional subsidies to maintain employees on their payroll, rather than initiate programmes of layoffs. In 2011, 12.5\% of the labour force were graduates; the employment rate of highly educated older Italians is nearly three times higher than the rate of the less educated peers (OECD, 2011).

Turning to the regional business demographics, the number of registered enterprises was 834820 in 2007, however, the global recession has caught-up with the region, resulting is a decrease to 751 638 enterprises by 2011 (source: Infocamere), a process which is almost certainly certain to continue for the foreseeable future. Turning to the birth and death rates, Graph 1 shows that since 2007, there have been systematically more deaths than births, with the exception of 2010 . 
Figure 3. Business Birth and Death Rates in Lombardy (2002-2011)

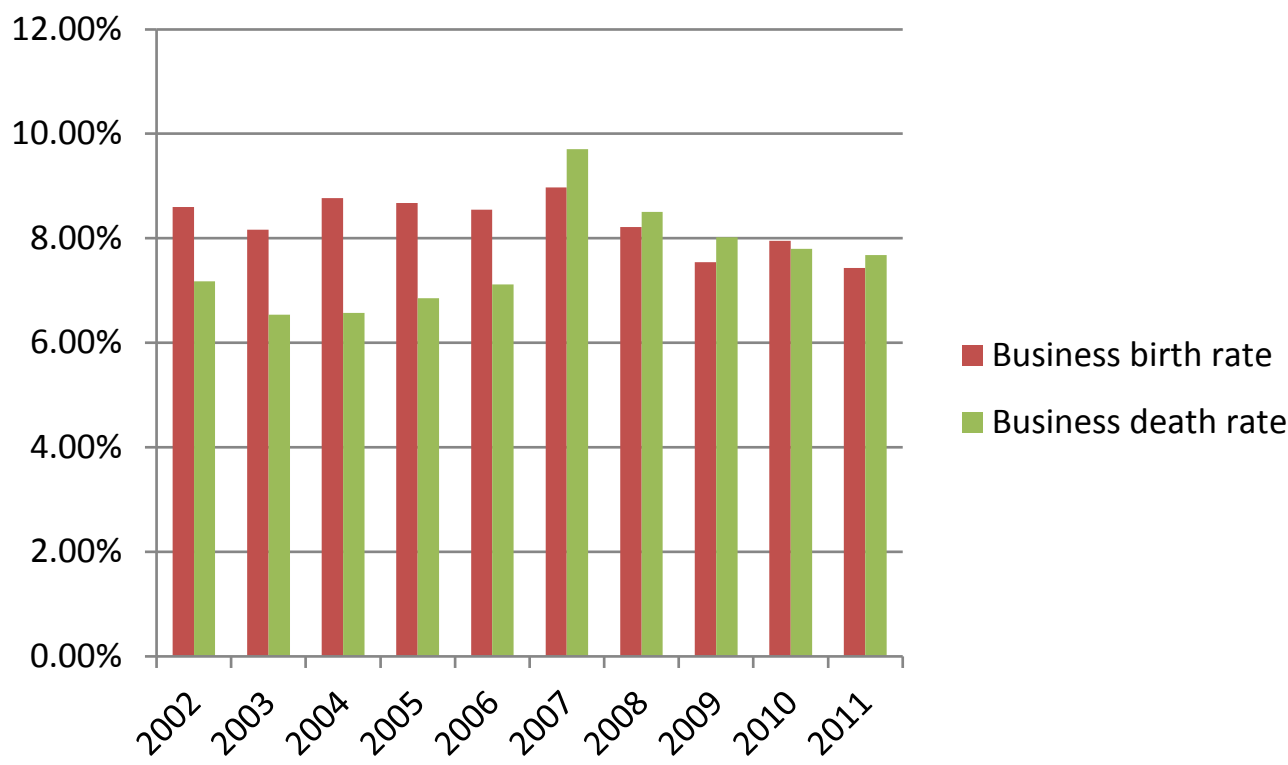

Source: Registro Imprese, Infocamere

While the level of business density remains at a high level compared with the EU average, it is in decline. Whereas in 2002 there was 74.49 enterprises per capita, according to the latest data by 2010 it stood at 71.93 (ISTAT, ASIA - Struttura e dimensione delle unità locali delle imprese). A firm-size analysis shows that the Lombardy economy is heavily biased towards micro and small enterprises, a trend which is not changing over time (see Table 1).

Table 1. Size of Lombardy Enterprises (1999-2010)

\begin{tabular}{lllllllllllll}
\hline & 1999 & 2000 & 2001 & 2002 & 2003 & 2004 & 2005 & 2006 & 2007 & 2008 & 2009 & 2010 \\
\hline $1-9$ & 93.64 & 93.74 & 93.81 & 93.82 & 93.6 & 93.67 & 93.72 & 93.73 & 93.69 & $93.56 \%$ & $93.76 \%$ & $93.91 \%$ \\
$10-49$ & 5.54 & 5.41 & 5.32 & 5.3 & 5.51 & 5.45 & 5.41 & 5.39 & 5.43 & $5.56 \%$ & $5.37 \%$ & $5.24 \%$ \\
+50 & 0.82 & 0.85 & 0.87 & 0.87 & 0.89 & 0.88 & 0.87 & 0.88 & 0.88 & $0.88 \%$ & $0.87 \%$ & $0.85 \%$ \\
\hline \multicolumn{7}{l}{ Source: Istat (2011) }
\end{tabular}

Regional data also sheds light on the nature of enterprise owners in Lombardy ( $4^{\text {th }}$ quarter 2011 , info provided by the Region to expert team):

- Female entrepreneurs: there were 172582 active enterprises owned by women (20.9\% of all active enterprises) concentrated in the wholesale and retail trade $(26.9 \%)$; other services $(11.3 \%)$ and manufacturing (10.8\%) sectors. Young enterprises: there were 88,213 active young enterprises $(10.7 \%$ of all active enterprises) concentrated in the Buildings (27.8\%); wholesale and retail trade, repair $(22.4 \%)$ and accommodation and food service $(9.1 \%)$ sectors. Foreign enterprises: there were 77,466 active foreign enterprises (9.4\% of all active enterprises) concentrated in the buildings (34.9\%); wholesale and retail trade, repair $(25.7 \%)$ and accommodation and food service $(9.2 \%)$ sectors. 


\section{Regional policy environment}

Lombardy's development approach is driven by the Regional Development Programme (Programma Regionale di Sviluppo 2010-2015), which sets out three main planning areas, namely the Economic Area (Lombardy for knowledge and smart growth), the Social Area (Lombardy for welfare of responsibility and inclusive growth), and the Territorial Area (Lombardy for resources and sustainable growth). This is combined with annual plans which set-out the nature of the programme and budget. The strategic goals for 2012 include the following: internationalization; innovation; networking; attractiveness to international investors; and credit (Accordo di Programa 2012). The region stresses that SMEs are at the forefront of its economic programme, as illustrated by the resources spent on enterprise support. In terms of SBA itself, the region recognises the importance of the 10 SBA Pillars contained within it and anticipates that the SBA review in future will reach down to the regions. It has two main initiatives specifically in relation to the SBA:

- Mr SMEs: this is, at the same time, the region's Director of the General Direction Industry, Handicrafts and Construction and Cooperation and is responsible for all SME policies in the region. There is a feeling the Mr SME/Director roles are interchangeable and that the $\mathrm{Mr}$ SME role may make less sense at the regional than national level, since the capacity to affect the legislative environment is limited. Nevertheless creation of a Mr SME role sends out a message to stakeholders that the region both recognises the importance of SMEs and is committed to supporting them.

- SBALombardiaLab: this initiative has several elements, including seeking to benchmark the region (a process to which this report contributes) and producing a Position Paper presenting recommendations to policy makers in Italy as well as EU, focusing on issues such as access to finance, internationalisation, process and product Innovation, start-ups and access to EU funding.

\section{Regional SME institutions}

The main institution responsible for SME development in the region is the General Direction Industry, Handicrafts and Construction and Cooperation. This comprises approximately 100 staff in three departments:

- Competitiveness: dealing with R\&D, innovation, internationalisation, etc.

- Entrepreneurship: dealing with financial policies, start-ups, construction, etc.

- Funds: dealing with issues connected with management of funds.

The General Direction Industry, Handicrafts and Construction and Cooperation focuses on:

- Networking of enterprises: to help SMEs to work together through clusters and value chains; enabling "contamination" between enterprises.

- Innovation policies: a focus on 10 strategic sectors such as: aerospace, ICT, biotech, design, renewable energies, new materials, green construction, etc.

- Rationalisation of financial policies: a focus on simplification and sustainability of credit guarantee schemes. 
- Attractiveness: a focus on attracting Foreign Direct Investment (FDI), etc.

However, because SMEs are considered to be at the forefront of policy-making in the region, the General Direction does not have a strategy or action plan per se. The view is that since SMEs cover over $99 \%$ of the region's enterprises, this is not necessary.

\section{Regional programmes}

The region has developed a palette of activities to support SMEs. For example, under the 2012 programme, the General Direction highlighted the following activities:

- A new regional law on SME development.

- A focus on internationalisation.

- A focus on networking of enterprises.

- A focus on rationalisation of credit guarantee schemes.

- A focus on innovation and competitiveness, including voucher schemes.

- A focus on new investment, including Foreign Direct Investment (FDI).

Turning specifically to new enterprise creation, there are two main programmes, as well as other support initiatives:

- Start-ups: this programme mainly targets young people, women and disadvantaged workers in recognition that it is very difficult to start-up a firm, especially by young people. The region's main focus in on the 30-35 age group since it does not necessarily support micro enterprises; rather, the emphasis is on "real companies" of a substantive nature employing a number of people. The programme is significant (Euro 30 million) and includes a revolving fund. It is expected to invest an average of Euro 50000 per enterprise (zero interest, repayable over 7 years) in some 400-500 new firms. The region is looking to integrate other programmes, both regional and from partners such as the Chambers of Commerce, universities and research institutions. Based on the regional data, most support (80\%) is directed at the service sector (retail, tourism, etc.) and the remainder to industry, including $6 \%$ to the manufacturing sector. The regional monitoring data show that the within one year of the investment, the average number of employees is 6 but there does not appear to be information on the additionality issue, survivability rates, etc. But $9 \%$ are known to be experiencing repayment difficulties. Of the target 400-500 investments, about 150 have been approved, with the rest pending. The Start-ups programme is a follow-up of an earlier programme which operated during 2000-2011 but it is curious that such a longstanding programme was not independently evaluated. This should not be the case for the Start-up programme, given the level of public funding involved as well as the usual concerns over additionality, dead-weight, displacement, etc. which affect this type of initiative.

- Start: is also supporting start-ups (target: 2000 new firms) in the form of training and financial support (involving Lombardy region, EU, Chamber of Commerce). Training is a key component (2 000 young people, 5000 others) and applicants cannot receive funds without participating in the training. Start is the successor of programme called Saturno (Euro 23 million 2002-2007). According to discussions, the evaluation of Saturno reportedly 
showed that 10000 people were trained and 2000 new firms were created but no information appears to be available on the impact in terms of additionality, sustainability, etc. Start involves less money (Euro 6-7 million) but more targeting and support. In 20112 000 potential applicants participated in the information sessions, of which 500 applied to do the training courses. Those that attended $75 \%$ of the course had the option of presenting a business plan; requesting up to Euro 10000 (those up to 35 years of age) or Euro 5000 (those over 35 years of age). Other assistance includes telephone support for one year after initiation of activities. Only 150 new enterprises were generated in 2011 (the mortality rate is not known); the targeted number of start-ups in 2012 is 200.

- Activities linking with start-ups: In addition to the above two programmes, a number of activities have resulted in support infrastructure which connects with the issue of creating new enterprises, such as business incubators, clusters and technology and science parts. The Box below represents an overview of some of the infrastructure in the region but is not comprehensive, since the region lacks an up-to-date database of all such instruments in the region (see Box below).

\section{Box 4. SME infrastructure In the Lombardy Region}

There are 23 structures (universities, private firms, social companies, chamber of commerce special agencies, consortia, technology and science parks) which provide, among others, services to start-ups. Although not all host start-ups in their premises, they do assist firms in their early stages of growth with consultancy, administrative or fiscal services, networking, grant applications, etc. This is the infrastructure that has been validated by the regional government (Ėupolis) and are thus able to apply and use regional funds. A further 35 structures with similar features are known to exist but are not / yet validated by the region.

Technology and science parks

- Science Park Raf (www.spr.it)

- $\quad$ Servitec (www.servitec.it)

- Kilometro Rosso (www.kilometrorosso.com)

- Parco Tecnologico Padano (www.tecnoparco.org)

- Polo Tecnologico Milano Bicocca (www.pirellirealestate.com)

- ComoNEXT (www.comonext.it)

Business incubators

- $\quad$ Science Park Raf (www.spr.it)

- Point - Polo per l'innovazione tecnologica di Bergamo

- Kilometro Rosso (www.kilometrorosso.com)

- Parco Tecnologico Padano (www.tecnoparco.org)

Source : Italian Association of Scientific and Technological Parks (www.apsti.it) and regional information system (www.questio.it) 
Discussions with regional stakeholders suggest that the business incubators and start-up / venture capital funds may not yet be achieving the desired impact and expected sustainability. Although there are numerous clusters in the form of Industrial/Meta Districts, there appears to be some uncertainty about the role that they are expected to perform in the region and the appropriate form of policy support required. Other policy areas in need consideration include issues such as whether or not the region should develop programmes for firms with high growth potential ("gazelles"), whether there is a need for a sharper focus on cooperation with research institutions to further promote spin-offs and spin-outs, whether more could be made of female, young, 50+ and ethnic minority entrepreneurs and indeed, whether the existing programme to support inter-generational transfer of business could be rendered more effective.

\section{OECD survey evidence and analysis}

The OECD survey of Lombardy highlights a number of findings:

- Enterprise learning: discussed in the preceding Chapter.

- Succession and management transfer in enterprises: discussed in the preceding Chapter.

- Although 35\% indicated that that there is frequent mentioning and celebration of business startups in the local media and/or cultural life, the majority thought this could be enhanced still further.

- Respondents acknowledged that there are general business services for start-ups and that an increasing number of start-ups in the territory is utilising such services. This is reinforced by the fact that $87 \%$ provide such services to start-ups. The same applies to start-up training and business advisory services for start-ups and young companies.

- Premises for start-ups: there is no awareness of premises developed or available for start-ups (see also Chapter 1) but there is awareness of the existence of incubators, science parks and cluster to promote networking and innovative companies.

- Graduates and young researchers: confusion appears to exist around whether there are tailored start-up services for university graduates, young researchers and employees in the territory.

While the OECD survey may not be statistically representative, it does illustrate a number of points, such as of views from different regional actors and demonstrates considerable confusion about the business environment and assistance to promote enterprise and SMEs. It confirms the extent of further work that is required in the region to implement the SBA principles in practice and to communicate consistently and regularly

\section{Challenges and opportunities}

This section presents an overview of challenges and opportunities facing the region, as far as the interconnected issues of entrepreneurship and start-ups are concerned. The strengths of the region have already been discussed in the preceding analyses in this and other Chapters. However, it is important to stress that the region's most significant strengths include the continued concentration of population, enterprises and wealth in the area, including its strategic location in Europe. 


\section{Challenges}

The most pressing challenge is the necessity to cope with the rising levels of unemployment, including the relatively very high levels of youth unemployment, which have risen notably in recent years. The economic and financial crises are global in nature but affect European countries and regions in different ways. If anything, given the public debt crisis, the Eurozone crisis and the risk of sovereign default, it is likely that the situation in Italy will deteriorate before it improves, deeply affecting even relatively wealthy region such as Lombardy. The levels of unemployment, combined with the high death rates of firms (which have exceed firm births since 2007) require the region to support entrepreneurship / start-ups of all types (not simply those that have been located in the region longer than five years and innovative or those that create significant employment right from the beginning) and by all social groups, if it hopes to maximise the potential of the growing pools of idle human capital in the medium to long term. This is also reinforced by the results of the SBALombardiaLab focus group discussions which revealed concerns about support to both traditional and innovative start-ups (Internationalisation/Innovation/New Enterprises/ MSMEs and Europe, SBALombardiaLab, summary of focus group discussions).

The region needs to rediscover an emphasis on SMEs, including start-ups. It is not sufficient to argue that the region does not need a strategy as all of its policies are geared towards SMEs in one form or another. The fact is that regional resources are limited and need to be targeted effectively. It is not possible to "target" over $99 \%$ of all enterprises. It is important for the region to make explicit policy statements about what it will prioritise, what the targets will be, the timescale for implementation, the indicators of success and how the strategy with be monitored and evaluated.

Connected with the preceding discussion, there is a significant challenge to assess what works and what does not in relation to enterprise creation specifically and SME development generally. For example, the region remains unclear about how to develop clusters, whether business incubators are meetings their intended objectives, whether the start-up and venture capital funds are effective, how to restructure the credit guarantee schemes, etc. The region does not seem to know what exactly the infrastructure available is. This suggests that there is a need to reconsider its enterprise development policy, infrastructure, priorities etc., possibly connected with developing an explicit Competitiveness and Innovation Strategy (see preceding point). This would allow for a concerted effort to be made in relation to enterprise support.

The institutional environment in the region is dense - an extensive network of institutions, policies, programmes and projects exist. While this is potentially a source of regional strength, potential for overlaps and inefficiency in provision exists. These can (and probably do) result in confusion for the business sector (e.g. multiplicity of organisations such as business associations and chambers, programmes, sources of information, etc.), potential crowding out of the private sector (delivery of activities which would normally be provided by the private sector, price distortion due to free delivery of services, etc.) and inefficiency (resources not necessarily deployed in a manner maximising impact). In this context, the region may wish to examine, through an independent evaluation, the extent to which its entrepreneurship support activities are effectively communicated and absorbed by the SME sector. This would assist the region to better target its information, activities, funds, etc. For example, the regional web site is only in available in Italian; potential and actual entrepreneurs may or may or obtain information and signposting coherently and effectively.

Another challenge worth noting is the necessity to build-up the regional monitoring and evaluation systems, especially the latter. The expert team was struck by the lack of systemic evaluation of programmes to support enterprises development. For example, the Start-up programme is worth Euro 30 million and is the successor of a programme what was implemented for 11 years. 
However, there is little evidence of a detailed and independent evaluation having been carried out before formulating the Start-up programme. Consequently, legitimate concerns may be raised about the new programme and its likely impact, if it has not sought to build on what has worked and what has not in the region. Evaluation (and monitoring) should be part and parcel of all programmes involving significant public funds, especially in relation to initiatives focusing on private sector development.

\section{Opportunities}

The effects of global recession and financial crisis, the intensifying levels of competition in the last decade and the rising levels of unemployment, combined with the relatively low firm birth rate and the decreasing density of enterprises lead to the conclusion that the Lombardy region needs to rediscover the importance of developing a culture of entrepreneurship, despite the superficially impressive statistics relating GDP generation, wealth, density of enterprises, etc. Failure to do so, particularly at a time when other countries and regions are increasingly focusing on this issue, would be a strategic mistake (recommendations are presented in Chapter 2).

The preponderance of family owned enterprises, once a major source of Italian competitive strength, may be in need of reconsideration (see Potter, J., A. Proto and M. Marchese, 2010). Survey research by the Foundation Aristide Merloni suggests that: "The high average age of the sample (approximately 37 years) and the fact that the management remains largely tied to the direct involvement of the founder results in the risk of firms being anchored too closely to the factors of competitive advantage on which its initial success was based. A progressive trend of apparent inaction emerges from the observed firm behaviours, which tends to offset the positive effect of the organisational routines that entrepreneurs have been able to build over time" (author's translation). Other research suggests further weaknesses of family businesses: "First, in Italy family assets are more concentrated in family business equity, making ownership "rigid"... Second, boards of directors tend to be much less open to outsiders. ... Third, in Italy, key decision-making teams are also less open to outsiders. Qualified outside managers can have a positive impact on the succession process... Finally, Italians anticipate succession issues not much. This point may be critical for the future of the enterprise... Most of the ... private companies [in the sample] were created as the country rebuilt itself after the Second World War. With their founders now ageing, it is estimated that one third of them will have to find a successor in the next five years... However, the handover is not going smoothly." (Mussati, 2008). This succession challenge, partly connected with the low birth rate and the possibility of creating new enterprises from the old, requires renewed policy attention. The previously mentioned SBALombardiaLab focus group discussions also revealed concerns about support for the transfer of existing enterprises.

The growing levels of diversity, including the large influx of migrants to the region, are a potential source of entrepreneurship which could be more effectively utilised by the region: about $25 \%$ of the country's documented immigrant population is located in the Lombardy region. Some are relatively well-educated; others are not. However, by their very nature, such migrants tend to be relatively young, willing to take risks and naturally entrepreneurial in mind-set. Indeed, discussions with business associations in Lombardy confirm the dynamism of foreign enterprises, even during the recessionary period. The region should consider ways and means of further harnessing this economic potential through new forms of policy support which are not restricted to those who have lived in the region for the last five years. The same applies to the potential offered by women entrepreneurs, young entrepreneurs and those over 50 years of age. 


\section{Conclusion and recommendations}

The Lombardy region has been successful in generating a high density of enterprises and delivering high levels of income and quality of life for its residents. It has, in the process, also had a significant impact on the economic fortune of Italy itself. However, the effects of globalisation, intensifying levels of competition and the recession and financial crisis are impacting on the economic prospects of the region. Unemployment is increasing and the firm death date is outstripping the birth rate, resulting in a gradual decline of enterprise density. Of course, this is only a small part of a wider and complex picture, but it does suggest the need for the region to focus on the role of entrepreneurship and small firm creation.

This is not to suggest that the region is not fulfilling the requirements of the SBA. On the contrary; it has established a Mr SMEs role and initiated a SBALombardiaLab at the regional level. Overall, the region does appear to meet the general SBA obligations such as:

- P.1. Create an environment in which entrepreneurs and family businesses can thrive: the Lombardy region does well in terms of firm density, though this is declining and the firm death rate has exceeded the birth rate in recent years. The issue of family business and transmission is a serious and growing concern which must be managed effectively.

- P.4. Make public administration responsive to SMEs: a Mr SME role has been created, as has a SBALombardiaLab initiative. However, more could be done to target SME policy, such as a through a dedicated competitiveness and innovation strategy.

- P.5. Adapt public policy tools to SME needs: various policy tools which are targeted at the SME sector. However, a key weakness is the lack of effective monitoring (to some extent) and evaluation (to a large extent); without effective $M \& E$ it is not possible to adapt policy tools to SME needs.

- P.6. Facilitate SMEs' access to finance and develop appropriate legal and business environment: this is the subject of a separate Chapter, however, there are indications that the credit guarantee schemes and venture capital funds are in need of strengthening.

- $\quad$ P.7. Help SMEs to benefit more from the opportunities offered by the single market: there is a very strong regional focus on "internationalisation". However, there does not seem to be a deep understanding of what this really means or what it entails on the part of both policy makers and entrepreneurs, beyond the issue of "export".

- P.10. Encourage and support SMEs to benefit from the growth markets: policy initiatives to support strategic sectors such as aerospace, ICT, biotech, design, renewable energies, new materials, green construction, etc. are planned.

However, based on the preceding analysis, a number of recommendations could help in further developing aspects of the SBA in the Lombardy region, thus contributing to the development of a stronger institutional and policy framework for SME development. It should be noted that the recommendations connected with the issue of entrepreneurship are presented in Chapter 2 of this publication, so as to avoid overlaps. 


\section{Focus on competitiveness and innovation strategy and Monitoring and evaluation}

Currently, the region has implemented a multi-annual programme and annual plan addressing the topic of competitiveness and innovation strategy. However, a medium-term strategy is not in place. This would prove useful, as it would provide the 10 million people and 750000 firms within the region, with a clear statement and vision for development, targets to be attained, and prioritisation of policies to enable coherent programmes of support to be developed. In addition, introducing a detailed action plan with dedicated resources would be able to assist the implementation of such a strategy.

Furthermore, it is recommended that the Lombardy region establish a policy of regular and effective monitoring and evaluation for its SME programmes. This would ensure the proper use of the significant EU, national and regional funds invested into the programmes.

\section{Review and improve programmes and infrastructure}

Partly connected with the preceding recommendation in relation to monitoring and evaluation, there is a need to review and, if necessary, improve the fundamentals of enterprise support for new (and existing) existing enterprises. The region needs to address whether the programmes of support are effective and how to enhance their impact:

- Start up support: Start-up and Start.

- Business incubators.

- Science and technology parks.

- Clusters and value chains.

- Venture capital funds.

- Credit guarantee schemes.

Moreover, the following themes appear to be in need of attention:

- Spin-offs and spin-outs connected with academic institutions.

- Private business development service provision.

- Rationalisation of a multiplicity of overlapping business associations and chambers.

\section{Integrated information and services for potential / actual entrepreneurs}

Currently, the set of institutions that support entrepreneurs in the region are unclear and can result in time and cost inefficiencies. In addition to reviewing and improving the system, some specific recommendations can be suggested:

- Ensure the Lombardy website is available in English and other key languages. It is imperative for non-Italians to also gain access to information, networks and services.

- Create a single window of information for enterprises, divided into separate streams of information, support, etc. for i) potential entrepreneurs; ii) start-ups iii) access to finance and 
other key categories, thus signposting potential and actual entrepreneurs / enterprises to the main forms of information / support demanded. This could be supplemented by an Entrepreneur Hotline to reduce the time-consuming process of finding the specific information and services sought.

\section{Maximise the pool of entrepreneurial talent}

The policy of only supporting entrepreneurs that have lived in the region for a period of five years, for example, in relation to the provision of subsidies for start-ups, reduces the region's potential entrepreneurial growth. Rather than restricting access, the region should seek to harness the full palette of business talents in relation to its entrepreneurial activities. A broader range of initiatives / programmes should focus on the following target groups:

- Women: review: relatively high unemployment rate, low economic participation rate.

- Youth: high and increasing unemployment rate, a key concern for policy makers.

- Mature Population (50+): access to human capital, financial capital and know-how.

- Migrants: high propensity for entrepreneurship, in need of further support.

Such an approach would require a review of the Start-up / Start programmes, with a view to extending the activities to other key target groups and restructuring the criteria for applicants.

\section{Re-invigorate firm transmission}

Italy, including the Lombardy region, has benefitted from the success of the small, family-owned type of business. However, this particular generation of entrepreneurs is about to retire, which represents a threat, as well as an opportunity for the regional economy. This is not merely an issue of inter-generational firm succession and transmission. Many such firms face the challenge of hiring technologically skilled workers, become more innovative and demonstrate the capacity to expand into new markets and grow (see OECD, 2011). In other words, it offers an opportunity to review the current firms' strategies, products and services and creates the scope to re-invigorate and re-orientate firms for long-term sustainability and profitability. However, the founders-owners face numerous competing options, such as whether to close the firm; sell it; transfer to family member; transfer to others; attract domestic/international investors; establish joint ventures; etc.

There is a need for the region to contribute to the effective transmission from the first generation of entrepreneurs to the next one, whether to family members or others. This is normally a messy, complex and uncertain process. Whilst the problem is recognised by the region, it is recommended that it more actively invest in facilitating the process of inter-generational firm transmission through effective and well-resourced programmes focusing on awareness raising, customised training and targeted technical, legal support and financial support. 


\section{CHAPTER 4: KNOWLEDGE NETWORKS AND INNOVATION}

\section{Introduction: importance of knowledge networks and innovation}

Knowledge networks and innovation are essential features in modern competitive regional economies. This has been recognised over the years and more formal approaches have been developed to encourage more networking and the spread of innovation.

Many businesses innovate as a matter of course and also network to some extent with customers and other organisations including competitors. For SMEs much of the innovation activity is not formally recognised, often being internalised which can severely limit their growth as well as the performance of the regional economy.

Open innovation methods play a vital role in modern economic development and the generation of significant new wealth. Knowledge has always been important and has been driven from a number of sources including individuals in industry, research and academia. The key for development is to harness this knowledge and apply it to spur innovation and growth. In this way, many positive effects are created and emerge in many ways including on the performance of SMEs, numbers of new firm start-ups, proportion of high growth start-ups (often referred to as gazelles), and overall SME growth and resilience in the regional economy.

\section{Box 5. Gazelles and high growth enterprise definition}

Gazelles form a subset of the group of high-growth enterprises; they are high-growth enterprises born five years or less before the end of the three-year observation period. Gazelles are enterprises that have been employers for a period of up to five years, with average annualized growth in employees (or in turnover) greater than $20 \%$ a year over a three-year period and with ten or more employees at the beginning of the observation period. Young medium-growth enterprises, as measured by employment, are enterprises that have been employers for a period of up to five years, with average annualized growth in employees between $10 \%$ and $20 \%$ per year over a three-year period and with ten or more employees at the beginning of the observation period. The share of gazelles and the share of young medium-growth enterprises measure respectively the number of gazelles and the number of young medium-growth enterprises as a percentage of the population of enterprises with ten or more employees.

High-growth enterprises, as measured by employment (or by turnover), are enterprises with average annualised growth in employees (or in turnover) greater than $20 \%$ a year, over a three-year period, and with ten or more employees at the beginning of the observation period. Medium-growth enterprises, as measured by employment, are enterprises with average annualised growth in employees between $10 \%$ and $20 \%$ per year, over a three-year period, and with ten or more employees at the beginning of the observation period. The share of high-growth enterprises and share of medium-growth enterprises measure, respectively, the number of highgrowth enterprises and the number of medium-growth enterprises as a percentage of the population of enterprises with ten or more employees.

Source: OECD (2012), "Gazelle rate", in OECD, Entrepreneurship at a Glance 2012, OECD Publishing 
Historically networks have often formed naturally in geographic and industry patterns however this has changed dramatically in recent years as globalisation has altered the basis for competitiveness and increased the importance of creating a healthy business environment. A healthily functioning innovation system will create a constant stream of new ideas and innovations that are reflected in economic activity. This will be reflected in growth at the level of the firm and the economy. However this is not an automatic or straightforward process.

Many systems suffer from common challenges such as gaps in the network or weaknesses at key linkage points. This is often underappreciated and weaknesses can build up over time within an otherwise traditionally high performing economy. In extreme case, this can result in atrophy and a dangerous lack of behaviour change. Dynamism and agility to adapt and make economic transitions that sustain economic wealth in a region often does not happen smoothly in the market. Interventions to improve the functioning of the system (and indeed formalise a system that is suitable for effective interventions to be introduced) can lead to improvements such as more ready access to markets and technological ideas.

In many regions the components for growth of SMEs exist but the awareness of this and their configuration is often missing in companies and organisations, their wider networks and supply chains. Lombardy and northern Italy has often been seen as an area where networks and innovation is strong and offers many learning points for other regional economies in terms of industrial organisation, districts and the role of clusters. However this is a dynamic process and requires a dynamic equilibrium to exist between key players in the regional innovation system, in particular the triple helix relationships between universities and research establishments, government and industry.

The new challenges from globalisation require flexibility in relationships and attitudes towards co-operation and the value of collaborations. Good communicator channels and networks between firms and between industry and other partners (especially in the triple helix) are critical.

\section{Knowledge and innovation drivers for SMEs: some research findings}

Regions want to encourage innovation and generate the positive economic benefits in a deep and sustainable way. This makes sense at the level of the region. However at the level of the firm, there has traditionally been a dilemma for SMEs: firms seek monopoly profits from successful innovations but innovation can stimulate more competition and imitations which reduces the rewards. Research shows this may inhibit innovative and knowledge networking behaviour among SMEs.

However, the realities of global competition have changed the dynamics of competition. Competition requires SMEs to think globally from the outset and to innovate if they are to survive, preserve and develop market share. Indeed there is extensive empirical evidence to show a positive correlation between product market competition and innovative output. Competition plays a significant role in stimulating productivity and industries that experience rapid changes in technologies are likely to be those in which existing firms face greater pressure to protect their position.

Research by several authors (see Hoffman et al, 1998) shows a "u-shaped" relationship between firm size and innovation outputs, in which it is the smallest and the largest firms are the most likely to innovate. SME innovators have been characterised as being located in niche markets, largely product innovators and particularly innovators with collaborative linkages to private and public organisations such higher education institutions.

Many of the determinants of innovation within firms are internal factors such as education, experience and qualifications of the workforce alongside skills, training, cultural ethos and human 
resource tacit knowledge. This is capable of producing considerable amounts of informal innovation that can be in-built to the firm outputs and market perception. Branding and corporate identity as well as marketing can consolidate this and build further confidence, internally and externally. However other external factors must also be in place for continued growth and this includes networking activities to gather and exchange knowledge which may be utilised in the short or long term, directly or indirectly.

The role of SME links with academic institutions (and large corporations) are also important for knowledge and as an incubator for innovation, much of which can be taken forward and commercialised more readily by SMEs or spin-out enterprises rather than the larger organisation. It has also been found that high levels of education (especially in science and engineering qualifications) are positively related with levels of innovation in firms and the economy. Studies (see Cosh et al, 2005) show that in high-tech industries, knowledge related factors play a crucial role on innovation performance, while in low/medium-tech industries managerial incentives and organisational flexibilities are more significant.

Dominant firms with high market share and prominence in a particular niche, have advantages of power that can be used to innovate ahead of others and benefit most from innovations. In SMEs, process innovation is more likely and can assist increase survival and growth rates. Research (Cefis and Marsili, 2005) has shown that innovation increases survival probability by $11 \%$ and this can offset the 'liabilities of newness' often experienced by new, small firms.

Strong economies have many innovative economic actors and influencers that stimulate further investment in innovation from the traditional $R \& D$ to promotion of diffusion throughout the economy. Knowledge networks can realise close linkages between firms, research institutions and universities and act to strengthen the innovative capital of localities. In Lombardy, the agglomeration of activities in many sectors and areas across the region can be strengthened directly and indirectly through knowledge networks and interventions to promote the spread of innovation in management and other core internal factors within organisations including management style, leadership, organisational processes and marketing.

Such activity can also develop the collective characteristics associated with innovation in groups of firms or sectors to provide a range of benefits as well as becoming a source of productivity gain and competitive advantage. Clusters and network linkages can be developed to complement the regional profile in terms of firm size, structure, level and use of advanced technologies, and the use of networking as a business practice. As OECD has emphasised previously, where such attributes exist, public policy should try to build on them.

\section{Challenges of knowledge networks and innovation to Lombardy}

Lombardy is Italy's richest region and an economic powerhouse providing much of the drive for national competitiveness. The region has a reputation for wealth creation, quality and design innovation. With the leading urban and industrial strength of the Milan metropolitan agglomeration and the academic research excellence of many organisations there is much scope to develop more value for commercial economic advantage.

Innovation networks can release considerable new value and, when functioning well, they are very effective in lowering the barriers to collaboration. This can be vital to economic development and to maintaining the strength of performance in Lombardy. The region has a stock of assets, tangible and intangible including knowledge in industry, academia and research establishments that should enable continued economic growth, further high value output and jobs to be generated. 
However, in many ways, knowledge and business networks are underutilised assets in Lombardy region. Policy can play an important role and stimulate new relationships that will create new value and growth. This will improve the commercialisation of knowledge and the development of spin-out companies. Innovations can also emerge in a number of forms including the development of software (including know-how, management knowledge and systems, new process information, ideas and marketing) in businesses to complement the access to hardware based innovation systems that are technology based.

In terms of governance and culture there are many challenges facing Lombardy, as in other regions, in seeking to develop knowledge networks and innovation. However with a mix of multinational companies and string academic institutes in a regional economy dominated by small and micro businesses, there is a strong basis for growth. The region has almost 1 million companies employing over 4.3 million people.

Previous OECD studies (such as the review of the Milan metropolitan area) highlighted the importance of innovation to economic performance. This report also warned of the need for rapid action to bolster the innovation dynamics and attractiveness to support change processes in relationships within the innovation system.

Many SMEs are progressive enough to produce small spurts of innovation and achieve individual success. Global competition also increasingly requires faster, breakthrough and more comprehensive innovation. In order to create the business environment to achieve this continuously, Lombardy requires a well-structured and coherent innovation policy for the region. This can stimulate the regional innovation dynamics and generate important spillovers of national and international significance.

\section{SBA Principles: knowledge and innovation focus}

The SBA sets out guidelines aimed at promoting the small and medium sized enterprises' growth and to create a more favourable environment, in terms of legislation and bureaucracy, for SMEs. As noted in earlier chapters, it aims to reduce the bureaucratic hurdles which inhibit SME growth and development. This is especially important in Lombardy where there are more SMEs per capita than in other regions in Italy and many other countries.

There are ten principles of the SBA and, while all are relevant, three are of direct relevance to this chapter:

- P.1 Create an environment in which entrepreneurs and family businesses can thrive.

This has been a difficulty in Lombardy where many SMEs are family owned and led by a single figurehead rather than a management team with a clear growth strategy that can survive a succession or sale. It is important to introduce fresh thinking to stimulate entrepreneurs and family businesses to look more strategically at the long term prospects.

\section{- P.9 Enable SMEs to turn environmental changes into opportunities}

SMEs often perceive new standards as a burden rather than a route to develop new value and competitive advantage. Specific communications and assistance to highlight ways to identify opportunities and meet short term costs are necessary.

- P.10 Encourage and support SMEs to benefit from the growth markets 
Many SMEs have enjoyed stable levels of business and even those that export tend to focus on traditional markets in the EU. These markets now offer little growth and SMEs should be encouraged to explore the international opportunities in high growth markets including the BRICS.

Lombardy has responded to these principles and implemented several initiatives, including promotion of collaboration to access funding programmes such as ERGON and related promotion of internationalisation and innovation among SMEs. Partner agencies in Lombardy have combined resources with expenditures of over $73 \mathrm{~m}$ Euros devoted to priorities, led by innovation internationalisation, in the three axes of intervention (competitiveness of enterprises; attractiveness and competitiveness of enterprises; micro enterprise and handicrafts). SBALombardiaLAB, Euroimpresa and others have been facilitating the innovative development of the local productive systems and structures, strengthening collaborations in key sectors including energy and textiles.

\section{Overview of the innovation system performance in Lombardy Region}

The level of research and innovation in Lombardy has been consistently high. Previous work (AIRI, 2008) revealed that Lombardy has 267 research structures inside private companies and 182 companies which are leaders in innovation (European Commission, 2008). This strength is of international significance.

Other measurements also confirm the strength of research activities. In 2005, more than 1400 patents with Lombardy inventors were filed at the European Patent Office, which is approximately a quarter of the Italian patent capacity (IReR, 2010). This shows that Lombardy universities stand out in Italy in terms of their ability to patent and exploit their research results (three times higher than the rest of Italy); also the number of licences and/or active options in portfolio in Lombardy is four times the rest of Italy as are the economic returns from licensing activities.

However the predominance of SMEs in Lombardy is accompanied by lower levels of patent pursuit and registration. SMEs tend to see such activity as costly in terms of key scarce resources (including time and money) and are less willing to patent inventions or process change models. This is not unique to Lombardy where the position is relatively good in terms of recent evidence, for example, that Universities have been attempting to spread an entrepreneurial culture in the teaching staff and encourage spin outs.

This is important however much more will be required to alter the institutional perspectives which often hinder collaboration by providing little incentive in terms of rewards from such collaboration of it is developed through the university system. Universities have traditionally been beacons of academic learning and pure knowledge rather than centres for commercialisation of knowledge and innovation culture. The focus remains oriented towards academic activities ahead of industrial activities where there has been little interest traditionally - they are often seen as "worlds apart"

From a SME perspective, many companies do not engage extensively with universities. This can be due to a range of possible reasons or simply lack of knowledge, preconceived ideas and misconceptions rather than prior experience of actually engaging with a university or research institute. Many SMEs prefer other routes to network and gain access to knowledge, ides and innovations. This can include use of consultants, Chambers of Commerce and specific industry associations.

These other sources of knowledge and networking are making more links with the universities which is bringing improvements to the system however there is a need for more joint initiatives that 
are directly relevant, credible and attractive to all parties. This includes pro-active initiatives facilitated by second and third level organisations to strengthen appreciation of the value from collaborations. Other regions in the EU have expended considerable effort in this using EU funding to broker strategic connections, SME events and promotion of knowledge/networks/facilities within universities and research centres that develop culture change as well as provide access to financial, project and premises assistance.

\section{OECD survey evidence and analysis}

The recent OECD survey revealed some interesting findings on knowledge networking and innovation.

\section{Regional agencies and business organisation responses}

The survey included responses from the regional agencies (2) and business organisations (15) which influences Knowledge Networks and Innovation. Responses from these groups revealed that:

3. Networking through Public Private Consultations

- Almost half of respondents see public private consultations (PPCs) as sporadic rather than regular and a further $13 \%$ stated as don't know. There is low awareness of the value of PPCs and the aims and objectives of the consultations.

- There is a wide range of views on the influence of PPCs with $20 \%$ saying they are unstructured debates and a further $20 \%$ don't know. This indicates a low level of confidence in the effectiveness of such networking and engagement.

4. Range of Services Available

- All $100 \%$ agree that there is a very limited range of basic business services, available mainly through donor funded programmes. The narrow focus limits the degree of influence and the ability to really change behaviour long term and encourage greater engagement and collaboration.

- Confusion around if there are tailored start-up services for university graduates, young researchers and employees in the territory. This is important as the encouragement of start-ups and spin-outs from university sector is vital to spread and commercialise knowledge, ideas and innovation.

5. Availability of Specialist Premises

- $40 \%$ said there are no premises for start-up companies with special needs (i.e., laboratory space, power supply, etc.) or did not know. Provision of specialist premises can be vital for start-ups and spin-outs as well as SMEs in a cluster or industrial district with particular needs such as biotech, environmental sciences or more traditional craft infrastructure requirements. Creating such specialist space and shared facilities for testing ideas, prototyping and delivering collaborative projects has been a vital component of success in other regions such as Cambridge in the United Kingdom. It can also encourage faster growth and commitment of high growth SMEs to stay in the region as well as attract new inward investment including key elements in a specific industry cluster. 
- Lack of awareness of special needs premises requirements and availability. This should be a fundamental element of intelligence gathered by agencies and business organisation to enable them to deliver more effectively to promote development in the region.

\section{Innovation Support Services}

- $80 \%$ said that there are innovation support services, but firms in the territory have difficulties in accessing it. This indicates that barriers remains and further refinement and focus of the offerings should fit the needs of SMEs and respond to the factors perceived to inhibit their involvement in knowledge networking and innovation.

- Almost half stated that there is no data base of non-technological innovation service providers available to enterprises, either by public or private sources and little to no information on the selection criteria for firms to participate in innovation support programmes and a further $26 \%$ did not know. This reveals a muddled understanding and need to clarify what is available and how potential participants can prepare a case to access support programmes.

- Increasing use of research facilities by local private business. Further detailed examples of this would be helpful in marketing and promotion to encourage others to partner in this way.

- There is a financial support scheme for innovative enterprises, but firms in the territory have difficulties in accessing it (68\%). This reinforces the earlier point about smoothing the access process, preparing a route map for firms and clarifying the criteria for selection.

- Despite the previous finding, the survey indicates that difficulties in accessing R\&D funding are being addressed. A next step would involve gathering more information on detailed examples of which difficulties are being addressed, how this is being done and how the effects are being monitored and evaluated. This would generate valuable learning to be shared with partners and applied in other initiative improvements in the region.

- Survey responses reveal a perceived lack of adequate advice on intellectual property (IP) issues. This is a fundamental concern for SMEs looking to innovate and internationalise.

\section{Internationalisation Services}

- All provide advisory and support services for internationalisation for SMEs in the territory. This is a topic that is recognised as vital in opening up new markets, new sources of ideas, collaboration and business. A number of organisations including second tier business groups are encouraging more SMEs to explore the international market opportunities. This opens up further engagement on a wider agenda covering issues of competitiveness, innovation and awareness of the strengths and challenges facing businesses and the innovation system in Lombardy.

- There are no SME internationalisation through coaching by large companies initiatives, which are available for SMEs. The ability to tap into larger company resources, networks and experience could be a valuable addition to attract more SME interest and engagement. 


\section{Universities and research institute responses}

Seven universities and seventeen research institutes responded to the survey and revealed that:

- $58 \%$ of universities (65\% of institutes) do not know if technical university faculties and research organisations in the territory have access to accredited testing and calibration laboratories.

- All collaborate in research activities with firms and 86\% (53\% institutes) say this is showing increasing signs of success including cluster developments; in 2011 the University of Bergamo signed around 100 contracts for research with local companies.

- All university respondents (88\% in institutes) are aware of innovation support services (e.g. support to innovative start-up, human capital mobility schemes, innovation vouchers, clusters and networks, etc.) and $85 \%$ have benefited from them (53\% in institutes).

These responses provide encouragement that the "academic" sector is engaging more with SMEs and open to further joint initiatives for mutual benefit. This will contribute to deeper culture change and improved performance in the regional economy.

\section{Challenges and opportunities}

In reviewing the evidence and information gathered from discussions in Lombardy, we have summarised the strengths, weaknesses, opportunities and threats as a precursor for drawing some conclusions and making recommendations on future actions. This will assist to improve the implementation of SBA principles for the benefit of SMEs as well as bolstering the knowledge and innovation networks in the region.

\section{Strengths}

As noted earlier, Lombardy is fundamentally a strong economy. There are many assets and factors of production that exist and are capable of further development to improve economic output and competitiveness of SMEs with regard to knowledge networks and innovation. Significant strengths include:

- Diversity of economic actors and high value of economic output as shown by GDP and other measurements.

- High knowledge content employment in a range of sectors.

- Fluid movement within executive positions to spread ideas and knowledge with large inflows of commuter workers in the region.

- Knowledge and expertise in specific higher education and research institutes, many of which are of global significance and actively promoting international linkages.

- Existence of clusters in various industries, including traditional ones such as furniture and more recent concentrations such as bio-technology.

- Industrial districts and agglomerations renowned for quality design, networking and innovative products. 
- Diversity of SMEs and sectors including growth of design and creative industries to develop new value and extend value connections from production and services.

- Strong local supply chains which provide thickness to capture and retain more value in the region and dynamic relationships between different players where knowledge and networks are fundamental to wealth creation.

- Global research and design capabilities with much of the Made in Italy brand value being generated in the region and covering a wide range of industry sectors, products and services.

- Technical product research and design which has been the cornerstone of many industries including furniture, fashion, automotive industries and cross industry innovations in textiles, engineering and services.

\section{Weaknesses}

The challenges in Lombardy reflect the difficulties in many regions. These challenges require constant attention and consideration within policy development and new initiatives that can address weaknesses in the knowledge networking and innovation system. Significant weaknesses and challenges include:

- Limited cross fertilisation of ideas between education and industry - in a region with so many basic strengths there would be an expectation of more connections to generate future wealth opportunities and greater international market involvement. While individual institutions (such as Milano-Bicocca University and individual chambers and associations) do have many good links these are not as numerous as in other globally significant regions and do not always appear to be maximised to the benefit develop the local innovation system and multiply knowledge networking.

- Low levels of collaboration and success stories. Statistics on the number of patents registered, international collaborations and SME involvement in major projects are modest and there is a lack of promotion of case studies to share learning and spark new networking and innovation.

- There is general confusion on assistance from different institutions and the regulations that determine assistance. From the OECD survey responses, this would appear to be the case within all organisations not just SMEs.

- There is a general lack of appreciation of an innovation system and how this could be developed for mutual benefit. This could reflect confidence in existing networks and complacency around the amount of effort required to generate innovations. This cultural factor will take time to change and require more involvement from external influences.

- The importance of marketing and soft skills to identify and exploit new opportunities for growth is undervalued. Local networks and quality of product continue to be the foundations of many SMEs and other actors in the local economy. Internationalisation is promoted yet more could be created through more focused application of knowledge and partnerships through collaboration.

- Lack of commercially oriented knowledge search and foresight activity. SBALombardiaLAB is an excellent initiative and encourages cultural change through 
specific areas of action however more future oriented research and foresight could yield quick wins for many partners and develop the innovation system.

- Disconnect between research and development for economic advantage. There are many areas and industries where knowledge exists and partners could work more closely to take this forward and target international market opportunities.

\section{Opportunities}

Lombardy has many opportunities to develop based around fundamentals of the regional economy, networks and innovations. The region is geographically well situated, accessible to markets and neighbouring regions with high growth centres and high levels of innovation in SMEs. Particular opportunities for Lombardy include:

- Developing additional economic effects and spill-overs to SMEs from a number of significant knowledge intensive clusters and specific technologies including bio-tech, agriculture, green energy, design and creative sectors.

- Encourage more networking and knowledge sharing from the diversity of strengths in institutions and potential for spin-outs.

- Develop the opportunities in the services sector around key clusters and industries.

- Develop the agglomeration effects from industrial concentrations and the metropolitan magnet effects of Milan as a global city.

- Further development of supply chains and spill-overs to SMEs. This could target specific links in global chains and become pro-active policy.

- Directing more resources towards support for the creation of high growth, high value new businesses (gazelles).

- Creating infrastructure to develop facilities for supply chains, retain and attract new talent. The OECD survey responses confirmed the opportunities to do more in this area.

- Develop the range of knowledge sharing and transformational change initiatives that promote an innovation culture in SMEs.

- Develop more demonstration collaborations between industry and academia and showcase successful examples to inspire more knowledge sharing, innovation and embed the ideas around collaboration in the culture of management.

- Emphasise the importance of developing awareness of innovation from schools onwards and continuously reinforce the messages through community engagement, industry collaborations and media promotions.

- Involve large companies directly in initiatives to spread practices and strengthen linkages that can create new supply chain opportunities in international markets and different sectors that require SMEs and institutions to flex and innovate practices. 
- Test more new ideas and pilot initiatives/engagements that promote knowledge sharing and innovation throughout the regional economy and society.

\section{Threats}

All regions face constant threats from within and from external shocks. Preparedness for handling such threats is vital to avoid negative consequences. A number of threats are apparent in Lombardy:

- Competition. This drives innovation and can be a real strength but competition from other regions and countries can take various forms, from low cost basis to high knowledge content basis that changes previous competitive advantages. Foresight and continuous research alongside knowledge sharing is essential to maintain vigilance on such threats.

- Culture and loss of talent. Global economics is a reality and ease of access to knowledge and opportunities, communications and networking can lead to businesses and key people relocating. Italy is renowned for culture however specific innovative industries cluster in regions where the combination of environmental conditions is most attractive. The quality of knowledge sharing and innovation is a factor in this and weaknesses in Lombardy system could lead to an outflow of knowledge, IP and human resources.

- Comfort and tradition can lead to complacency about the ability to generate wealth and attract activity. One consequence of this can be falling standards.

- Lack of commitment to collaborate limits knowledge networking and can stifle innovation;

- Governance and reward structures in universities and research institutes can act as a disincentive to commercialisation and spin-outs;

- Target chasing by agencies, institutions and SMEs. This can distort behaviour and can be exacerbated by funding programmes as partners and projects are re-packaged to access assistance;

- Availability of funding.

In reviewing the SWOT analysis, a number of immediate and long term actions can be suggested.

\section{Conclusions and recommendations}

Research by the OECD has consistently emphasised the need for regions to move up the value chain in order to compete and prosper in the global marketplace. In order to do this, SMEs must have ready access to external sources of information, knowledge and assistance to build their own capacity and ability to reach growth markets. Collaborative innovation works best: greater inter firm collaboration and exchange within networks including universities, research institutes and agencies is essential.

In looking at the three SBA Principles of direct relevance to this chapter some conclusions and recommendations follow:

- P1: Create an environment in which entrepreneurs and family businesses can thrive. The structure and cultural emphasis on micro and family businesses in the region means that many challenges are deep rooted in Lombardy. Changing culture and structure takes time if 
it is to be done properly and it will be important to introduce fresh thinking to stimulate entrepreneurs and family businesses to look more strategically at the long term prospects.

- P9: Enable SMEs to turn environmental changes into opportunities. The need for achieving standards and accessing new business opportunities remains underappreciated with a short term perspective that such requirements represent an additional cost burden rather than a basis for developing new business. There is a need to change this perception by facilitating SME engagement and going beyond the provision of information to broker real projects that can become demonstrators for SMEs. In this way, interventions can be more productive and stimulate long term change from within SMEs.

- P10: Encourage and support SMEs to benefit from the growth markets. The BRICS countries are the source of future growth in GDP and export markets yet few SMEs explore or export to these territories. The dependence on low growth traditional markets will limit growth and it is essential that networking initiatives promote more internationalisation as part of holistic policy strategies on competitiveness, innovation and growth.

Lombardy has number of fundamental strengths and a range of initiatives underway through partners and the SBALombardiaLAB in particular. These initiatives recognise that globalisation and the increased intensity of competitive change pressures have made innovation and more dynamic levels of inter-firm co-operation essential. However much more could be done to develop knowledge networks and encourage more innovation by SMEs and partners.

\section{Organisational alignment to simplify assistance packages}

There is an important role for regional agencies and partners in stimulating innovation and synergies in strategic areas and partnerships. However this can become a crowded space. In Lombardy, there are good examples of collaborative initiatives but not enough with evidence of impact or how the efficiency of the selection process works to generate the highest impact from interventions.

For SMEs, evaluation evidence would demonstrate the value of participation which involves considerable investment in more than monetary forms as well as raise the credibility of assistance agencies. There is a plethora of organisations in the private sector but the needs of local SMEs are often difficult to match other than by immediate short term assistance such as access to funding and introductory change products in the two recognised priorities, internationalisation and innovation.

Much more could be done to clarify the interventions and how they perform to stimulating more sophisticated demand from SMEs as well as enticing more meaningful commercially based engagement by and with research and higher education institutes. These are all fundamental areas for achieving sustainable success and growth.

\section{Improving the innovation system and collaboration}

Improved co-ordination of the knowledge infrastructure and the range of actors and institutions providing services in Lombardy is essential if the region is to make the most of these assets. This will have a direct effect on the competitiveness of SMEs notably in improved levels of innovation capacity and international trading awareness. Improved structures to promote knowledge networking and innovation will provide the context for more competitive SMEs in the region and generate more spillovers to national competitiveness. 
Agencies require to clarify the assistance that is available and the criteria to determine the levels of support. A more sophisticated and nuanced approach would give priority to allocating resources to meet real opportunities and demonstration initiatives that could support wider behaviour change amongst SMEs and partners. The three key groups of actors (firms, academia and government) all have important roles to play in driving the regional economy forward to achieve sustained high growth. This will require recognition of how each cane perform and contribute in ways to lever greater productive collaboration. For example, there is a need for more concerted efforts to bridge traditionally different perspectives of academia (curiosity driven research) and business (commercial market driven investment).

More and more innovation comes from collaboration in one form or another. Conversations with partners, customers and competitors should be encouraged as they are all part of the knowledge mix that can inspire critical innovations for business and economic growth. SMEs, all companies, universities and research institutes all benefit from sharing knowledge and other resources to open new opportunities as well as other benefits including lower costs and avoiding costly mistakes.

This can also address the challenge of the bulk of lagging SMEs in less glamorous sectors of local economies. These micro and small businesses should receive offerings to encourage development and improved competitiveness. The second order intermediary and representative organisations will have an important role in engaging with the mass market of SMEs across all sectors.

\section{Targeting high growth enterprises as exemplars and catalysts}

Economies dominated by SMEs gain more from an open innovation approach where the emphasis is on practical market opportunities with clear commercialisation routes. This has become more critical with the economic crisis and will be essential in developing high value competitive propositions post crisis. Also as resource pressures increase, the support for firms with greatest growth potential attains more importance as they can yield disproportionate returns in many ways not simply financial. This would encourage companies that are positioned and most able to adapt new knowledge and new technologies in a productive way.

The targeting of high growth start-ups is an area where careful targeting could generate new wealth and commercialise ideas more quickly. This will require a broader range of support including premises, IP advice, market research and team mentoring on collaboration rather than simply financial support.

\section{Encouraging service innovation initiatives}

The growth in the economic share and value add from services makes this an area for further specific action. Many of the leading economies and agencies have recognised this. In Lombardy there remains a relatively lower emphasis overall on the contribution of services and the importance in terms of innovation and business success.

There is an example from Finland, the "Serve" scheme, which supports non technical innovation could merit further review. The Serve scheme aims to encourage the development of innovative service concepts and service business models in companies; strengthen and diversify service related innovation activities, especially in SMEs; improve productivity and quality of service activities in various industries; and boost academic research in the area of service development. A range of instruments are applied to deliver this initiative including financial incentives, soft skills development and HR support. In most cases, public funding support for innovation in Finland requires evidence of productive collaboration. 


\section{Learning from the Nordic Experience}

The Nordic countries offer a number of lessons and are renowned for their progressive policies on innovation networks including creating the general framework conditions for innovation to flourish (taxation, physical infrastructure, legal and regulatory). Agency initiatives in countries such as Finland (TEKES) and Sweden (Vinnova) emphasise the importance of interventions that develop other innovative factors including incremental improvements of products, processes and services, organisational change, company learning processes, and the use of design, branding and marketing.

Research supported by the Nordic Industrial Fund back in 2003 examined good practices in Nordic innovation programmes which proposed that authorities take a close look at their innovation policies, and see if the following functions are covered:

- Measures aimed at improving the absorptive capacities of firms, i.e. their ability to learn;

- Measures aimed at broadening the activity base of the firms, i.e. their ability to invest in risky - but potentially rewarding projects;

- Measures targeting unborn industries or technologies - policy makers should develop policy instruments that guide radical entrepreneurs to sources of finance, advice and relevant competences;

- Measures aimed at improving the interaction between knowledge institutions and industry.

These considerations are relevant in Lombardy today.

Other areas where specific actions could generate knowledge networking and innovation benefits include:

- Organising more intra-sector events to discuss knowledge, innovation and commercialisation routes linked to assistance and partner collaboration.

- Gathering data and future foresight to highlight specific cluster and sector opportunities in Lombardy. Events and communications throughout the network partnership organisations would then be used to maintain awareness and stimulate responses from SMEs and partners.

- Integrated monitoring and evaluation, benchmarking and evidence gathering to track the change effects from new networking and innovation initiatives to highlight success and share learning.

- Stimulating debate and arranging specific opportunity events to share data and evidence in a solution focused way to prompt SME and partner response to encourage more sophisticated demands and applications for different forms of assistance.

- Create a series of network innovation forums for discussing future developments in Lombardy and practical business competitiveness lessons from international markets, potential for international collaborations and best practices from other EU and OECD regions.

- Celebrate successes through awards and competitions that recognise and reward both incremental innovation and radical game changers. 
- Involve more large enterprises and multinational companies to oxygenate the pool of innovation and bring new thinking to SMEs, universities and research centres and partner organisations.

- Stratify assistance in line with customer capabilities and potential for growth - key sectors with intense creativity and links in supply chains will be given priority however all SMEs must be offered services to spread the innovation message, expand the community of knowledge driven innovative companies and prepare them for future growth.

In the end it is an innovative culture that will determine economic success. SMEs, universities and other partners must be encouraged to exploit their potential more fully, extend their reach through collaborations and use knowledge networks to access new sources of innovation that will in turn create new growth. 


\section{CHAPTER 5: ACCESS TO FINANCE}

\section{Introduction}

Access to finance represents one of the most significant challenges for entrepreneurs and for the creation, survival and growth of small businesses. Accordingly, ensuring that SMEs and entrepreneurs have access to adequate sources of financing has turned into a major policy objective across many regions, at different levels of development and with different business financial structures. The financing challenge has been exacerbated by the 2008-09 global financial and economic crisis, and the following slow and uncertain recovery. The credit crunch hit SMEs more severely than large companies. In fact, SMEs and entrepreneurs have suffered a double shock: a drastic drop in the demand for goods and services, hence in their revenues, and a decline or slowdown in SME lending. The amount of funding has been only part of the problem. Credit conditions worsened for SMEs, in terms of shortened maturities, increased requests for collaterals and guarantees. These events have significantly affected SME cash flows forcing many into bankruptcy and resulting in record levels of unemployment in many countries and regions. National and local governments have responded with a number of different measures to support sales, prevent the depletion of SMEs' working capital and enhance their access to credit (OECD, 2012a). However, the continued increase in bankruptcy rates suggests that the crisis is not over yet for SMEs. Even in countries and regions in which bankruptcy decreased from its 2009-2010 peak, the situation is not back to the pre-crisis level.

Over recent years, quantitative easing by central banks has been the key instrument to shore up troubled banks, stabilise economies and speed recovery. The aim is for banks to use this money to lend, increase investment, and boost the economy. However, the impact of quantitative easing on lending to business - and to SMEs in particular - is up for debate: there is a lack of definitive evidence but a large share of firms continue to lack funds they need to invest, grow and create jobs.

The crisis has particularly exacerbated the financing problems of new and high-growth firms. Funding through business angels and venture capital contracted sharply across all OECD countries. The 2012 OECD Scoreboard on Financing SMEs and Entrepreneurs (OECD, 2012a) shows that, between 2007-2009, total venture capital invested dropped almost $80 \%$ in the Netherlands and $60 \%$ in Finland. Between 2008-2009, it dropped by $48 \%$ in Sweden and 42\% in Switzerland, to name a few cases in Europe.

The recent crisis may have temporarily diverted attention from the long-standing problem of financing new and high-growth firms, but it is re-emerging as a prominent issue in the post-crisis period, since these companies are often at the forefront in job creation, in the application of new technologies and in the development of new business models.

The SBA acknowledges the key role of SMEs' and entrepreneurs' access to finance for growth and job creation. It also encourages improvements in the area of venture capital and targeted measures to increase the awareness of existing and potential investors about the opportunities offered by SMEs and new firms. 
The present chapter discusses the SME financing gap and the rationale for policies in this area. It comments on SBA principles and recent assessments on access to finance for SMEs and Entrepreneurs in Italy, including evidence about SME financing trends during the crisis and policy responses to alleviate liquidity constraints. The country-level indicators set the framework for discussing the main characteristics and key evolution of the business financing sector in Lombardy. The chapter focuses in particular on credit guarantee schemes, which importantly characterise the region's financial setting and are currently undergoing profound restructuring. In this light, the chapter reviews the result of the OECD survey and comments on challenges and opportunities, placing finally the emphasis on areas for improvement and international best practices.

\section{The SME financing gap}

The "SME financing gap" is the object of a long-standing debate, which has been revived by the recent financial crisis. The gap describes the situation where a sizeable share of economically significant SMEs cannot obtain financing from banks, capital markets or other suppliers of finance. In other words, some SMEs and entrepreneurs that have the capability to use funds productively if they were available do not have access to those funds (OECD, 2006).

At the theoretical level, there is some controversy as to whether government policies should be designed to plug alleged business funding gaps. The debate has focused on the excess of demand vs. the credit rationing hypotheses. According to the first (e.g. de Meza and Webb, 1987), there exists such a gap if interest rates are below the equilibrium, market-clearing rate, as a result of intervention by authorities, which leads to excess demand for loanable funds. The seminal work by Stiglitz and Weiss (1981), on the other hand, underlines the existence of failures in financial markets, due to asymmetric information and agency problems. In particular, banks have difficulties distinguishing good risks from bad risks and in monitoring borrowers once funds have been advanced. They will hesitate to use interest rate changes to compensate for risk, in the belief that, by driving out lower-risk borrowers, high interest rates may lead to a riskier loan portfolio, thus setting in motion a process of adverse credit selection. Therefore, they have an incentive to engage in credit rationing (OECD, 2006).

Although the credit rationing argument would apply to businesses in general, SMEs are especially affected because the problem of information asymmetry is more acute in their case. In fact, most of them are unlisted and are not required to disclose information. The broad range of SMEs' productivity and survival rates also contributes to the credit rationing by financial institutions. The asymmetric information often leads to situations in which lending is not based on expected return but rather upon access to collateral (i.e. an asset of borrowers, the possessive right of which is provided to lenders in case of default). The problem of increased request for collateral has been especially acute during (and in the aftermath of) the crisis across many OECD countries and regions (OECD, 2012a). Furthermore, the increased relevance of collaterals for accessing credit matched with high volatility in real estate markets, usually the main source of collaterals for SMEs. 


\section{Box 6. Conflicts in the credit process}

Conflicts may arise in the credit process, which typically affect small businesses and young or new entrepreneurs to a larger degree than large firms. This is mainly due to undercollateralisation of small and young businesses and lack of financial literacy. The following categories illustrate common source of conflict:

i) Problems of communication may arise when the entrepreneur is unclear in the request for credit. The bank may make continual requests for additional documentation or for consecutive meetings without adequately explaining the purposes of these requests. The entrepreneur may have difficulties in explaining a working capital shortage, for example when problems arise in collecting funds from customers.

ii) The bank may request that the entrepreneur seek official credit guarantor or a mutual guarantee society as a pre-condition for receiving credit. The entrepreneur may not be aware of the possibilities and sources to obtain support from guarantee schemes.

iii) In some cases, the entrepreneur may have a viable proposal that is not presented with sufficient clarity.

iv) In some other cases, substantial changes may be required in the entrepreneur's business plan. For example, the plan may propose to spend an excessive share of resources on the development of a new product and insufficient resources on production of the product.

v) Insufficient authority on the part of the local bank may limit the scope for financing of the enterprise. This may have adequate local support for the project due to contacts in the local business community, but the decision may be made at a higher echelon in the bank.

vi) Conflicts over existing credits may exist. In some cases the entrepreneur may have a line of credit and is experiencing difficulties in meeting obligations. The entrepreneur may request an increase in available consolidation of existing credits or a restructuring. Conversely, the bank may tighten conditions on credit.

Source : OECD (2010), Assessment of Government Support Programmes for SMEs' and Entrepreneurs' Access to Finance in the Global Crisis, OECD, Paris

\section{SBA Principles: easing access to finance and developing a supportive framework}

Among the principles that should guide the design and implementation of SME and entrepreneurship policies, the SBA places a specific focus on easing access to finance, enunciating that efforts should be devoted to:

P. 6: Facilitate SMEs' access to finance and develop a legal and business environment supportive to timely payments in commercial transactions.

The 2011 SBA profile for Italy ${ }^{6}$, produced by the European Commission, describes access to finance as an area of concern, in which the country performs below the EU average. Even more importantly, a downward trend across indicators was observed over 2005-2011 (EC, 2011). As illustrated in Figure 3, the indicators for which the greatest (negative) distance from the EU average is recorded are: strength of legal rights ${ }^{7}$; interest rate spreads between small and large loans; share of EU Structural Funds dedicated to stimulating entrepreneurship and SMEs; venture capital investments

6 Ministero dello Sviluppo Economico (2012) Small Business Act. Support initiatives for micro, small and medium enterprises in Italy. Report 2011.

7 the strength of legal rights index measures the degree to which collateral and bankruptcy laws protect the rights of borrowers and lenders and thus facilitate lending. 
and; share of European Agricultural Fund for Rural Development (EAFRD) allocated to support business creation and development. In other terms, the main gaps or weaknesses are identified in the legal and supportive framework, including the orientation given by national authorities to investments of EU funds. On the other hand, Italy performs above the EU average when considering credit information and approval of SME loans by the bank sector.

Figure 4. Access to finance: indicators for Italy

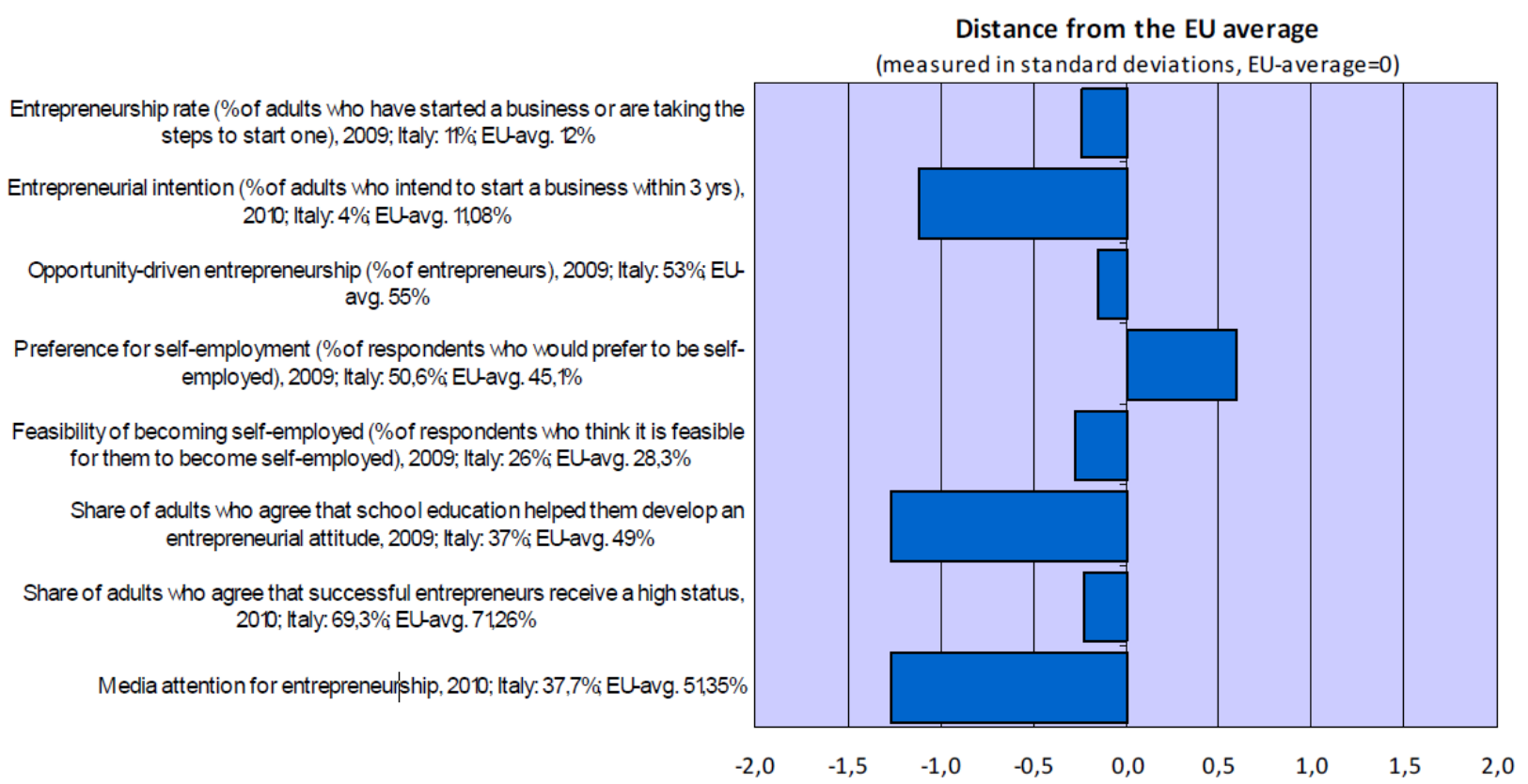

Note: Data bars pointing right show stronger than EU-average performance and data bars pointing left show weaker performance.

Source: European Commission (2011), SBA Fact Sheet 2010/11 (http://ec.europa.eu/enterprise/policies/sme/facts-figuresanalysis/performance-review/files/countries-sheets/2010-2011/italy_en.pdf)

The evaluation about the relative resilience of SME lending in Italy through the crisis, though with increased costs of access, is consistent with the evidence from the 2012 OECD Scoreboard on SME and Entrepreneurship Finance. Figure 4 shows that SME loans grew steadily until mid-2008 and then decelerated sharply during the crisis, but never reduced in absolute terms, contrarily to other EU countries (e.g. Denmark, Netherlands), which experienced negative trends in the nominal amounts of SME loans in 2008-09. The less severe impact of the crisis on Italy's banking system can be explained by its sound model of intermediation, more oriented towards direct lending than transactions on capital markets. Even the largest banking groups, more reliant on wholesale funding and therefore more exposed to transmission mechanisms, had a lower level of leverage compared to their foreign counterparts (OECD, 2012a).

At the same time, the over-reliance of Italian SMEs on debt financing implies that the changing conditions in the banking sector affected heavily the performance and survival of SMEs. Italian SMEs tend to rely very little on risk capital and also reinvest profits in their business activity only to a limited degree. The dependence on debt, and the reliance especially on short term funding, result in a significant vulnerability during downturns in the economic cycle and periods of credit tightening. 
Figure 5. Lending to firms in Italy (2005-2011)

Monthly data, 12 month percentage changes

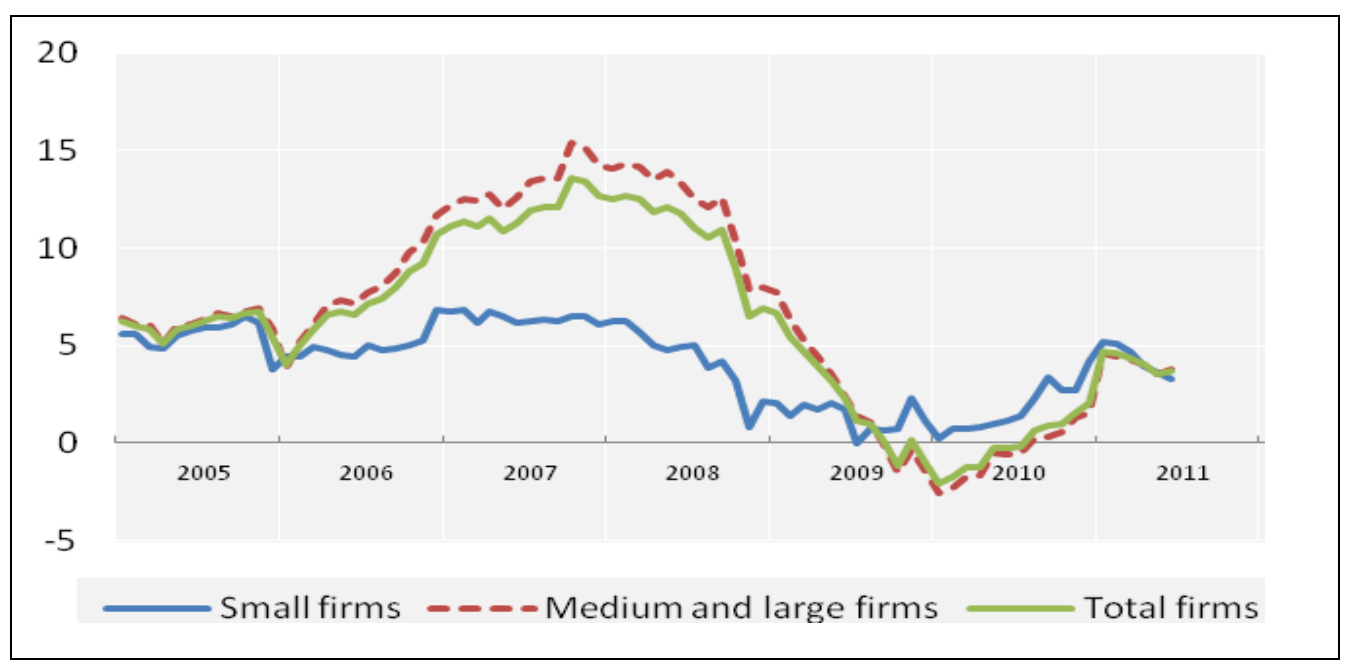

Source: OECD (2012), Financing SMEs and Entrepreneurs. An OECD Scoreboard, OECD Publishing, Paris.

Since 2008, Italian firms have been facing more stringent conditions for accessing bank credit (in terms of margins, maturities and specific covenants aimed at limiting risk), which mirrored the perception of heightened risk, common across the euro area. Furthermore, risk capital shrunk. Venture and growth capital fell dramatically between 2008 and 2009, recovering slightly in 2010, but not for SMEs. The main segment benefiting from increase in risk capital was in fact that of firms with $1000-$ 4999 employees (OECD, 2012a).

Delayed payments have represented an important source of cash flow deterioration for SMEs. Timely commercial payments define an enabling financial environment, according to the SBA principles. Since the outburst of the crisis, payment delays increased, due to the drop in sales and the more difficult access to credit. In this respect, smaller creditors and suppliers have suffered at the bargaining power of large firms, which could alleviate their liquidity constrains by delaying payment. However, Figure 3 indicates that Italy has been performing slightly better than on average in the EU along this dimension. In fact, payment delays reduced for SMEs in $2011^{8}$. At the same time, it is important to note that, in the country, payment delays by the public sector have increased in the aftermath of the recent crisis, adding to the cash flow problems of firms, particularly of SMEs. In 2011, firms had to wait 180 days to receive a payment from the public administration, compared to 128 days in 2009. Within this framework, the Lombardy region exhibits a better performance in terms of payment delays by the public administration. For instance, in the health sector, where the average payment delays are particularly high (299 days on average in Italy in 2011, according to Assobiomedica), the public administration in Lombardy pays suppliers on average in 112 days.

\section{Policy responses to the crisis}

Several measures have been taken by the Italian government to limit deterioration of working capital and sustain SME lending at a time of decrease in cash flow and general credit tightening. The one-year moratorium on SMEs' debts, which allowed firms with no bad debts, restructured loans or

8 Observatory on landing and payments for enterprises ( sui prestiti e i pagamenti delle imprese), Cerved Group. 
ongoing foreclosures to suspend repayments, was extended until mid 2011. To boost liquidity, the government also provided tax exemptions, tax deduction and delayed payment of VAT.

Taking into account the relevance of debt financing for SMEs and the diffusion of guarantee instruments, which are an important refinancing measure consistent with the Central Guarantee Fund (CGF), this eases SMEs' access to credit by providing guarantees and counter-guarantees. The CGF has produced its effects through the well established multi-layer system of credit guarantee schemes in the country (Figure 5). In the Italian context, an important role is played by Mutual Guarantee Societies (Confidi), which operate at the local level, typically in industrial areas that are characterised by clustering of highly specialised and interconnected SMEs and a well defined territorial economic identity, related to a sector or value chain. As such, these schemes have strong linkages with the territory and the advantage of mutual knowledge and trust among shareholders. Moreover, as the Confidi) suffers a loss in case of default, members have strong incentives to closely monitor their peers which deters borrowers from excessively risky behaviour and increases the repayment probability of the loan. For this reason, Confidi) have been considered effective in addressing the information asymmetries between the bank and the SME and occupy a good position to assess the SME creditworthiness.

Italian Confidi are among the most important mutual guarantee schemes in Europe ${ }^{9}$. Almost 1 million Italian SMEs are members of a Confidi and guarantees granted by these account for $41 \%$ of all guarantees issued by European credit guarantee schemes. This also reflects in the highest share of national GDP (1.4\%) accounted for by guarantees across Europe (De Vincentiis, 2008).

Figure 6. Mutual Guarantee Systems (MGS) in Italy (Confidi)

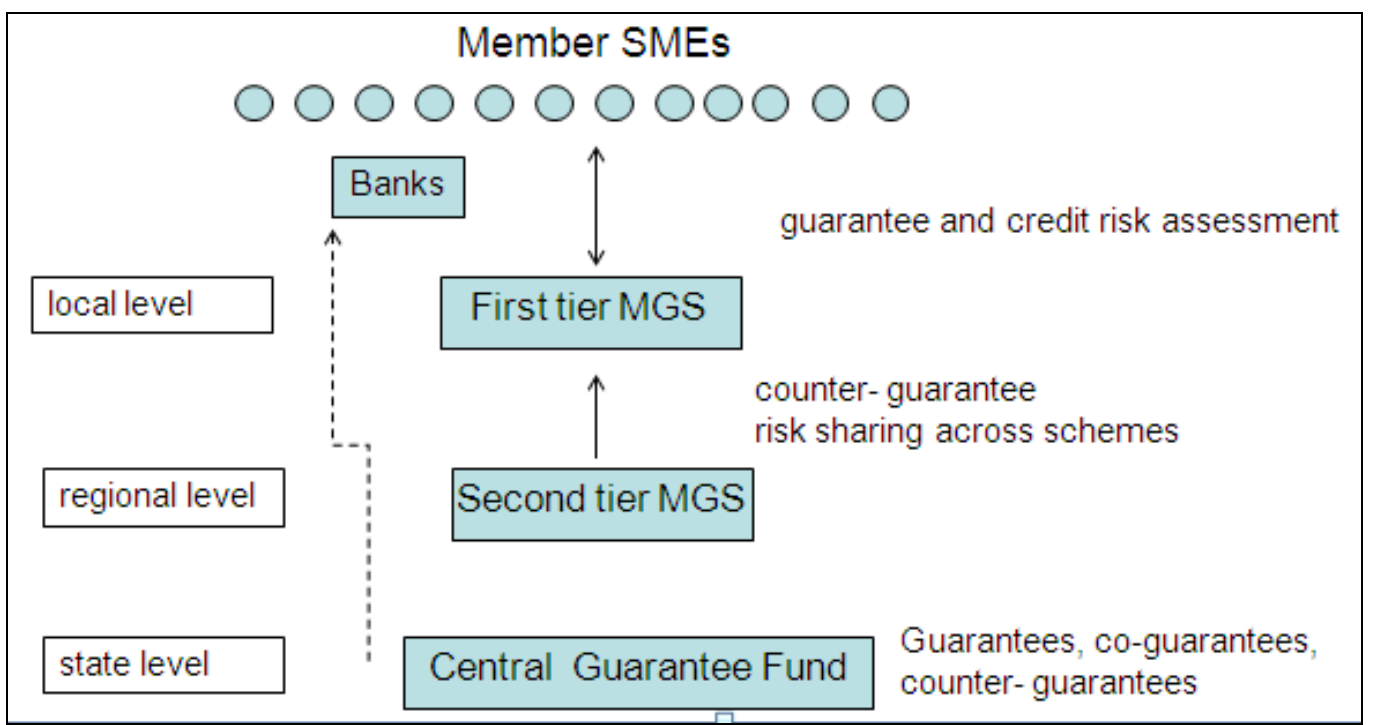

Source: OECD (2012), SME and entrepreneurship financing. The role of credit guarantee schemes and mutual guarantee societies in sustaining finance to small and medium-sized enterprises, OECD Working Party on SMEs and Entrepreneurship, Parıs

$9 \quad$ MGSs can be classified into institutions with direct and indirect mutuality. Direct mutual schemes are the result of a collective effort of small businesses in order to improve their access to credit, whereby participating entrepreneurs are at the same time shareholders of the institution. In order to be eligible for support from mutual guarantee schemes, firms generally have to be members of the institution. Moreover, membership implies that they are directly involved in the management, for example by voting the board of directors of the institution. In schemes with indirect mutuality, the institution is managed by a chamber of commerce or a trade association of which firms are members. 
In order to expand the operation of the Central Guarantee Fund, both local and regional governments have increased its capitalization by EUR 1.5 billion for the period 2009-2012. One modification included the eligibility of the previously excluded crafts enterprises for guarantees. Moreover, the maximum guarantee per firm was increased from EUR 0.5 million to EUR 1.5 million. As a consequence of the enhanced capitalization, the fund increased its operations. In 2009 only, guarantees worth EUR 2.7 billion were issued, against an amount of EUR 8.1 billion over the entire period 2000-2009. The amount of credit was EUR 4.9 billion in 2009, the corresponding figure for the period 2000-2009 is EUR 15.9 billion (AECM, 2009; Mistrulli and Vacca, 2011). In 2011, the CGF supported about 55000 firms, mainly micro and small firms, providing more than EUR 5.2 billion in guarantees for EUR 9.1 billion worth of loans. Apart from public support via the CGF, chambers of commerce across the country supported the operations of Confidi through direct funds and counterguarantees.

Another support to SME lending was given through the use of the Deposits and Loans Funds (Cassa Depositi e Prestiti). EUR 8 billion were drawn from postal deposits and made available to the banking system for SME lending. At the end of 2010, it was estimated that EUR 2.8 billion had been allocated to SMEs (OECD, 2012a).

\section{SMEs and entrepreneurship finance in Lombardy}

The regional financial system is characterised by a high density of financial intermediaries, which persists in spite of the important process of consolidation that has been taking place since the 1990s. Indeed, regional banks have been the main players in the most important M\&A operations in Italy, which led to the creation of sizeable bank groups, Intesa San Paolo and Unicredit. In 2008, 23.5\% of Italian banks had their legal seat in Lombardy. Furthermore, the region hosted $79 \%$ of affiliates of foreign banks that are active in Italy (Schena, 2010).

At the same time, the region accounts for a non marginal share $(10.8 \%)$ of Italian credit cooperative banks (Banche di Credito Cooperativo - BCCs), which grant loans to all economic categories represented among the owners. BCCs are autonomous institutions but cooperate through regional and national networks. In particular, the regional federations provide technical assistance and internal auditing to their members. BCCs have also been going through a process of consolidation, but their number in Lombardy has remained rather stable over the last decade.

The extended network of Mutual Guarantee Schemes (Confidi) plays a key role in the Lombardy's system of SME financing. The 2011 survey by Unioncamere Lombardia on 31 regional Confidi counts 238000 firms that are associated to these schemes. Historically, the Confidi system has been highly fragmented, with a large number of small schemes serving specific groups of enterprises and territories. However, over the last 5 years, the process of consolidation that has characterised the entire financial system has also affected the Confidi structure. At the regional level, a significant process of aggregation has been taking place and medium-sized players, which in some cases operate at the national level, have emerged. Nowadays, the main players control about $76 \%$ of the regional market. At the same time, other national players have entered the market, as an effect of their commercial development strategy or as a result of consolidation processes. Important changes have been also taking place at the higher regional level. Through a process of aggregation, a supervised second-tier Confidi was created, Federfidi Lombarda (Unioncamere Lombardia, 2011). This is now the sole counter-guarantee institution in the region and the main guarantor for local guarantee institutions, which in turn provide guarantees benefiting SMEs in the artisan and industry sector. In July 2012 Federfidi Lombarda signed a two-year agreement with the European Investment Fund (EIF), under the EU Competitiveness and Innovation Framework Programme. This follows another guarantee agreement over 2008-2011 and, through a EUR 280 million counter-guarantee fund, is intended to 
sustain loans to SMEs for more than EUR 600 million. Unioncamere Lombardia and the region's chambers of commerce contributed with EUR 5 million.

The changes in the Confidi structure are to a large degree a response to the changes in the regulatory framework (e.g. Basel II and Basel III), to the overall evolution of the financial market and to the more extended functions charged to them during and in the aftermath of the crisis.

On the regulatory side, Confidi can be classified into supervised schemes (cfr. art. 107 of Testo Unico Bancario, the national law of reference), which are under the direct supervision of the Bank of Italy, and the smaller unsupervised schemes (cfr. art. 106 of TUB), which are under inspection of an external body, also subject to the Bank of Italy's supervision. Furthermore, a recent norm $(1214,23$ December 2011) gives to private and public entities and large non-financial enterprises the possibility to participate in the capital of the supervised Confidi.

The survey by Unioncamere Lombardia illustrates the process of consolidation: in 2011 the 10 largest Confidi (all 107-type schemes) accounted for about $80 \%$ of the guarantee market, and the largest three accounted for about half of it. On the other hand, the small Confidi (with a portfolio of guarantees below EUR 25 million) accounted for only 3.9\% of the guarantee stock, although they represented one third of the surveyed sample.

The ongoing polarisation in the system, with on the one hand large supervised players and on the other hand small and fragmented unsupervised schemes, is evident also in the data concerning the number of clients and the size of the guarantees. The smallest Confidi (with a portfolio of guarantees below EUR 15 million) serve on average 1700 associated firms and the average amount of the existing guarantees is EUR 5 837. On the other hand, the largest Confidi (with a portfolio of guarantees above EUR 300 million) count on 20000 associated firms on average and the average amount of guarantees granted is above EUR 30 000. This latter evidence suggests that the largest schemes have not evolved into guarantee services for larger firms. Rather, it appears that they have become catalytic actors, attracting a large number of SMEs, sometimes also through aggressive marketing strategies and a significant expansion of their commercial network to categories of firms that were not typically associated to these schemes (Unioncamere Lombardia, 2011).

The increase in scale and outreach of the Confidi is also, at least in part, a consequence of the crisis, and the role they have played to ensure liquidity was maintained for SMEs. This was common to other countries and regions characterised by established guarantee systems. Over 2008-2010, in order to offset the credit crunch and ease SME access to finance, in many cases new elements were added to guarantee schemes and in others new instruments were created outside the traditional guarantee programmes (OECD, 2010; OECD 2012). Relevant changes included increasing the coverage of guarantees and making the eligibility criteria for guarantees less stringent, in terms of firm size and in terms of the use of the loan. In Italy, crafts firm, which had been excluded from loan guarantees provided by the public SME Guarantee Fund before the crisis, were allowed to apply for guarantees.

The institutions in the region have also developed responses to the crisis and supported their implementation through new funding targeted to guarantee schemes. A fund, "Confiducia", was created in 2009 by the regional government, Unioncamere Lombardia, and the chambers of commerce, to limit the effects of the crisis and ease access to finance by regional SMEs. The fund amounted to EUR 57 million, of which the greatest share (EUR 51 million) was assigned to counter-guarantee or co-guarantee the guarantees by the Confidi affiliated to Federfidia (the second-tier regional scheme), and a minor part (EUR 6 million) was assigned to support the Confidi outside of the Federfidi 
coverage. The operations of the Fund terminated on 31 March 2011, having supported 14500 financing procedures, amounting to more than EUR 1 billion.

The use of the guarantee schemes as a countercyclical instrument has brought about a greater degree of insolvency, which has contributed to increase the cost burden on the existing institutions. This adds to the increased administrative costs incurred to comply with the more stringent supervision requirements. This higher cost of operation makes efficiency ever more important. Greater efficiency should be ensured by the increased scale of Confidi and limit the transfer of these higher administrative costs to the prices of the services provided.

However, the change in scale and scope of these schemes demands also an upgrade of technical and organisational competences and the development of new skills and strategies, typically a weakness in the Italian fragmented guarantee system (De Vincentiis and Nicolai, 2012). If a change in scale and procedures is needed, to comply with the new regulation and compete in a changing market, on the other hand a concern exists that the greater scale may come at the cost of loosening the relationship these schemes have with SMEs and their local systems. In fact, the 107-type Confidi are already operating at a regional or national scale, beyond the traditional sectoral or territorial boundaries.

The panel interviews with local institutions and experts highlighted that this difficult balance, between efficiency and territorial proximity, could be best met by further rationalising the current system and structuring a strong credit guarantee filiere, which includes first-tier schemes that are close to the firms and the local systems, second-tier regional or intersectoral schemes, such as Federfidi Lombarda, which provide mainly counter-guarantees or co-guarantees to the first level and are the main counterpart of public institutions for the allocation of public resources to the guarantee system, and a well established national fund, along the model of the Central Guarantee Fund. The measures and actions taken in the Lombardy region seem to be consistent with this would-be model.

However, it seems that the market is not yet expressing a preference for greater scale and supervised operators or more structured multi-tier systems. Unioncamere Lombardia (2011) highlights that, indeed, non supervised players are currently taking advantage of their lower costs and less stringent requirements to provide better priced guarantees and less cumbersome procedures. Also, the banking system does not appear to fully recognise a "premium" for supervised Confidi or to engage these schemes more frequently into credit assessment, particularly in the case of SMEs' difficulties or insolvencies. At the same, Unioncamere Lombardia (2011) recognises that the boards and managers of 107-type Confidi are yet to fully exploit the possibilities implied by the new regulation and to broaden the range of services provided.

If the regional credit market is highly dense and articulated, the market for risk capital, which should support new entrepreneurs and SME growth, is significantly less mature and segmented. The reliance on debt characterises Italian SMEs overall, and the enterprises in Lombardy are no exception. In the case of micro and small firms, the low degree of capitalisation represents a serious impediment to invest and grow and makes these firms highly vulnerable to downturns in credit markets. The small scale and limited sophistication of the equity market limits in particular innovative entrepreneurship and highly dynamic firms. In fact, firms with established business models as well as those with low to moderate growth prospects typically can access financing through a) bank credit, b) asset-based financing (leasing, factoring etc.), c) official loans and guarantees. On the other hand, these traditional techniques are of only limited applicability in the financing of high risk/high potential growth firms and for newer and innovative companies.

The small scale of the risk capital market in the region reflects Italy's limited progress in this area. Indeed, within the Italian framework, Lombardy is the leading region in the development of 
venture and growth capital markets. In 2007, 140 operators were active in the Italian risk capital market, accounting for an investment of EUR 4197 million. Lombardy accounted for $78 \%$ of operators, $30 \%$ of operations and $51 \%$ of amount invested. The leadership of Lombardy was maintained throughout the crisis and as the equity market recovered, although at closer distance with respect to the other regions. In 2011 the region accounted for $26 \%$ of operations and $35 \%$ of the amounts invested, followed by Veneto (25\%), Tuscany (9\%) and Emilia Romagna (7\%) (AIFI data ${ }^{10}$ ).

As far as the financing of start-ups is concerned, the regional government and institutions have launched several initiatives, which foster the creation of new enterprises through advice, training and financial support. Often these actions count on the co-investment by local players, such as the Chambers of Commerce, and the European Union. Recent initiatives include the Start-up and START programmes, launched in 2011. The Start-up programme mainly targets young people, women and disadvantaged workers and aims to create employer firms, which have the potential to generate significant levels of employment. The programme is funded with EUR 50 million and is expected to invest an average of EUR 50000 in about 400-500 new firms. The START programme intends to provide support in the form of training, mentoring and funding for about 2000 new firms to be created $^{11}$.

Both these initiatives follow programmes that operated over the earlier decade. However, whereas monitoring of access to these programmes has been conducted, no systematic evaluation of their additionality and sustainability was carried out before new initiatives were launched.

The region has also developed instruments that address the problem of under-capitalisation in the third sector. The support to broaden the range of financing opportunities for cooperatives is expected to lead to more jobs and better services. In 2008, in the framework of the JEREMIE programme, Finlombarda, entirely owned by the region, has created a EUR 40 million scheme, funded at $50 \%$ by EU Structural Funds and at 50\% by banks, to make loans of EUR 4000 to individuals, for investment in the shares of their cooperative. The beneficiary, however, should stay in the cooperative for at least five years. Half of the loan is repaid free of interest at the end of the period whereas the other half is repaid to the participating bank at a fixed interest rate. The scheme benefited individuals at 400 cooperatives, out of a total of 600 in the region.

\section{OECD Survey evidence}

The survey indicates widespread knowledge and use of credit instruments, and credit guarantees in particular among Lombardy's SMEs, whereas rather diversified views are expressed on the diffusion of risk capital and the initiatives supporting start-up funding.

Credit guarantee systems are recognized as an important tool in the system, across the range of institutions interviewed. They are generally believed to address the needs of SMEs, but some respondents find there are impediments to SME access, related to lack of knowledge or the amount of financing needed, which may be closer to what is provided by microfinance institutions than by the banking system. As far as existing microcredit facilities are concerned, some regional stakeholders highlight the lack of communication about them or the occasional occurrence of support initiatives.

It is common view that risk capital is not largely available in the territory or that SMEs have difficulties in accessing it. A few examples however are cited of successful venture capital initiatives,

\footnotetext{
$10 \quad$ See www.aifi.it.

11 See Chapter 3 on New Enterprise Creation for more details on these programmes.
} 
supported by the Chambers of Commerce. Also, there is little knowledge about business angel activity in the region, with the exception of some pilot schemes that encourage and promote the creation of business angel networks.

If the market for equity is perceived to be small or regional stakeholders know little about its expansion, on the other hand, knowledge about public start-up funding is diffused, particularly among public research organizations, which often provide assistance to access it. Positive assessment was expressed by some interviewees on the contribution to new business creation by the numerous regional programmes, such as the regional initiative START. However, the concern is commonly expressed that there exist financial support schemes for innovative enterprises, but the firms in the territory have difficulties in accessing them. The main difficulties for SMEs or entrepreneurs in accessing equity funding and financing for innovative projects are the lack of knowledge about the service provided and the stringent eligibility criteria. In some cases distrust by SMEs is also cited as an impediment to their access to funding and instruments.

There is full agreement that investment readiness programmes, which seek to increase the SMEs' demand for equity finance, addressing equity aversion, investibility and presentational issues, are not available for SMEs in the region.

The knowledge about financial educational/cultural programmes differs across institutions, with similar shares of those that believe these programmes are not available or of difficult access for SMEs and others that maintain that the access to these types of programmes is increasing and more subjects are engaged in financial education.

\section{Challenges and opportunities}

The Lombardy region is the main platform for financial services in Italy, characterised by a high density of financial intermediaries and a well-established network of institutions that provide financial services to SMEs, such as mutual guarantee schemes (Confidi). Furthermore, the region exhibits a relatively high degree of internationalisation in the financial sector, being the main destination of investment by foreign banks that operate in Italy, represents the main market for private equity in the country, and the capital city of the region, Milan, hosts one of the most important stock exchanges in Europe.

The following paragraphs highlight key challenges that this articulated financial system faces, in the aftermath of the most severe global financial crisis in decades, and, in a long-term perspective, to address structural gaps in SME and entrepreneurship financing, within a reformed financial environment. The section then comments on the opportunities for deepening the regional financial system, building on historical strengths, but also adopting innovative solutions to address longstanding weaknesses and most recent threats.

\section{Challenges}

Business financing conditions deteriorated as a consequence of the 2008-09 global financial and economic crisis, in Lombardy as in many other European regions. The relatively articulated financial system, especially the dense network of guarantee schemes (Confidi), helped to limit the impact of the diffused credit crunch on SMEs. However, as recovery remains uncertain and financial institutions take action to respond to the requirements of Basel III, access to finance by SMEs is likely to be negatively affected over the short-medium term. The risk exists that, in the region, viable SMEs with sound projects may not be able to access the financing they need to survive the stormy times and 
grow. The effects of the credit constraints are exacerbated by the over-reliance on debt by SMEs and the limited availability of alternative instruments.

The regional government has responded to the crisis mainly with measures that supported the existing network of SME-oriented schemes and institutions. Mutual guarantee schemes have played a relevant role in this regard, as one of the pillars of the SME finance architecture in Lombardy. Also cooperative banks (BCC) strengthened their efforts to support the credit to micro and small businesses in the aftermath of the crisis, increasing the number of units in the territory and the amount of credit granted to families and entrepreneurs.

However, the use of debt financing through existing channels as the key counter-cyclical instrument brings about some challenges. In the case of mutual schemes, for instance, this has resulted in a greater degree of insolvency, which adds to the increased administrative costs these schemes experience to comply with the more stringent requirements from new regulation. The increase in scale of several Confidi, as well as the creation of a regional second-tier intersectoral scheme (Federfidi Lombarda), respond to the need to achieve greater efficiency and improve risk-hedging. In the light of this increase in scale, the Confidi system faces the challenge to maintain - or not to lose - the close linkages with SMEs and entrepreneurs and the in-depth knowledge of the business sector that have represented their traditional strength. This is also the case for traditional financial intermediaries, such as the main bank groups, which have experienced a significant process of consolidation. In other terms, there seems to emerge a trade-off between proximity and scale in the provision of financial services to SMEs. The way in which the existing institutions will address this trade-off is a highly relevant issue for the evolution of business opportunities in the region.

For instance, the Confidi system is responding to this challenge by accelerating the reorganisation of the guarantee filiere, along a multi-layer model, with a fewer larger supervised Confidi and an upper multi-sectoral institution. A related challenge is now the response by other players in the market to this reformed system. Banks, for instance, do not appear yet to recognise a 'premium' to supervised Confidi, which leaves room to smaller schemes to compete on costs. A cost-based competition may not be beneficial to the sector, which, on the other hand, requires at this time a significant investment in training and new expertise.

The large focus of the anti-crisis measures on debt instruments reflects - and further strengthens the prominent role of debt financing for the region's SME sector. The thin capitalisation of SMEs represents a long-standing weakness that the crisis has made more evident. The equity investment by entrepreneurs remains small and the range of financing instruments available to SMEs is rather narrow, especially when compared with the alternative financing instruments being developed and supported by regional policy makers in other dynamic areas of Europe (see learning models in Annex I for a few examples). The equity market for start-ups and SMEs is small and other financing instruments, like mezzanine finance, that could serve the needs of high-growth firms or firms undergoing relevant transition, such as change of ownership, have found little application in the region. At the same time, the use of more sophisticated financing instruments, different from traditional debt, is limited by the lack of awareness and understanding by entrepreneurs of a broader range of financial/insurance products and concepts that could serve the needs of the company at different stages of its life cycle. This adds to the traditional aversion by entrepreneurs to equity-like instruments, which would demand relinquishing control. Investment readiness programmes, which seek to increase the demand for equity finance by SMEs, addressing also their aversion to external investors, are not developed in the region. 


\section{Opportunities}

The high density of the financial system and the traditional engagement of the business sector in developing schemes that support SMEs' access to finance represent important strengths for the region, from which opportunities can arise, to address the current challenges and to broaden the financing instruments and services available to SMEs. The traditional mutual guarantee schemes and cooperative banks combine with large scale financial institutions and the most important national platform for equity. Although further rationalisation and consolidation are expected in the near future, the variety of players in the financial sector is an asset. The actors are in play that could provide more diverse services and products to respond to diversified needs of SMEs and entrepreneurs.

For instance, in the future, Confidi may play a greater role in supporting the internationalisation of SMEs, partnering with the other players in the systems, such as the Chambers of Commerce, which provide services to SMEs operating across borders. The extended system of credit guarantees could also take a more active role in supporting start-ups and the development of new enterprises. Some progress has been recently made in this direction. For instance, Federfidi Lombarda is contributing to the financing of start-ups, counter-guaranteed by the European Investment Fund under the Framework Programme for Competitiveness and Innovation (2007-2013). This role of the Confidi system could be strengthened by extending the guarantee instrument to risk capital, as experimented by guarantee schemes in other European countries, like France.

The region's articulated system of education and research provides an important pool of qualified human capital, competencies and expertise, which could feed into the financial system oriented to service SMEs and entrepreneurs, supporting the evolution of existing institutions, the development of new services and products. The pool of qualified human capital represents an opportunity also for SMEs, which need to increase their competences on financing options in a rapidly changing environment, and improve understanding of how their different needs may be served by different instruments and players.

\section{Conclusions and recommendations}

Business finance in the Lombardy region is largely structured in debt financing instruments, provided by a dense network of diverse financial institutions, which include large bank groups, cooperative banks and guarantee schemes. The regional government has been sustaining this system with numerous programmes, addressing specific financing gaps, as in the case of start -ups and innovative firms, and, in the recent difficult times, strengthening the capacity of the existing institutions to ease SMEs' credit constraints.

As the SBA recommends, facilitating SMEs' access to finance has been a driving rationale of actions by policy makers and other regional stakeholders. Also, the regional government has addressed the issue of timely payments in commercial transactions, another relevant dimension in the SBA principles, and has improved, in the current difficult context, payment performance, reducing the strain on SMEs' cash flow. However, although the region is an example of good practice in the Italian framework, the average delay in payment is still high if compared with other European countries.

SMEs' deleveraging and equity investments represent, on the other hand, areas in which substantial improvement is needed. The SBA encourages improvements in the field of venture capital and targeted measures to increase the awareness of existing and potential investors about the opportunities offered by SMEs and new firms. 


\section{Broaden the range of financing instruments available to SMEs}

The SME financial system in the region is strongly characterised by debt financing. The range of instruments available to SMEs is rather narrow and does not respond to diversified needs of firms that have different growth prospects or are at different stages in their life cycle. Especially, the finance available for innovative start-ups is rather limited, in spite of the numerous public programmes launched in this area in recent years. The market for risk capital is significantly less mature and segmented that the credit market. The small scale and limited sophistication of the equity market limits in particular innovative entrepreneurship and highly dynamic firms. There is a need to support more extensively the development of risk capital for new and innovative firms. The development of financing instruments alternative to traditional debt (e.g. mezzanine finance) would also benefit the broader SME sector, allowing for deleveraging and greater capitalisation. Alternative non-debt instruments could also support more effectively firms' transitions, such as change of ownership or management.

\section{Encourage the participation by the private sector in the financing of innovative firms}

The (increasing) budget constraints limit the capacity of the public administration to generate scale in the financing of innovative ventures. The co-financing by the public sector, which can bring in also important advantages in terms of knowledge and linkages with other activities, is all the more needed for the sustainability of these programmes and for achieving a sufficiently large scale. The engagement of industry leaders in equity funding programs for innovative start-ups or high-growth SMEs could contribute to these objectives, but it has been little explored in the region. Indeed, international experience shows that large groups may have an interest in cooperating with the public sector to encourage innovation-based entrepreneurship, increase R\&D orientation by SMEs and improve the overall innovative environment.

\section{Improve financial education and investment readiness}

The adoption by SMEs of instruments alternative to traditional debt is limited by their financial competencies, but also by the lack of interest or awareness about opportunities by potential investors. Financial education and investment readiness programme can help to strengthen the demand and supply side of the market. To enhance investment readiness amongst the SME population all of the components that influence the quantity and the quality of demand for equity finance should be addressed, including equity aversion, investability and presentational issues.

\section{Sustain credit guarantee schemes in achieving greater efficiency while maintaining territorial proximity}

Mutual guarantee schemes (Confidi) are a key component in the region's financial system servicing SMEs. The recent reforms, including Basel III, are inducing a rapid reorganisation in this sector. Consolidation is taking place and supervised schemes already represent the majority of credit guarantee providers, although the guarantee landscape is still highly fragmented, with smaller schemes taking advantage of their proximity to target firms and lower operating costs. The region should support the process of reorganisation and rationalisation in the sector, which is resulting into a multilayer guarantee system, in which second-tier schemes provide co- or counter-guarantees to first-tier mutual schemes across industries. The vertical structuring of the filiere, with the central guarantee fund at the upper level, should allow for greater efficiency and risk hedging, while maintaining, at the lower level, the territorial proximity that has historically represented a strength for the mutual guarantee sector. This transition however demands competence upgrading, which can be favoured by training and attraction of qualified human capital into the sector. 
Favour a more active role by Confidi in the development of new entrepreneurship and the support of SMEs' innovation and internationalisation

In recent years, credit guarantee schemes in the region have broadened their services, contributing also to the financing of start-ups. Relevant initiatives have been taken in cooperation with other entities that provided specific expertise as well as co- or counter-guarantees, sharing risk and allowing greater leverage. The role of guarantee schemes in entrepreneurship support and SME development should be further strengthened. In particular, measures should be taken to facilitate the extension of guarantee services to other type of financing, as experimented in several European regions, including risk capital and export financing.

Strengthen progress towards timely payments in commercial transactions in particular in payments owed by public administration to SMEs

Reducing late payments is a priority in the Small Business Act. Payment delays can severely exacerbate small businesses' cash flow problems, especially at a time of credit constraint and sluggish demand. Payment delays by the public administration represent a serious hurdle for SMEs in Italy, where, on average, in 2011, firms had to wait 180 days to receive a payment. Over the last years, the Lombardy region has improved its payment performance and has launched initiatives to support SMEs that meet difficulties due to late payments, in collaboration with the chambers of commerce and the banking sector. The regions should strengthen its efforts to combat late payment and limit its effects on SMEs' solvency and performance, building on the positive outcomes of recent initiatives. 


\section{CHAPTER 6: CONCLUSIONS AND POLICY RECOMMENDATIONS}

\section{Lombardy region and its entrepreneurial structure}

Lombardy, as well as Italy, is facing a process of structural economic transformation that started slowly already more than one decade ago, due to the growing process of market globalization that progressively changed the basics of the consolidated competitive advantage of the regional economy. Such an evolving context for developments regionally and nationally has turned into a remarkably faster pace, fuelled by the global downturn, which places more pressure on local developments and the issues that shape competitiveness.

The region is endowed with many actors in the economic system and a plethora of support agencies and associations focusing on small businesses, which in fact are the backbone of the regional productive structure (based on 823268 companies with more than 4.3 million employees, 2009 figures). This creates a landscape for SMEs that can be confusing with a perception of scattered and overlapping initiatives. When this occurs it is often accompanied with a lack of focus on change outcomes for net effect at regional level.

The past resilience of the small business activity has been mainly based on continuous product improvements. With the openness of markets and truly global competition, there is an increasing requirement to compete at the higher value market segments and demonstrate an ability to innovate and internationalise. Policy improvements can stimulate this change and a sound system of agencies and players devoted to SME assistance at territorial level can be an essential part of the practical delivery process.

In fact, like many regions across the OECD, Lombardy has yet to organise and mobilise the different actors into an inclusive framework that spurs growth and development. Governance development has not kept pace with economic development and global competitiveness challenges. As a consequence, there are issues of overlapping responsibilities, incomplete networks and underdeveloped assets.

The aforementioned given context is such that local SMEs often struggle to receive, but also to perceive the effective usefulness of assistance other than the one oriented to tackle immediate short term needs - e.g. access to funding - and an initiative introducing change is needed in the top areas of priority, which are internationalisation and innovation. The supply of services to SMEs faces many challenges at a grass roots level to stimulate more sophisticated demand based around a fundamental understanding of the factors critical for sustainable success and growth. Reinforcing the key messages through policies that set the framework environment for business and encourage networking can assist and build around the SBA principles.

SMEs are flexible and can adapt quickly to create new value but scaling this up in a highly competitive global context is a new challenge for the region, especially as many SME owners approach retirement with a slowdown in growth aspirations and without a clear succession or exit plan. A previous OECD study on the Milan metropolitan area warned of the need for rapid action on 
two fronts, innovation and governance, and to this must be added key challenges of access to finance and internationalisation.

In short, the results of the OECD present study lead to the conclusion that Lombardy, the most prominent region of Italy in terms of economy and industry and not only, is facing a crucial turning point that stems from the need of governing a structural change of its industrial and economic sector, based on small businesses, that was already perceivable over the last decade and that the current economic downturn turned into an urgent priority. The region is endowed with assets, resources and energies that enable tackling such a challenge, but prompt action is needed. The current chapter offers a set of policy recommendations based on the research exercise.

\section{Business Environment and SME Network}

There is considerable sub-regional diversity in SME economic activity in Lombardy. The province of Milan is home to multinational and financial companies, educational and health institutions and research centres. Varese, Como, Lecco, Monza e Brianza, Bergamo all have a strong manufacturing sector but also a high proportion of service employment. Lodi and Brescia feature both manufacturing and agriculture, while the province of Sondrio, as well as the three provinces in the plains (Cremona, Pavia, and Mantua) have a strong agricultural sector. In such a multifaceted context the crucial challenge is to shift from current prevailing industrial structure - mostly devoted to traditional and often mature sectors, even if interesting and promising advanced segments are already present - to a services and knowledge intensive economy. Dealing with such a challenge implies a number of key factors.

An effective, long-term, sound and well structured policy is recommended in order to establish a business environment conducive to the progressive change of paradigm, identifying the new and emerging competitive factors of the regional economy and paving the way to that new sustainable development perspective. The persisting although residually competitive "traditional" businesses should be maintained in the short-term in order to keep regional economy going on and pulling the recovery from the crisis but at the same time, being conscious that most of them will not survive as such for a long time, actions for fostering the new sectors shall be conceived and put in place. Such actions shall be conceived and tailored in order to take advantage of the diversified and complementary structure of the local economies of the Region and of the relevant specific potentials of change embedded in the local peculiarities.

Most SMEs are family-owned business facing the problem of inter-generational firm succession and transmission. Such a passage is at the same time a threat to the survival of the specific business but also brings opportunities to turn it into a more innovative company and able to expand into new markets and to find new growth paths. However, in order to minimize the risk and enable the achievement of such a development process through the generational change, the process should be addressed by targeted programmes aimed at supporting and steering such changes.

All of the above, addressing the change of paradigm, implies the need for an effective facilitation of the overall process. In fact the process is already going on and will further develop. In any case, the real issue is related to the transition costs, social and economic, for the regional system and the local sub-systems. In order to minimize such costs a clear governance scheme of the transformation of the regional industrial structure is required where the new businesses will gradually replace the old ones. 
Some of the key elements to be considered in conceiving the scheme:

- From spontaneous networking to a strategy oriented one; the region is rich in the number of actors dealing with SMEs development and their networks have been mostly spontaneously developing over time (SME districts and clusters, service centres, techno-parks, agencies, R\&D centres, etc.). Still there is an overlap in competences, roles, functions, services and on the other hand small companies find it difficult to find the most suitable service provider able to deal with their specific needs because of a lack of effective coordination and lack of shared vision. Such operating conditions call for an improved common and strategy oriented networking structure at local and regional levels.

- A number of policies and measures have been conceived and implemented over the last years, channelling regional, national and European funds and aimed at supporting the development of small businesses. In recent years some notable efforts have been done at regional and local levels in order to improve the effectiveness and coordination of such a set of actions (good examples of such an effort being the appointment of "Mr SMEs" and the experience of the SBALombardiaLAB,). However, a weak learning and steering structure was detected during the study, due to the lack of effective monitoring and evaluation tools and instruments able to assess the progress and the results achieved through the implementation of those policies and measures. Such a structure is highly recommended in order to enhance the ability to learn from the experiences and to capitalise on the positive lessons gained over the years. A strategy oriented approach needs to be backed by a better evaluation system, in order to achieve a substantial and attainable improvement in the coordination and networking of the number of actors which play a determining role in SME development (development agencies, technoparks, financial institutions, universities, training centres, etc.).

- Moreover such an improved networking and advanced learning approach is a precondition for pushing for a market shift towards growing world economies and to foster internationalisation: Lombardy economy and industry has a strong orientation to export but is still addressing "mature", consolidated and often declining markets (e.g. United States and European countries). Establishing a clear strategy and a better market intelligence capability is recommended in order to strengthen the penetration into growing markets that are expected to further develop over the next years and decades (the BRIC economies). In the regional system, there are actors that already play a prominent role in the internationalisation, recognised at regional, national and international levels, such as PROMOS, the Special Agency of the Milan Chamber of Commerce for the promotion of international activities. An improvement in networking and a stronger common strategy addressing internationalisation is needed and would undoubtedly benefit companies based on the region, enhancing their capacity to compete in these markets.

\section{Entrepreneurship and SME Workforce skills}

Skilled human resources and entrepreneurship culture are crucial factors for confronting the structural change that the Lombardy economy is facing; the regional system must rely on a widespread educational system able to generate and update such a culture.

Regional communities are endowed with a widespread working oriented attitude and spontaneous entrepreneurial spirit that characterise the people. Such an attitude has been and still is the reason and the main factor for the existing strong regional economy: imitative behaviour, good opportunities of employment that attract qualified people from outside including immigrants, as well as a well 
developed educational infrastructure, at all levels - primary, secondary, tertiary - resulted in a positive combination for generating capabilities the companies needed and still need for their development.

SMEs of the region are usually restricted in their ability and willingness either to undertake formalised training and qualification programmes for their workforce or to pay for systematic training, even though their attitude shows signals of change, still most of the training inside the company is just oriented to a learning by doing approach.

Since the challenge Lombardy faces is to undertake a substantial change in the economic and industrial development structure, the unavoidable course is to undertake an important evolution of the way education and training are delivered in order to build a new entrepreneurial mindset in the people at all levels. The institutions responsible for education and training must incorporate and disseminate the new entrepreneurial culture and improve their ability to interact with the other economic actors, starting from the small companies.

In the past the traditional business culture was disseminated mostly informally, according to a kind of process osmosis, facilitated by the predominant common culture. Since what is now needed is a leap forward, aimed at generating a new entrepreneurial culture, a specific and renovated capacity to establish that culture requires deliberate and coordinated action. At the same time, there is a need of substantial improvement of the ability of the educational structures and institutions to act according to a more coordinated approach and achieving a more explicit perspective towards small business and entrepreneurship.

That should necessarily be the result of a converging combination of actions, part of the overall comprehensive regional strategy of SME development, to be aligned to SBA principles. Such a strategy shall mobilize the relevant programmes, measures and actions of the region in order to facilitate the dissemination and the establishment of a new entrepreneurial culture and a positive attitude, from all the interested actors, towards continuous improvement and qualification of skills that should include:

- Involving higher education institutions for improving their capacity to target curricula and courses aligned with the new entrepreneurial culture, consistent to SBA principles, and with a focus on the actual needs of new SMEs.

- Involving Vocational Training institutes, for orienting their new skills generation not only addressing the current demand for qualified workforce of existing companies but also stimulating and inducing a cultural change open to new businesses, in order to build capabilities that, taking advantage of the actual local culture, are already open to the new development path.

- Considering the crucial role of life long training and improved retraining programmes in addressing SME employees at all levels (workers, managers, entrepreneurs, professionals) and stimulating the adoption of a new culture of small business oriented to a more open attitude towards continuous improvement of skills.

- Defining training and education programmes targeting specific groups that require further regional policy attention and programmes of support, such as youth, women and migrants: the first two targets have an unemployment rate significantly higher than the average in Lombardy, whereas the immigrants are a significantly increasing resource in the regional labour market. 
- To foster the interaction of educational institutions with enterprises, conceiving new cooperation approaches and tools aimed at favouring the design of training courses targeting SMEs needs, exchanges of practices, facilitating internships and temporary work experiences, etc.; the region has already undertaken novel schemes and approaches (e.g. the dote or voucher system) oriented to facilitating such new cooperative actions.

- On the side of demand, to stimulate the evolution of attitude of SME towards education and training and their ability to act effectively with training and education institutions.

\section{New enterprise creation}

Next to the improved capacity to establish a sound regional networked system where small businesses can flourish and provided that in such a system skilled workforce and enhanced entrepreneurial attitude is built, the effective capacity to generate new businesses is a notable an prime priority. In fact that is a further key constituent required in order to address the shift from consolidated traditional manufacturing toward future competitive SME.

Two of the main reasons for focusing new business creation include:

- $\quad$ reverting the current trend where business mortality exceeds the birth rate that is affecting the regional industrial sector, currently neither mitigated nor counterbalanced by the increase of the average size of existing companies, in terms of number of employees;

- $\quad$ support the progressive change of the typology of the companies, to be fostered in order to induce a twofold change in the SME regional structure: in the traditional sectors of regional economy, shifting from old and "obsolete" firms to more innovative ones; investing in start ups and new promising business in sectors and niches where Lombardy competitiveness should invest and rely for its future prosperity.

\section{Knowledge networks and innovation}

OECD emphasises the need for regions to move up the value chain in order to compete and prosper in the global marketplace. In order to do this, SMEs must have ready access to external sources of information, knowledge and assistance to build their own capacity and ability to reach growth markets. Collaborative innovation works best: greater inter firm collaboration and exchange within networks including universities, research institutes and agencies are essential.

The level of research and innovation in Lombardy has been consistently high (e.g. 267 research structures inside private companies, 182 leading companies in innovation, about 1 out of 4 patents are generated in Lombardy, large number - about 60 - structures providing services for innovation and new business).

Knowledge and business networks are underutilised assets in Lombardy: there is the need, with a strong policy driven approach to stimulate new relationships, induce and facilitate commercially oriented knowledge search and innovative activities and thus create new value and growth. There are conditions in place for pursuing further SME development, based on innovation and addressing new sectors stemming from significant knowledge intensive clusters (e.g. bio-tech, agriculture and agrifood, green energy, design, creative sectors). 
At the policy level, while focusing the potential of innovation in existing businesses and or creating new innovative companies, some specific actions are to be recommended, stemming from the analysis carried out in the present study:

- Reinforce links between SMEs and academic and research institutions to distribute knowledge and incubate innovation.

- Favour and facilitate a closer link and interaction between SME and large companies developing networking, since large companies - including multinational ones - can play a relevant role in pushing small businesses towards innovation.

- Reinforce and strategically take up public private consultations (PPCs) on a permanent basis, considered as a key means for reinforcing the capacity of networking among government, enterprise and academy, defining and clarifying their respective synergic roles and levering greater productive collaboration.

- Make the accessibility of innovation support services for SMEs easier (research facilities, R\&D funding, advice services, etc.).

- Pursue the alignment, more effective networking and rationalisation of the regional agencies and partners active in stimulating innovation and development of knowledge-based undertakings.

- Act pursuing the internationalisation of SMEs as a driver for inducing innovation: getting over mere exports and trading means opening new markets but also source of ideas, establishing new collaborations and businesses. Additionally it gives the opportunity for learning for others' experience (e.g. the Northern European countries experience, such as Serve scheme and TEKES in Finland, Vinnova in Sweden).

\section{Access to Finance}

The "SME financing gap" is the object of a long-standing debate, which has been revived by the recent financial crisis. The gap describes the situation where a sizeable share of economically significant SMEs cannot obtain financing from banks, capital markets or other suppliers of finance. In other words, some SMEs and entrepreneurs that have the capability to use funds productively if they were available do not have access to those funds (OECD, 2006).

The Lombardy regional financial system is characterised by a high density of financial intermediaries, which persists in spite of a process of consolidation that has been taking place since the 1990s and serve not just the regional economy but act as "financial hub" for the national economy: $23.5 \%$ of Italian banks had their legal seat in Lombardy and the region hosted $79 \%$ of affiliates of foreign banks that are active in Italy (Schena, 2010). At the same time, the region accounts for a non marginal share (10.8\%) of Italian credit cooperative banks (Banche di Credito Cooperativo - BCCs), which grant loans to all economic categories represented among the owners, with a relevant role in micro and small businesses. Last but not least the extended network of Mutual Guarantee Schemes (Confidi) plays a key role in the Lombardy's system of SME financing: 238000 firms are associated with 31 regional Confidi (2011 Unioncamere Lombardia survey).

If the regional credit market is highly dense and articulated, the market for risk capital, which should support new entrepreneurs and SME growth, is significantly less mature and segmented. 
In order to facilitate the access to finance for SMEs and in particular to support them in the different stages of their lifecycle there the need of widening and diversifying the range of financial services. Most of the financial instruments are already often available but their development, adoption and use must further pursued: good examples are risk capital (even considering that performances of venture capital dropped consistently in the last years due to the downturn), business angels, mezzanine finance and other instruments alternative to the traditional credit.

Such an action, addressing the diversification of financial services, should proceed in parallel to the maintaining and improving of the current schemes, in particular the mutual guarantee schemes, which performance and reorganisation - already going on - should be supported, in order to accomplish with the new standards required by the recent financial sector reforms and gaining greater efficiency. Simultaneously keeping the territorial proximity of the Confidi network important to target firms, the current offer ensures to undoubtedly facilitate the accessibility for smaller businesses.

Involvement of the private sector in financing innovative businesses is a further relevant option to be pursued in order to complement the public funding that is facing increasing constraints stemming from the current downturn. New forms of cooperation between public and private investors shall be pursued as they are also consistent to the new EU cohesion policy regulations for 2014-2020.

\section{Final remarks}

Lombardy region attained a high level of development and standard of living and counts on a vibrant economy that has shown a good level of resilience is coping with the impact of the international persisting crisis, apparently preventing major damages so far. SMEs played and still have a key role in local economies of the region, which is characterised by highly diversified local structure.

The regional economy is undergoing a dramatic structural change that already started years before the eruption of the downturn and has been mainly provoked by a combination of globalisation and of structural changes in the local socio-economic system. The crisis basically changed the pace of the process inducing a remarkable acceleration. IT's rather clear that such a change requires a clear steering capacity and a consistent policy framework to be tackled successfully. "Doing business as usual" and rest on its laurels attitude cannot considered as an option, since the costs of the "laissaiz faire" would be most likely unbearably high.

The regional SMEs are in the front line of such a change and a clear and specific policy is recommendable. Various are the assets, both tangible and intangible, the regional system is endowed with that can most often represent a potential for SME development not yet fully exploited. Furthermore a number of experiences (programmes, schemes, facilities, measures) aimed at supporting small businesses - in most if not all their areas of interest and need - have been developed both at regional and at local level. The number of these experiences and the presence of such assets, combined with a somehow weak strategic coordination scheme, has been often perceived, during the study, in a cumbersome way of operating, in fact hindering the effectiveness of the overall SME supporting action undertaken in Lombardy region.

In all such remarkable pre-existing endowment lays most of the potential resources for designing future effective actions. For that to happen however is crucial to work on substantial improvements in coordination, cooperation and synergies among the various actors and initiatives dealing with SME, on enhancing the learning and capitalisation ability through a more effective and systematic monitoring and evaluation and eventually on conceiving a consistent medium-long term regional policy addressing specifically SMEs and a comprehensive entrepreneurial strategy. 
Two main reference points and opportunities are given nowadays that can help in undertaking such a strategic effort addressing local entrepreneurship and enterprise creation in Lombardy region:

1. The SBA review of 2011 proposes a set of new actions aiming to respond to the challenges resulting from the economic crisis, and further developing existing SBA actions in line with the Europe 2020 strategy:

- making smart regulation a reality for European SMEs;

- paying specific attention to SMEs' financing needs;

- taking a broad-based approach to enhancing market access for SMEs;

- helping SMEs to contribute to a resource-efficient economy;

- promoting entrepreneurship, job creation and inclusive growth.

2. The European cohesion policy is currently in the process to be re-programmed for 20142020 period: negotiations are quite advanced for the new regulations as well as for the financial framework. The cohesion policy will provide a relevant source of funding, through EC structural funds, in the future for SME development. Worth to be highlighted that, among the given priorities for European most developed regions, like Lombardy, are defined:

- $\quad$ strengthening research, technological development and innovation;

- enhancing the competitiveness of small and medium-sized enterprises.

To conclude, given the situation of SMEs in Lombardy region as it has been analysed in the present study, highlighted the challenges the entrepreneurial local system is called to cope with in the current international system and introduced a set of recommendations how to approach a comprehensive relevant policy, the following box outlines the main consideration which have been drawn in the light of the Small Business Act principles.

\section{Box 7. SBA main considerations}

P.1. Create an environment in which entrepreneurs and family businesses can thrive

- The Lombardy region does well in terms of firm density, though this is declining and the firm death rate has exceeded the birth rate in recent years. The issue of family business and transmission is a serious and growing concern which must be managed effectively.

- The region is generally entrepreneurial, though more could be done in the area of entrepreneurship learning and preparation at all levels of the education and skills development system.

- The structure and cultural emphasis on micro and family businesses in the region means that many challenges are deep rooted in Lombardy. Changing culture and structure takes time if it is to be done properly and it will be important to introduce fresh thinking to stimulate entrepreneurs and family businesses to look more strategically at the long term prospects.

- There is a strong history of creative enterprise that has established a strong economic region but the 
pace of changes globally necessitate closer attention given the structure of the regional economy which relies on SMEs and the risks surrounding no clear exit or succession planning for future generations.

\section{P.3. Design rules according to the "think small first" principle}

- Given the predominance of micro and small businesses in the region, this is a key consideration for Lombardy. Procurement and licensing institutions in Lombardy region, including the local authorities, do recognise the importance of this and there are active initiatives to promote the principle including PR and instruments that encourage SMEs to work together in accessing more opportunities to win business. However the strength of partnerships to endure beyond the period of the instrument assistance or single contract opportunities remains a challenge that requires consistent encouragement to enable small businesses to gain full access to the opportunities available.

\section{P.4. Make public administration responsive to SMEs}

- A "Mr SME" role has been created, as has a SBALombardiaLab initiative. However, more could be done to target SME policy, such as a through a dedicated competitiveness and innovation strategy.

- There is progress with a number of pro-active measures in Lombardy to improve public administration recognition and responsiveness to SMEs. Public administration must encourage SMEs to become more demanding customers and seek more sophisticated support services to assist SME growth and sustained regional prosperity.

\section{P.5. Adapt public policy tools to SME needs}

- Various policy tools which are targeted at the SME sector. However, a key weakness is the lack of effective monitoring (to some extent) and evaluation (to a large extent).Without effective M\&E it is not possible to adapt policy tools to SME needs.

- Specific agencies and initiatives in Lombardy are moving in this direction and the SBALombardiaLAB initiative draws SMEs into the forum to raise awareness of how public policy tools are adapting to meet their needs. This can develop momentum and spark further changes that assist SMEs and the effectiveness of public policy tools.

P.6. Facilitate SMEs' access to finance and develop appropriate legal and business environment

- In order to facilitate the access to finance for SMEs and in particular to support them in the different stages of their lifecycle there the need of widening and diversifying the range of financial services (including risk capital, business angels, mezzanine finance etc.).

- Regional mutual guarantee schemes (Confidi) must improve their performances and reorganisation aimed at gaining greater efficiency is on-going but it is also important to ensure the territorial proximity of these schemes to target firms easing their accessibility for smaller businesses.

- The involvement of private sector in financing innovative businesses is a relevant option to be pursued in order to complement the public funding, therefore there is room for experimenting new forms of cooperation between public and private investors.

- There is a very strong regional focus on "internationalisation". However, there does not seem to be a deep understanding of what this really means or what it entails on the part of both policy makers and entrepreneurs, beyond the issue of "export".

- Many SMEs are not in a position to reach these opportunities. Specific instruments including ERGON project have worked to encourage SMEs to come but these are small in number at present. Further strategic prioritisation in key sectors of strength and greatest potential growth could enable SMEs to access more opportunities in the single market. 


\section{P8. Promote the upgrading of skills and all forms of innovation}

- The general skills environment, including vocational educational one, is in the process of being reformed. Much needs to be done to evaluate and further develop it, for example the Poli Formativi and the Dote Formazione systems. SMEs must be encouraged to make full use of all the opportunities available to raise their human capital, so as to enhance management, competitiveness and innovation levels.

\section{P9. Enable SMEs to turn environmental changes into opportunities}

- Initiatives such as SBALombardiaLAB have been working to raise awareness and provide channels to access information and assistance. Other institutions in the region must continue to develop their approach to engage SMEs in specific sectors such as energy, waste treatment and environmental services where major contracts can be won by SMEs.

- The need for achieving standards and accessing new business opportunities remains underappreciated with a short term perspective that such requirements represent an additional cost burden rather than a basis for developing new business. There is a need to change this perception by facilitating SME engagement and going beyond the provision of information to broker real projects that can become demonstrators for SMEs. In this way, interventions can be more productive and stimulate long term change from within SMEs.

P10. Encourage and support SMEs to benefit from the growth markets

- Competitiveness is a global concept which is creating opportunities in new emerging markets and many local SMEs could access new sources of revenue if the appropriate encouragement is maintained. Numerous initiatives have taken delegations of SMEs to visit potential buyers in other countries including missions to Russia and China and this should be expanded to promote internationalisation.

- Policy initiatives to support strategic sectors such as aerospace, ICT, biotech, design, renewable energies, new materials, green construction, etc. are planned.

- The BRICS countries are the source of future growth in GDP and export markets yet few SMEs explore or export to these territories. The dependence on low growth traditional markets will limit growth and it is essential that networking initiatives promote more internationalisation as part of holistic policy strategies on competitiveness, innovation and growth. Lombardy has number of fundamental strengths and a range of initiatives underway through partners and the SBALombardiaLAB in particular. These initiatives recognise that globalisation and the increased intensity of competitive change pressures have made innovation and more dynamic levels of inter-firm co-operation essential. However much more could be done to develop knowledge networks and encourage more innovation by SMEs and partners. 


\section{REFERENCES}

AECM (2009), "Fighting the Financial Crisis: Measures undertaken by AECM's Member organisations" available at http://www.aecm.be/servlet/Repository/fighting-the-financialcrisis.pdf?IDR=109

Directory of AIRI Associates (X Edition - 2009), AIRI, (Italian Association for Industrial Research).

Amin, A. \& Thrift, N. (2009), "Neo-Marshallian nodes in global networks", International Journal of Urban and Regional Research.

Amin, A. \& Thrift, N. (1994), "Holding Down the Global", in Globalisation, Institutions, and Regional Development in Europe, Eds. A. Amin \& N. Thrift, Oxford University Press, Oxford.

Becker, Gary S. (1964), Human Capital, 1st ed., New York: Columbia University Press for the National Bureau of Economic Research.

Cefis E. and Marsili O. (2005), "A matter of life and death: innovation and firm survival", Industrial and Corporate Change 14(6).

Consorzio Lavoro e Ambiente (2019), Report on Training and Support Structures for Young SMEs in Italy.

Cosh, A., Fu, X. and Hughes, A. (2005) "How much does informality in management matter for SME innovation?", Award winning paper, 2005 'European Best Paper Award'.

De Meza D. and Webb D.C. (1987), “Too Much Investment: A Problem of Asymmetric Information”, Quarterly Journal of Economics, 102, 2, pp. 281-292.

De Vincentiis P. (ed.) (2008), The Guarantee Systems and the SMEs Access to Credit, Bancaria Editrice, Roma.

De Vincentiis P. and Nicolai M. (eds.) (2012), I Confidi di nuova generazione. Gli impatti della crisi e delle nuove regole, Bancaria Editrice, Roma.

Destefanis, S. (2012), "Skills for Competitiveness: Country Report for Italy", OECD Local Economic and Employment Development (LEED) Working Papers, No. 2012/04, OECD Publishing.

Di Maggio, M. and Bandera, S. (2007), "Poli formativi lombardi: un primo bilancio a un anno dall'avvio", in Rassegna Autonomia Scolastica (pp. 23-28), IReR-Istituto Regionale di Ricerca della Lombardia.

EC (2003), Green Paper on “Entrepreneurship in Europe”, COM 92003, Brussels.

EC (2008), Entrepreneurial Diversity in a Unified Europe: Ethnic Minority Entrepreneurship/ Migrant Entrepreneurship, Brussels.

EC (2010), Europe 2020, Brussels. 
EC (2011), Review of the implementation of the SBA (February 2011), Brussels.

EC (2011), Report from the Commission to the Council and the European Parliament, Minimising regulatory burden for SMEs Adapting EU regulation to the needs of micro-enterprises, European Commission, Brussels.

EC (2011), "SBA Fact Sheet 2010/11" available at http://ec.europa.eu/enterprise/policies/sme/factsfigures-analysis/performance-review/files/countries-sheets/2010-2011/italy_en.pdf

EC (2008), Regional Dimensions of Innovation, Brussels.

Foundation Aristide Merloni (2009), Structure and Change in the Mache Region Production System.

Fung V.K., Fung W.K. and Wind J.R. (2007), Competing in a Flat World: Building Enterprises for a Borderless World, Wharton School Publishing.

GEM (2009), Global Entrepreneurship Monitor - Italy: 2008 Executive Report, EntER, Bocconi University and GEM consortium.

Hoffman, K., Parejo, M., Bessant, J. and Perren, L. (1998), "Small firms, R\&D, Technology and Innovation in the UK: A Literature Review", Technovation 18(1).

IReR (2010), “The region of Lombardy, Italy: Self- Evaluation Report”, OECD Reviews of Higher Education in Regional and City Development, IMHE, http://www.oecd.org/edu/imhe/regionaldevelopment

Istat, ASIA (2010), Struttura e dimensione delle unità locali delle imprese.

Keeble, D., Lawson, C., Smith H. L., Moore, B. and Wilkinson, F. (1998), "Internationalisation Process, Networking and Local Embeddedness", Small Business Economics, 11.

MacLeod, 1997 'Institutional thickness' and governance in Lowland Scotland. Area 29.

Marchese, M. and J. Potter (2011), "Entrepreneurship, SMEs and Local Development in Andalusia, Spain”, OECD Local Economic and Employment Development (LEED) Working Papers, No. 2011/03, OECD Publishing. OECD, 2011b.

McQuade T.J. and Butos W.N. (2009), “The Adaptive Systems Theory of Social Orders”, Studies in Emergent Order Vol 2 (2009).

Mistrulli, P. and Vacca, V. (2011), "Mutual guarantee institutions and small business credit during the crisis", Occasional paper 105, Bank of Italy.

Mussati, G. (2008), Overview of Family Business Relevant Issues: country fiche Italy, Brussels.

OECD (1998), The OECD Jobs Strategy Fostering Entrepreneurship, OECD Publishing.

OECD (2006), The SME Financing Gap. Theory and Evidence. Volume I, OECD Publishing.

OECD (2009), "Clusters, Innovation and Entrepreneurship", Local Economic and Employment Development (LEED), OECD Publishing. 
OECD (2010), Assessment of Government Support Programmes for SMEs' and Entrepreneurs' Access to Finance in the Global Crisis, OECD Publishing.

OECD (2011), Higher Education in Regional and City Development: Lombardy, Italy 2011, OECD Publishing.

OECD (2011a), Regional Outlook: Building Resilient Regions for Stronger Economies, OECD Publishing.

OECD (2012), Better Skills, Better Jobs, Better Lives: A Strategic Approach to Skills Policies, OECD Publishing.

OECD (2012), Financing SMEs and Entrepreneurs 2012: An OECD Scoreboard, OECD Publishing.

Potter, J., A. Proto and M. Marchese (2010), "Entrepreneurship, SMEs and Local Development in the Marche Region, Italy", OECD Local Economic and Employment Development (LEED) Working Papers, No. 2010/12, OECD Publishing.

Sevilir, M. (2006) "Human Capital investment, Entrepreneurship and New Firm Creation, Regional Comparative Advantage and Knowledge-Based Entrepreneurship", RICAFE2 First Conference, 5-6 October 2006, LSE.

Stiglitz J. and Weiss A. (1981), "Credit Rationing in Markets with Imperfect Information", The American Economic Review, Volume 71, Issue 3, pp. 393-410.

Zukerman E.W. (2003), “On Networks and Markets”, Journal of Economic Literature Vol XLI, 2003. 


\title{
ANNEX I:
}

\author{
Learning Models
}

\section{Business environment and SME networks}

\section{1) The Swedish Agency for Economic and Regional Growth, Sweden}

\section{a) Description of the approach}

The Swedish Agency for Economic and Regional Growth has an assignment from the Government to support initiatives that help people to realise their business concepts. The agency covers the 21 counties and 290 municipalities within Sweden. The aim is to get business concepts put into practice, which may lead both to new companies and to the development of existing companies. Actions are based on an innovation and sustainability perspective intended to create opportunities for a diverse range of entrepreneurs with different experience and a diverse range of different business forms.

The Swedish Agency for Economic and Regional Growth works on co-financing different types of projects to provide advice prior to the start or development of a company. Other action focuses on influencing attitudes to make more people interested in enterprise. They also work on promoting business development in small and medium-sized enterprises, where special attention is focused on areas like product development, capital provision, knowledge development and preparations for internationalisation.

The agency endeavours to reduce barriers to start up and business growth by reducing regulatory burdens, promoting business reforms and providing access to methods to assist business growth, including training assistance. The agency collaborates with several other government agencies, including the Swedish Tax Agency and the Swedish Companies Registration Office, to facilitate business start-up and growth.

One specific initiative has been to launch an entrepreneur website www.verksamt.se in order to provide concerted service and information from the agencies affected by different phases of enterprise: considering, starting, running, developing and closing down a business. This includes assistance to finance growth, manage the growth process and providing access to venture capital. As part of managing growth, cooperation and networking with other businesses in the region and beyond is encouraged. They also promote access to expert help and nosiness mentoring through these regional networks.

\section{b) Rationale for policy intervention}

The approach has assisted to maintain Swedish high performance in entrepreneurship and specific business growth successes. The agencies work together to provide a range of services and access to advice essential to SME networking for sustainability and growth. 
The generic approach can be focused for each client in line with the business model needs and growth potential. This creates opportunity for specific assistance packages that assist SMEs to plan for the future and access the best form of networks for their stage of development and realisation of future aspirations. This can include:

- How to keep track of the dynamic development of markets, new technology and meet competitive challenges with appropriate expertise and support.

- Looking ahead at customer and market developments and expectations for a new, modified or extended product or service offering. This can assist business to identify promising new market segments for future targeting and adjustment of strategy and investment plans.

- Scope for acquisition of tools, technology, skills or other resources including investment to develop new products or processes and what needs to be done in order to access these resources.

- Understanding risk and pay-off periods to test new developments or technology.

- Access to CPD for staff competence, training, knowledge and skills updates.

The approach is successful in assessing future growth possibilities and the impact on a business model as growth occurs. This assist to identify the future needs for further business adjustment and change.

\section{c) Strengths and weaknesses}

There are a number of strengths from this approach that work well together including:

- The one door approach is important for business which can then identify specific follow-up sources and resources suitable for specific business needs.

- Access to a range of networks, experts and investment resources appropriate for business development.

- Provision of an integrated route to support in a timely manner taking the business leader through a structured process to assist understanding of business development, growth challenges, risk and returns.

- Access to knowledge on markets and business models.

- Assistance in a linear logic progression as businesses growth and expansion occurs.

Some of the weaknesses could be considered:

- The approach is generic and requires assistance focus and navigate through the stages;

- As a consequence, the process requires commitment and investment of time to develop a bespoke solution;

- Information requirements for data and knowledge to be shared can discourage some SMEs reluctant to do this; 
- Speed of response in key areas of urgency can be slower than private assistance and this is often vital for many companies in highly competitive, fast changing markets or those facing sudden crisis conditions.

\section{e) Considerations for successful adoption in the Lombardy region}

The regional perspective is a good level to encourage networking and nurturing a stronger, more resilient business environment. The specific context in Lombardy and the horizontal integration of different agencies/stakeholders would require to be reviewed when considering how to implement a similar approach as in Sweden. Cultural considerations will be important and finding the balance that suits business expectations as well as encouraging changes for improved and more transparent practices amongst SMEs in Lombardy.

The model in Sweden is based on good practice. From a national competitiveness perspective, it being developed practically at local level so there is evidence that it can transfer to strengthen the regional business environment and provide a stimulus to SME networking regionally and internationally.

\section{f) Information}

The Swedish Agency for Economic and Regional Growth (Tillväxtverket)

Web: www.tillvaxtverket.se

\section{2) UK Business Innovation and Skills (BIS), United Kingdom}

\section{a) Description of the approach}

The UK Government's stated economic policy objective is to achieve strong, sustainable and balanced growth that is more evenly shared across the country and between industries. In 2009 the Government commissioned a review of regional growth and assistance which was published in 2010 as "The Growth Review". The Growth Review invited business to take part in a fundamental assessment of what each part of Government could do to create the best conditions for private sector growth. It has become a rolling programme in England and Wales designed to last five years.

The findings of the Review led to a Plan for Growth which was endorsed and included in the Government budget of 2011. The Plan for Growth is based on four overarching ambitions for the British economy:

- Create the most competitive tax system in the G20.

- Make the UK the best place in Europe to start, finance and grow a business.

- Encourage investment and exports as a route to a more balanced economy.

- Create a more educated workforce that is the most flexible in Europe. 
Macroeconomic conditions are seen as vital to reduce uncertainty and provide a stronger information set on which firms and other economic actors can base pricing, production and resource allocation decisions. Enterprise and SMEs lie at the heart of the policy priorities.

\section{b) Rationale for policy intervention}

The department for Business Innovation and Skills (BIS) in the UK is the lead organisation for implementing the UK Government's policies for growth. The remit is based on the rationale that there is a clear and active role for Government to create the conditions for the private sector to grow and remove unnecessary barriers to growth. The focus is on positive growth by combining the responsibilities for skills, innovation and business growth issues in an integrated way to create the right conditions for businesses to succeed, removing barriers that are preventing them from performing to their full potential.

The underlying rationale recognises the market failure and imperfections that inhibit efficient operation of markets, including the asymmetry of information, externalities (including environmental externalities), and a tendency to move towards non-competitive structures that can all become barriers to SME growth.

The government is seen as having a key role in setting market frameworks to promote fair competition, markets that are open to trade, and measures to tackle regulatory burdens on businesses. Regulation is seen as a last resort with culture change being the preferred way forward.

\section{c) Relevant to Lombardy}

The UK government has stressed the importance of locally led approaches to economic development set within an over-arching national framework of policy. This has been set out in a government White Paper that created Local Enterprise Companies within natural economic geographies, replacing the previous Regional Development Agencies (RDAs).

The UK BIS approach shows the importance of local areas (through local economic partnerships) in delivering a renewed focus on opening markets up to drive growth through both the entry and expansion of more efficient firms, and incentives to improve productivity growth in existing firms. This approach draws on economic theory and international evidence to identify four pillars, each representing a policy area which is crucial to driving growth. These are all relevant to Lombardy:

Pillar 1: Providing the stability business needs.

Pillar 2: Making markets more dynamic.

Pillar 3: Effective government that supports investment and growth.

Pillar 4: Supporting individuals to fulfil their potential.

Enterprise creation and performance drive economic growth and the UK policies of BIS show evidence based learning that lead to four main priorities in the UK also relevant to Lombardy:

- A more targeted and efficient model of business support delivery, including a greater focus on management and strategic capacity.

- Increasing the strength of enterprise culture. 
- Ensuring that businesses with export potential can access overseas opportunities and optimise that potential.

- Improving access to finance for businesses with growth potential

Certain areas are of special interest to Lombardy challenges, including the growth SMEs and high growth SMEs in particular.

\section{Coaching for high growth SMEs}

The UK has a new Business Coaching for Growth programme (BCG). This aims to accelerate developments in the most promising high growth SME's and boost economic growth. It is designed to achieve maximum economic advantage by increasing the number of businesses that achieve genuine high growth; the businesses that contribute the most too economic and employment growth.

BCG is an ambitious new programme, coordinated nationally but delivered at a local level, which provides high quality coaching support for up to 10000 SMEs a year with high growth potential. The programme provides coaches to work face to face with senior management teams, to help them develop and implement their strategies and overcome the challenges that businesses face on a range of issues such as sales, raising finance or exploiting innovation.

Along with the high quality coaching, the programme gives bespoke solutions to growth SME challenges, promoting networking and makes specific connections for high growth potential businesses. This includes making links to:

- External finance - Business Angel Networks, Venture Capitalists.

- Business Support Services - Trade (UK Trade and Investment), Innovation (Technology Strategy Board), Intellectual Property (Intellectual Property Office), Manufacturing (Manufacturing Advisory Service) as well as private sector delivered solutions.

- Access to Premises - science parks, universities, business incubators.

BCG will target established businesses and start ups with the potential to achieve fast or high growth rates as defined by set criteria:

- SMEs with 10 or more employees with the potential to increase turnover or employment by an annual average rate of $20 \%$ over three years.

- SMEs with fewer than 10 employees that over three years have the potential to increase employment by at least 7 employees or annual turnover by $£ 0.75 \mathrm{~m}$.

- Start-ups with potential to achieve turnover of $£ 1 \mathrm{~m}$ within three years of starting trading, or to have at least 10 employees within three years.

The programme is being delivered by a bespoke Coaching for Growth Consortium comprising private sector advisors and key delivery partners with connections to local support providers across all issues and policy areas relevant to high growth SMEs. 
These initiatives in the UK Are designed to create a more balanced economy where private sector led SME growth is central and barriers to growth are lowered. The role of new Local Enterprise Partnerships is central to this transition and the focus on delivery.

\section{Local Enterprise Partnerships (LEPs)}

In England, the government abolished regional development agencies and set up local enterprise partnerships, new agencies led by local authorities and businesses covering "natural economic areas". They aim to provide vision, knowledge and strategic leadership to drive sustainable private sector growth and job creation in each local area.

Each local enterprise partnership identifies their local priorities. This includes investment support for local business needs, and working with Government to support enterprise, innovation, promoting exporting and inward investment. The aim is to have business leadership pushing on issues and policies critical to growth within real economic geographies. The objective is to have a stronger environment for business growth, SME development and sustainability.

A 'toolbox' was developed to help LEPs to pursue their priorities. The toolbox provides information on economic development activity across government departments and potential routes for assistance and cooperation. Examples of new ideas and collaborative working will be added over time.

\section{d) Reasons for the success or failure of the approach}

The approach is just being embedded in the UK which is still making the transition process following the changes introduced after the government election in 2010. However the measures introduced have streamlined the processes for SMEs and the initiatives are led much more by local private sector efforts rather than regional governmental agencies. Networking has been strengthened and access to expertise to assist SMEs has been made more readily available through initiatives such as mentoring which can be tailored to the needs of the business and the development of relationships at various levels. For growth SMEs this is especially helpful as it can open more doors more quickly to reach potential investors and to learn from the practical experience of others.

The approach has encouraged local leadership and networks to take more prominent roles in working to develop the local economy (regions broadly but defined by more natural economic relationships rather than administrative boundaries). For Lombardy, and Italy generally, with so many municipality and district authorities and layers of economic agency actors, this streamlining has particular relevance.

\section{e) The obstacles faced in implementation and the quality of the response taken}

The approach is fostering new network relationships led by the private sector which is seen as the source of growth in the economy. In many areas, the public sector agencies have been the traditional lead players in setting regional economic strategy and providing services for SMEs. The transition has caused difficulties and many of the initiatives are seen as re-inventions rather than novel creations.

At a time of economic difficulties and weak levels of economic growth, many SMEs continue to struggle with the basics of survival rather than the sophistications of growth. Demand is high for basic assistance to SMEs but resources are increasingly focused on high growth SMEs (which has been interpreted by some observers as akin to picking winners) and a requirement for significant innovation 
and internationalisation commitments. This has motivated many SMEs but also many remain sceptical especially as budgets and specialist support staff numbers have often been reduced.

Many SMEs have been slow to respond to the new relationships and to understand the new organisational structures with amended routes to assistance. The environment is much more competitive in every sense and it is not always clear that the best cases for growth receive the priority assistance as evaluation evidence remains elusive.

\section{f) Considerations for successful adoption in the Lombardy region}

Many of the new initiatives in the UK have relevance for Lombardy. This includes reducing the bureaucracy and barriers to growth; clearing the structures to enable businesses to better understand how to reach support for growth; opening up new networking opportunities; promoting exporting to growing markets including the BRICS; new relationships with other players including public sector procurement opportunities and higher education institutes.

In considering how to introduce specific versions of this in Lombardy it will be important to have a deeper review of the evidence of what works well and what is not working in Lombardy. Evaluation evidence is vital and a full review of the network support landscape, including the role of second tier organisations and whether many could be re-grouped at a higher level for greater economic impact. In this way real positive change for growth could be introduced alongside the legislative framework, including the SBA.

\section{Entrepreneurship and SME Workforce Skills}

\section{3) Q.NET, Germany}

\section{a) Description of the approach}

Germany has a relatively large immigrant population (approx. 20\%) and the unemployment rate among immigrants is twice as high as among native Germans. The outlook is not much better for selfemployed immigrants and the business failure rate among ethnic minority entrepreneurs is also high. In part this is attributable to the migrants' low level of participation in the education system reinforced by a high drop-out rate among immigrants at secondary schools and low participation in Germany's dual system of vocational training. The mainstream employment and qualification schemes often fail to reach ethnic minorities and there is a lack of business support services targeting this group. Q.net seeks to improve immigrants' chances on the labour market, including self-employment. It focuses on immigrants' participation in adult education programmes and aims to improve existing training programmes so as to increase immigrants' participation thus stimulating immigrants' job security and to increase the number of successful business start-ups. Q.net is run by the North German Network for the Professional Integration of Immigrants (NOBI), which aims to establish an information and counselling network for a better professional qualification and integration of ethnic minorities. It targets adult immigrants, governmental and non-governmental institutions, as well as organisations specialised in the field of employment, business start-ups and adult education. Together with five other development partners a nationwide network for information and counselling called "Integration through Qualification" (IQ) has been established, which was set-up by the Ministry of Labour and Social Affairs and the Federal Employment Agency (see EC, 2008). 


\section{b) Results of the approach}

The programme has had a positive impact in Bremen: Q.net's overall result led to improved access to information, as well as a higher participation rate of immigrants in training programmes. The very design of the training system is specifically customised for ethnic minority entrepreneurs; the various studies and information leaflets (e.g. needs assessments, trilingual guide for business start-ups, case studies (Qualitreff), etc. During the first implementation period (2005 to 2007) 436 immigrants participated in one or more training and counselling sessions, 71 of whom already had a business. The other 365 included 148 starting entrepreneurs and 217 immigrants that participated in the training to increase their chances to preserve their current job or to find a new one. All 148 start-ups were still in operation at project end. This was all based on a budget of Euro 700000.

\section{c) Strengths and weaknesses}

- Through stakeholder contacts (e.g. immigrant organisations) Q.net gains access to its target group, analyses their needs and designs customised training programmes. This is what helps immigrant business start-ups to succeed and improve immigrants' chances on the labour market.

- Another strength is that it addresses the interests of stakeholders at different levels in society: immigrants, training centres, institutions and policy makers. Q.net raises immigrants' awareness for training, improves the quality of training services, creates networks between immigrants and institutions, and provides valuable inputs to policymakers.

- The programme emphasises networking at three key levels: i) between existing and potential ethnic minority entrepreneurs; ii) between ethnic minority entrepreneurs and consulting agencies and iii) between ethnic minorities, media representatives and policy makers in order to raise awareness for the needs of immigrants.

- The sustainability of the programme's outcomes depends on the cooperation between the involved strategic partners; this is a potential weakness unless all are committed to its success.

- Immigrants are frequently unaware of their needs and the existence of training and support services. Unless policy initiatives place significant effort on promotion and awarenessraising for the target group, the impact will be affected.

- In order to avoid having a supply-driven approach, a needs assessment is a key preliminary step in designing a policy for immigrants. This enables effective targeting, development of tailor-made services and raises immigrants' awareness of the existence of such services.

- There is a need to counteract perceptions of the role of immigrants in society and economy. It is, therefore, important to make good use of the media to highlight success stories, thus counteracting stereotypes.

\section{d) Considerations for successful adoption in the Lombardy region}

The analysis has shown that immigrants make-up a large and growing element of the labour market in the Lombardy region. Furthermore, discussions during the fieldwork underline the point that this group already contributes to the economy in terms of self-employment and new enterprise creation, especially in view of the ageing population structure a weakness relates to the issue of fully 
utilising the labour force through labour market integration. Access to employment requires the acquisition of language and human capital, the recognition of the migrant qualifications, as well as access education, training, information and connected support services. Ultimately access to employment opens the door to unemployment benefits or other contribution-based benefits (i.e. childraising allowances, pension rights, etc.). Whilst recognising that policy emphasis of the Lombardy region, it is important to explore all options for increasing access to employment, self-employment and new enterprise creation through initiatives such as the one presented in this learning model.

\section{Information}

DP-NOBI: http://www.ep-nobi.de

Integration through qualification: http://www.intqua.de

AWO-Bremen: http://www.awo-bremen.de/zugewanderte.php?menu=3\#qnet

\section{DP NOBI}

Lange Reihe 81

20099 Hamburg

Tel.: +494028084625

Web: www.ep-nobi.de

\section{4) Centre for Amsterdam Schools for Entrepreneurship (CASE), The Netherlands}

\section{a) Description of the approach}

CASE is a collaboration project between various further education institutions in Amsterdam (University of Amsterdam, VU University Amsterdam, the Hogeschool van Amsterdam - University of Applied Science and the University of Applied Sciences Amsterdam), as well the municipality of Amsterdam, the Dutch Chamber of Commerce, the Amsterdam Knowledge Network Foundation (Kenniskring), businesses, entrepreneurs and student organisations, to develop entrepreneurship education with the aim of improving entrepreneurial skills among all students in Amsterdam. The aim of CASE is counteract the fact that more than $90 \%$ of the students in Dutch education institutions do not come into contact with entrepreneurship or entrepreneurial behaviour during their time at university. A sound familiarisation with entrepreneurship is lacking for students, with the result that they are insufficiently informed about entrepreneurship as a study and career option. It is also designed to overcome the fact that too little attention is currently paid during studies to entrepreneurial skills, which are necessary for employees. CASE seeks to increase accessibility and multidisciplinary entrepreneurship education for students through three programmes:

- Studying Entrepreneurship: CASE makes entrepreneurship studies possible for all students in Amsterdam in that students from all disciplines can take part in education that inspires ambitious and internationally-oriented entrepreneurship, thus ensuring that entrepreneurship and entrepreneurial behaviour are experienced by students, and their entrepreneurial skills are thereby improved through the following activities:

- Entrepreneurship courses: practical training modules to develop entrepreneurial behaviour and relevant skills (e.g. new venture creation, making businesses ready for takeover, consultancy in young SMEs, commercialisation of inventions, research and advice into and about a sector of industry and helping less-privileged young people in setting up a business plan). 
○ Entrepreneurship minors: in various courses institutions, such as VU University Amsterdam and University of Amsterdam.

o "Entrepreneurship" Honours Programme: which started in 2010 and offers students the chance to spend more time on this topic and to broaden their horizons.

○ Joint Entrepreneurship MSc: three Entrepreneurship Master degrees have been developed and the ambition is to have a common M.Sc. in Entrepreneurship in Amsterdam.

o Policy-relevant study into the determinants of successful entrepreneurship.

- Inspiration/awareness: so that awareness among students is increased about the importance of entrepreneurship and entrepreneurial skills, including:

- Global Entrepreneurship Week: which stimulates young people to be economically independent by investing in educational projects and entrepreneurship. More than 150 activities took place in The Netherlands during 2009, drawing attention to entrepreneurs.

- Student Entrepreneurs 020: In 2009, an association for entrepreneurial students was founded (www.studentondernemers020.nl), which organises monthly entrepreneurs' café meetings, and which is visited by about a hundred students.

- Starting and growing: CASE is also active in the field of starting/growing businesses:

- Breeding ground for entrepreneurial education and student start-ups: for 200 minor students per term in Vijzelstraat; for 17 start-ups in Wibautstraat; and for 3 start-ups in the Matrix Innovation Centre.

- Entrepreneur Summer School: over the course of a week, students develop ideas into business plans. During the Summer School, students learn from lecturers and entrepreneurs about finance, marketing, sustainability, sales, strategy and networks.

- StartersCASE: this aims to create a professional and realistic entrepreneurial environment for the students; for example, calculation of VAT and invoicing with the foundation's Company Registry number, banking through a special bank account, etc.

- Kennispoort Amsterdam (Amsterdam Knowledge Gateway): institutions work to build a bridge between SMEs and education. Via Kennispoort, entrepreneurs come into contact with students, who address business issues to real entrepreneurs within the framework of a practical course, project, etc.

○ (Alumni) entrepreneurs: is a community of 500 alumni entrepreneurs, a number of whom are involved as guest lecturers and coaches of the student entrepreneurs. Profile portraits of entrepreneurs are placed on the website and a portal with video portraits of student entrepreneurs has been created (www.ace-ondernemersvuur.tv). 


\section{b) Results of the approach}

Over the course of a few years, CASE has had a positive influence on the economy. A sub-set of the achievements of CASE are highlighted below:

- 30 student companies have been set up within StartersCASE, 100 new businesses have emerged from the minors, 15 from the Summer School and there have been 15 start-ups in the entrepreneurs' breeding grounds.

- The project has improved the collaboration between the stakeholders and made it more structured by means of networks, outreach, etc.

- The companies and start-ups are still in the early phase of growth and on average three to four entrepreneurs take part in a start-up.

- Whereas in 2004 , only $7 \%$ of the students considered undertaking a business as a career option, this percentage has now increased to more than $20 \%$.

In 2010 the CASE was structured into a permanent organisation in order to make it sustainable.

\section{c) Strengths and Weaknesses}

The key strength of the CASE activities lies in the strong emphasis on practical, businessoriented education and training, which complements the imparted theoretical knowledge. Furthermore, the programme does not restrict itself to any particular course or faculty - CASE support is available to all students, regardless of educational and other background. Moreover, CASE presents an example of a Public-Private Network, which seeks not only to stimulate start-ups, but also to develop skills which are in demand in the wider labour market. Furthermore, the CASE initiative connects well with national and EU programmes, which increases the chances of obtaining funding and expanding the activities, thus reaching a wider range of students.

Inevitably, such a partnership arrangement involving various actors and stakeholders in both the public and private spheres, means that there are many different and sometimes competing interests among partners which need to be handled in order to generate interest, maintain commitment and ensure sustainability of activities. Connected with this is the critical issue of finance, since CASE involves activities over and above the usual strictly academic ones. As a result it is dependent on continuing financial commitment by the universities, local government, donors including EU, etc. Budgetary changes at central / local government level can rapidly affect such initiatives.

\section{d) Considerations for successful adoption in the Lombardy region}

Graduates make a direct and material contribution to entrepreneurship. The Lombardy region needs a new generation of entrepreneurs and entrepreneurial employees to contribute to growth, innovation and profitability of the regional economy. The region is seeking to increase its share of fast-growing companies and, in doing so, it is critical that a higher share of graduates engage in establishing enterprises, that higher education students benefit from a greater entrepreneurial emphasis and support, thus ensuring that education contributes in general to the development of entrepreneurial behaviour and associated competencies that can be carried forward into existing and new companies.

The higher education system in Lombardy could benefit from the development of new educational forms which pay sufficient attention to entrepreneurial mind-sets and skills. Students, even 
whilst at university, have the potential to establish new firms as a component of their training. In addition, initiatives such as CASE engage existing entrepreneurs in the training, for example as clients, teachers or coaches of the students. By involving existing networks of governments, businesses and entrepreneurs in the development and implementation of such projects at the regional level, better linkages and deeper networks of relationships evolve. The resulting cooperation between the higher education institutions, students and indeed enterprises would be of importance to sustaining and enhancing the regional economy.

\section{Information}

Amsterdam Center for Entrepreneurship

Erik Boer, Director

Roetersstraat 11, 1018 WB Amsterdam, The Netherlands

Tel.: +31 (020) 5256303

E-mail: F.Boer@uva.nl

Web: www.ace-amsterdam.org

\section{New Enterprise Creation}

\section{5) Austrian Transfer Brokerage and Guide, Austria}

\section{a) Description of the approach}

The population and business demographics of Austria are such that each year, some 6000 entrepreneurs seek to transfer their enterprises. In many cases, it makes more sense to take over an existing business, rather than to establish a new one. However, this process is neither straightforward; nor inevitable, but requires planning, preparation, advice, identification of willing sellers and buyers, etc. The economic Chamber of Austria has, therefore, focused on providing services, including at the regional level focusing on three key issues:

- A guide for firm succession;

- A firm transfer database / brokerage;

- Supporting services.

\section{b) Results of the approach}

By facilitating the transfer process, the Transfer Stock Exchange / Brokerage and Guide contribute greatly to preserving and strengthening the Austrian economy. The Guide to Succession is a key foundation which provides information on all aspects of business succession, such as company valuation, contractual issues, inheritance tax matters, access to finance, and other fundamental concerns for potential buyers and sellers. Other publications, information and advice are available at the regional level. The on-line guide and successor brokerage is a well-used service that meets a key information gap: it provides information and contact details of potential successor firms and potential buyers (i.e. both demand and supply). To results of the online tool are impressive: out of the estimated 6000 firms that could potentially benefit from this service, there were 2410 offers (about a third of the estimated demand for this service) and 421 requests for matches so far. Data on how many of these were successfully transferred as a result of the service offered are not available. 


\section{c) Strengths and Weaknesses}

The key strength of the system is that it provides information and support in relation to a topic which is sensitive and complex. Moreover, by bringing together demand and supply, it greatly increases the chances of success for both the seller and the buyer. The key weakness is that the guide and database are not sufficient. They are an important starting point, however, the potential buyers and sellers need to be brought together and advice and support must be offered to increase the chances of success. The Austrians increase the success of the initiative by having nominated contact persons in the regions.

\section{d) Considerations for successful adoption in the Lombardy region}

The ageing population structure of the region, combined with the decreasing dynamism of the company demography makes the issue of critical importance in the Lombardy region. As indicated in the recommendations, this challenge represents a threat, as well as an opportunity for the regional economy. It offers an opportunity to review the current firm strategies, products and services and creates the scope to re-invigorate and re-orientate firms for long-term sustainability and profitability. However, it is clear that the founders-owners face complex options about whether to close the firm; sell it; transfer to family member; transfer to others; attract domestic/international investors; establish joint ventures; etc. Through the development to a guide, database and support services, the region could improve the effectiveness of transmission from the first generation of entrepreneurs to the next one, whether to family members or others. The guide and database for the region could be supplemented with a well-resourced programme focusing on awareness raising, customised training, as well as targeted technical, legal support and financial support.

\section{Information}

$\underline{\text { www.gruenderservice.at }}$ www.nachfolgeboerse.at

Each region has its own contact details. For Vienna, these are as follows:

Start-up Service, Vienna

Stubenring 8-10

A-1010 Wien

Tel.: +43 1514 50-1050

Fax: +43 1514 50-1491

Web: www.gruenderservice.at/briefkastenwien

Transfer Brokerage, Vienna

Stubenring 8-10

A-1010 Wien

Tel.: +43 1514 50-1043

Fax: +43 1514 50-1491

E-mail: nachfolgeboerse@wkw.at

Web: wko.at/wien/nachfolgen 


\section{6) Barcelona Entrepreneurship Centre (Barcelona Activa), Spain}

\section{a) Description of the approach}

The "Barcelona Entrepreneurship Centre" (BEC) was created in 2004 to foster quality employment and economic activity in Barcelona, focusing on the creation of start-ups. In the time since, BEC has become the reference point for entrepreneurs in the city of Barcelona; it is basically a hub that aims to boost the levels of entrepreneurship in the city through the activities and resources provided by Barcelona Activa, the local economic development agency, which is responsible for economics, business and employment in the City of Barcelona. BEC offers a self-use space that helps transform business ideas into feasible business projects through a programme of daily training activities, access to on-line content, expert coaching and cooperation among entrepreneurs.

The BEC model is based on three pillars:

- Digital contents to support entrepreneurship: integrated into the web portal www.barcelonanetactiva.com:

○ Digital tools that interact with the entrepreneur such as: On Line Welcome Session (set of 8 introductory videos to learn the basics of entrepreneurship and get to know the available resources of support); On Line Business Plan (tool that assists entrepreneurs in the production of a business plan); Test Idea (guide to assess the business idea through a SWOT analysis; The Keys to Enterprise (tool for self-assessment, acquisition and integration of key entrepreneurial skills); and Ubica't (geo-referencing service with databases containing information of interest to entrepreneurs in the city of Barcelona.

- On line guides: information on legal issues, funding and business ideas generation.

- Relevant information of the entrepreneurship field, published daily by the web portal.

- Short-term training activities: group activities, updated according to the needs and priorities of the users, to acquire basic entrepreneurship knowledge and key entrepreneurial skills:

○ On a permanent basis: this includes Welcome Sessions (information on entrepreneurship and on BEC, its resources and services); The "Knowledge Pills" (series of 25 executive training sessions in technical skills required for entrepreneurship presented by experts; each "pill" lasts two hours).

○ On demand: this includes Knowledge Weeks for Entrepreneurs (thematic conferences with a focus on practical approach and open to the general public); Enterprising July (training sessions during the month); Mondays of the Self-employed (four hour training on tax obligations and procedures); Business Idea Generation Workshops (assessment of coherence of project ideas); and Tailor-made programmes addressing strategic economic sectors and specific target groups.

- One-to-one technical coaching: a personal service provided by a team of technical experts who address specific questions and issues, thus adding value to the potential and actual entrepreneurs' efforts. The sessions last about 30 minutes for the potential entrepreneurs have previously attended training activities, so that entrepreneurs can proceed with their business plan.

\section{b) Results of the approach}

Since 2004, BEC has had over 180000 clients, has coached over 12000 business projects and has contributed to the creation of over 6800 firms, which have generated over 12800 jobs. In 2011 alone, 
BEC had 36566 participants in the programmes to support entrepreneurship and 2453 business projects were coached. There was a very high average creation rate of new businesses (nearly $70 \%$ ), which translates into 1700 new companies. The information available indicates that $85 \%$ of the companies that were created in 2007 were still active three years after being established. Each company generates an average of 1.9 jobs and a total of 3200 jobs were created in 2010 . On an annual basis, companies raise an average of almost EUR 3000000 worth of funding. As for the profile of the entrepreneurs assisted by BEC, 50\% were previously unemployed and $49.5 \%$ are female entrepreneurs.

\section{c) Strengths and Weaknesses}

A key strength of the model it its holistic approach in that it basically generates a referral mechanism through other entities or services and collaborates with multiple agents and platforms. A further advantage is that BEC provide services through the entire entrepreneurial process and value chain: from the idea, through the start up to the global business, which is advantageous for potential entrepreneurs. The entrepreneurial spirit can be maximised because the generic BEC model has the capacity to be targeted at specific groups and/or sectors. Finally, the approach is flexible and thus responsive to the potential entrepreneurs' need in that clients are supported through a standard professional process, which still allows customisation to individual needs, for example though the coaching sessions. The fact that BED constantly measures its impact, assist the process of improving the service delivered.

A strength, and yet at the same time a notable weaknesses, is the heavy reliance on electronic content. The BEC approach is based on a combination of on-site and on-line support content and applications, which might pose a problem or restrict access to the service for people without (sufficient) ICT knowledge. To overcome this problem, BEC users have access to a programme (Cibernarium) for the acquisition of IT skills by for Internet beginners, as well as professionals and companies. The BEC model is deliberately pitched at addressing the needs of a large number of people, which may influence the degree of individual support throughout the enterprise generation process whole process. This is compensated for though tailor-made programmes designed to meet the needs of specific target groups and/or strategic sectors that may need alternative methodologies and more intense support.

\section{d) Considerations for successful adoption in the Lombardy region}

At a time of growing unemployment, especially youth unemployment, it is worth considering to establishing a one-stop-shop facility where potential entrepreneurs can obtain a joined-up, integrated service in relation to starting a business. One of the most notable weaknesses of the Lombardy region is that, despite having programmes and activities which touch upon the issue of entrepreneurship, these are highly fragmented in nature. This means that the region could benefit from the establishment of a single, easily identifiable place where all potential entrepreneurs can go to if they wish to consider establishing a business. Such a one-stop-shop dedicated to the issue of stimulating start-ups would provide all the necessary information, training, support and services as a package, including support with access to finance matters and hands-on coaching for potential entrepreneurs.

\section{Information}

Claudia Garcia / Elena Del Rey

International Cooperation Projects Officer

Barcelona Activa SPM SAU

C/Llacuna, 162-164, 08018 Barcelona

Tel.: +34934019636 
Web: www.barcelonactiva.cat

E-mail: claudia.garcia@barcelonactiva.cat / elena.delrey@barcelonactiva.cat

\section{Knowledge Networks and Innovation}

\section{7) UK Department for Business, Innovation and Skills (BIS), United Kingdom}

\section{a) Description of the approach}

Innovation and internationalisation are seen as central to improving economic growth. Economic policy priorities in UK regions recognise this. Government emphasis also recognises that within competitive markets, a sound intellectual property framework is essential to protect incentives for entrepreneurship and innovation in the UK economy.

The UK approach stresses that innovative firms should drive growth in the economy. The UK Government has an ambition to be the most technology-friendly government in the world. A Blueprint for Technology was created along with the Technology Strategy Board, the prime channel through which the Government incentivises business-led technology innovation. This organisation has a budget of over $£ 200$ million to establish a network of Technology and Innovation Centres to help commercialise new and emerging technologies; introducing a new Entrepreneur Visa; and launching a new 'peer to patent' system which draws on the expertise of people across the globe to help maintain patent quality.

\section{b) Rationale for the policy intervention}

The approach recognises that many of the benefits from innovation come not from new ideas, but from spreading the benefits of existing technologies. This spreading of new technologies is promoted through openness to trade, more competitive and efficient markets and a higher skills and productivity levels. There is a clear rationale for intervention to improve outcomes and address market failures such as information asymmetry and negative externalities. There is a renewed focus for business support so it is more responsive and better targeted.

\section{c) Relevance to the Lombardy region}

Lombardy faces challenges in developing more innovative firms and boosting innovation across the SME communities, industries and sectors. Many of the new initiatives in the UK are relevant in illustrating how to help businesses to grow through improved innovation and high performance networks. For example UK 'Growth Hubs' have been created to help businesses with higher growth potential to identify the barriers that are stopping this growth. The 'Hubs' will provide businesses with access to specialist coaching, mentoring, investment-readiness advice, and will point them in the direction of help on issues such as innovation and exporting. The UK has shown that a network of growth hubs will deliver a number of new benefits to SMEs:

- tailored specialist advice to improve the investment readiness of small companies, making them more aware of equity as a source of finance;

- developing their management teams and business models;

- strengthen networks and bring together investors and growth-potential small businesses; 
- link education and research institutes and small businesses and investors supporting new business innovation development, education and mentoring.

UK has also introduced measures to address the investor and equity gap faced by SMEs. The UK Innovation Investment Fund (UKIIF) was specifically created to address this financing need (up to $£ 10 \mathrm{~m}$ ), driving economic growth and creating jobs by investing in technology-based businesses with high growth potential. The UKIIF creates a fund that replicates what the best US funds already do: making investments at all stages, with the kind of scale that can build businesses with global reach. This Fund has now begun investing into high-tech, innovative UK businesses.

Alongside prioritising spending that promotes growth, the UK Government has committed to driving up the productivity of public spending by opening up departments' plans to public scrutiny and making public tender opportunities more accessible to SMEs, individually or in consortia. The UK wants to create a more competitive and transparent procurement system which drives value for money for the taxpayer, and contributes to demand in low-carbon goods and services and capability and innovation in the private sector. This is unlocking barriers to SMEs, including a system to help SMEs find public sector procurement and subcontract opportunities online. Procurement is being used as a lever, through enabling a Small Business Research Initiative to support innovation in new technologies and to direct public money towards firms that are developing new and innovative technologies.

\section{d) Reasons for the success or failure of the approach}

Success will be determined by a combination of factors including resources and determination behind the initiatives and the ability of SMEs to respond to the opportunities created. The competitiveness of the tax system and specific innovation related incentives such as the R\&D tax credits play a valuable role in supporting innovation and productivity. The UK has set out a Road Map on plans for consulting on the support for innovation and it will be vital that such engagement listens then acts on SME concerns and suggestions.

One determinant will be the success of the support for innovation and the development of new products and processes. The Technology Strategy Board (TSB) was set up as the national agency responsible for stimulating and supporting technological business innovation. This aims to encourage new developments, learning through networks and innovation at all levels. It works with companies of all sizes, including entrepreneurial start-ups and family businesses, and runs a range of collaboration and financial support programmes. These programmes will assist businesses with new ideas and the development of new products and processes as well as create a national network of Technology and Innovation Centres (TICs) to help commercialise new and emerging technologies in areas where there are large global market opportunities.

By working with companies of all sizes, from entrepreneurial start-ups and new businesses to medium enterprises and major UK corporations, the TSB should spread ideas and attitudinal change that can positively influence SME behaviours for growth. Regional and local agencies will work with the TSB in a number of areas:

- Raising awareness and take-up of the funding and support programmes available for businesses in local communities, especially for new and early stage enterprises looking to develop and test their ideas or new technologies.

- Identifying opportunities where the Technology Strategy Board is investing in sectors and technologies of particular importance to a region. 
- Getting involved in major programmes being run and supported by the Technology Strategy Board in major fields such as sustainability, low carbon buildings and vehicles, healthcare and transport.

- Using the Technology Strategy Board's online networking portal to host local business groups and networks.

- Signposting businesses and other organisations to networks such as the Knowledge Transfer Networks which operate across a number of high-growth sectors and provide innovative businesses with free networking facilities and online tools.

- Using TSB programmes to help encourage and accelerate knowledge transfer between Higher Education Institutions and businesses which can have a major impact on local economic development.

\section{e) Obstacles faced in implementation and the quality of the response taken}

Major changes require a commitment to follow through with resources and generate successes to build confidence and develop a new market response. This is a work in progress as adjustments are made and it is especially challenging in times of economic crisis. Changing behaviours and culture always takes time and requires leadership and followership.

SME has a wide definition and it is often easier for medium sized businesses to respond to new initiatives and become attractive clients as they have some degree of critical mass to deliver economic benefits more quickly than small or micro businesses. In the area of innovation, there is the additional challenge of communicating to SMEs that the concept is relevant to all enterprises and extends beyond high profile scientific R\&D.

Intermediaries such as respected trade organisations and mentors have an important role in spreading the message and engaging with the SME community. Relationships also require to be nurtured and good practices illuminated through successful demonstration initiatives. This applies to SMEs and to higher education institutes in forming collaborative partnership to access funding or procurement opportunities.

\section{f) Considerations for successful adoption in the Lombardy region}

The alignment of resources and agencies locally is a major consideration. Lombardy has a number of organisations that contribute to the range of assistance available to SMEs and significant funding flows into developing the pillars of competitiveness. In order to adopt some of the specific ideas from the UK approach, some agencies would need to adjust their relationships and consider how to strengthen working links between sectors to promote cross sector innovation, sharing market knowledge and developing new capacity building initiatives. This could also stratify assistance and prioritise growth SMEs more openly.

\section{8) Innovation Norway}

\section{a) Description of the approach}

Innovation Norway is a governmental funded agency promoting industrial and regional development through contributing to innovation, internationalization and promotion. Services are provided through three strategic areas: innovation milieus, SME growth and entrepreneurship. The 
first area includes two cluster programmes relevant to promoting knowledge networks and innovation: Norwegian Centre of Expertise and Arena, a Business Network service and several other networkbased services. Innovation Norway has offices in all counties throughout Norway and in more than 30 countries worldwide.

It is a membership organisation open to organisations and individuals. Benefits to members include access to:

- Knowledge sources and information.

- Networking with different actors including potential international cooperation partners and contact points to exchange experiences and best practices in a dynamic regional dialogue.

- Global visibility through membership profile and showcase.

- Accreditation to use the logo and membership status.

The Arena programme has been run by Innovation Norway, SIVA and the Research Council of Norway. It targets the long term development of regional business clusters. The programme offers both advisory and financial support.

The objective is to strengthen the clusters innovative ability through a stronger and more dynamic interaction between the industry, $\mathrm{R} \& \mathrm{D}$ institutions, universities and the public sector. The interaction is to be long-term, goal-oriented and focused on innovative collaboration, international awareness, access to knowledge and new business.

Norwegian Centres of Expertise (NCE) is an ambitious venture which has produced a number of good results. The NCE is a clusters based approach to develop industry. It aims to speed up the productive process of creation in regional business environments, through cooperation between companies, researchers, colleagues and public authorities. In addition, they must be internationally oriented.

The NCE programme has a long-term perspective. The companies which are participating are offered professional and financial support for development processes for up to ten years.

Belonging to the NCE network is for most companies more about the collaboration and access to knowledge networks than money. It produces opportunities to cooperate, develop synergies, campaign for infrastructure investments, internationalisation, recruitment and increased competence and capacity building. It has also become a recognised brand with value through association that confers considerable status and pride. regions.

Specific initiatives such as the Business Garden have been developed for rural, remote parts of

Business garden aims to enhance entrepreneurship and new business development in remote areas without colleges or universities in Norway. A business garden is a physical space that locates knowledge-based companies in innovative networks. The aim of business garden is to stimulate innovation in SMEs and stimulate a process of creating successful enterprises in less developed areas. A business garden supports entrepreneurs and companies with:

- business experience; 
- knowledge;

- finance;

- networks (clusters).

\section{b) Rationale for the policy intervention}

Numerous special interest groups have been created to develop knowledge and potential collaboration opportunities. Also regional project networks have emerged to link with counterparts in other countries.

The network has gathered a wide range of members nationally and internationally and created a wealth of valuable information, contacts and projects. Many of these have emerged from local level and strengthened the regional economies where cluster development concepts have been applied.

An evaluation of the Business Garden concept underlined that the scheme had a significant effect in enhancing local business environments:

- Business gardens have contributed to strengthen and develop local business enterprises and local business investments as a part of a broader and long term local economic development.

- Job creation in companies within a business garden are more sustainable compared to other companies in the local economy, and contributes therefore to reduced "churn" in the local business community.

- Enterprises in business gardens can over some time contribute to an increased range of competence based jobs in the area.

- Job creation attracted more women entrepreneurs and employees as well as for young people.

Recommendations for further investments included:

- Strengthening of the intern network building in the business garden.

- Strengthening of the network building with the local business environment outside the business garden.

- Strengthening the environment for the female entrepreneur.

- Strengthening agencies networking role to increase synergies between business garden and companies through the country.

- Strengthening of the competitive ability of small stable companies as well as the growth oriented companies.

- Ensuring the further public support to mutual functions and development of the local environment.

- Sale of the services to local and regional business enterprises. 


\section{c) Strengths and weaknesses}

The government backing and consistent support has been a major strength together with access to global best practices and ideas on innovation practices as well as potential partners. This has all worked to develop bonds between members of the community and productive sub communities which have driven new initiatives that would not otherwise have happened.

As a membership organisation it does raise some revenues and does require certain adherence to formal rules and codes of conduct. This formality could be seen as a weakness but it is outweighed by the dynamism that is created by members forming organic alliances and short term associations as well as long term projects on occasions. This mix of formats works well.

Specific interventions such as Business gardens are integrated parts in the broader local strategic framework for development, and have a local multi-stakeholder approach. A successful business garden can give confidence and credibility as well as function as an attractive and transparent partner for multinational business and organizations.

The concept covers a range of local tailor-made concepts and tools for sustainable and competitive economic growth in areas with slow growth or specific economic challenges. They have worked to bring together information on established global models of enhancing economic growth and best practice from enhancing entrepreneurship and innovative businesses in areas where there is lack of companies, knowledge, capital, institutions and skills.

\section{d) Obstacles faced in implementation and the quality of the response taken}

Networks have become central to successful industrial policy implementation. However the practicalities are often challenging for various reasons.

Government agencies are often seen as cumbersome in the form of intervention and slow in effecting change. The networking approach required participants to engage and evolve the network to create a sustainable dynamic that would build and attract more participants, nationally and internationally. By encouraging this from the start and introducing international connections and showcase platforms, such as events and conferences, this was largely overcome.

Encouraging SMEs and other businesses to cooperate as well as compete is also a challenge. The benefits of doing so must be demonstrated and trust built over time with real business benefits emerging quickly. Successful networks show how it can be vital to cooperate in key areas such as international visibility and development of new technical solutions and platforms.

It is also important to establish industry-independent programmes for companies that truly want to gain advantages in networks. Such programmes require to offer professional and financial support in establishing networks. Results cannot be forced and require nurturing with consistency of support as regional culture change is promoted.

\section{e) Considerations for successful adoption in the Lombardy region}

The initiatives have been in line with the policy objective of developing local and regional business environments and systems that improve the prerequisites for added value based on innovation. The transferability of such initiatives to be implemented successfully in other locations such as Lombardy, would require specific customisation to suit the regional challenges. It also bundles a number of sector interests including tourism which has many advantages in promoting innovation in 
such sectors. This could be valuable in Lombardy to spread the innovation message beyond traditional design businesses and development of high value service sectors.

\section{f) Information}

Innovation Norway

P.O. Box 448 Sentrum

NO-0104 Oslo

Norway

Tel.: +4722002500

\section{Access to Finance}

\section{9) Contrat de Développement Participatif, OSEO, France}

\section{a) Description of the approach}

In 2009, OSEO, the French publicly owned entity that is responsible for facilitating access of SMEs to long-term capital, has launched the Contrat de Développement Participatif (CDP). This financial instrument is a response to the growing difficulties of French medium-sized firms in obtaining market-based financing. Its development is thus consistent with OSEO's basic mission, which is to support SMEs' access to riskier forms of financing that may allow them to grow or develop innovative projects.

Typically, OSEO's products and services target critical stages in the life of the company, such as the founding, the expansion, the transmission (change of ownership or control) and the internationalisation. OSEO's offer responds to a perceived imbalance between the kinds of finance that SMEs are seeking and the kinds that the market is willing to offer. Many SMEs that have the opportunity or the necessity of making basic transitions, hesitate to rely solely on external equity, which would lead to dilution of ownership and control of the firm. According to OSEO, only about one fourth of French SMEs, of which a large share is closely associated with their founding entrepreneurs and/or is family owned, would be open to enlarged equity participation by outside investors. Furthermore, the returns on many operations are not high enough to qualify for equity finance.

The CDP is directed to firms that are more than three year old and have less than 5000 employees. It supports investment programmes by providing mezzanine finance, that is, financial instruments that combine debt and equity characteristics. More in detail, the CDP consists of a subordinated loan of seven-year maturity with two years grace (i.e. no principal repayments are made for the first two years.). The interest rate may be fixed or variable and is set according to the risk rating assigned by the Banque de France. OSEO receives additional compensation in the form of a share (usually about 5\%) of the increase in firm turnover following the loan. OSEO's risk is limited by a public guarantee fund which covers $80 \%$ of the risk, plus a $5 \%$ deposit by the company.

Eligibility criteria include co-financing by a bank and the entrepreneurs themselves. In fact, OSEO participates in operations for which support by a bank is also provided. The bank loan covers capital goods and material purchases while the CDP can be used to cover intangible expenses such as outlays to meet environmental norms, for acquisition of other companies, IT expenses, training and recruitment of personnel, foreign expansion, advertising and marketing. In addition, the contribution by OSEO is limited by the capital contribution of the shareholders. A further requirement is that the 
firm must obtain bank funding that is at least twice as large as the OSEO contribution loan or an increase in equity (from existing or new shareholders) of an amount at least equal to the OSEO contribution. In some cases, an additional requirement for approval is an insurance policy covering key owners or executives be purchased. In cases where the CDP is accompanied by a bank loan, OSEO can provide a guarantee of up to 70\% for the loan, from OSEO's own guarantee funds or from a regional guarantee fund. In any case, the size of the CDP is limited as a multiple of the shareholders equity and can range from EUR 300000 to EUR 3 million.

From December 2009 to December 2011, EUR 1.1 billion have been granted under the scheme to 1076 firms, allowing them to raise EUR 5.5 billion of investment funding from other sources. About $76 \%$ of CDPs have been to firms with 249 or fewer employees. About $80 \%$ of the firms involved have been in industry, services and trade. Most industrial companies are involved in manufacturing intermediate goods while many service-oriented firms are in the category of business services rather than consumer services. Also, the firms that utilise DCs are older and more concentrated in traditional activities rather than high technology sectors. However, about $44 \%$ of enterprises are characterised as being in a process of innovation and $36 \%$ of enterprises are characterised as significant exporters, with foreign sales accounting for at least $5 \%$ of total sales.

\section{b) Relevance to Lombardy}

The CDP represents a potentially useful addition to the range of finance vehicles available to SMEs, which, in Lombardy, as in Italy, are rather narrow, especially for growth-oriented and innovative SMEs. Mezzanine-like instruments, like the CDP, can help to fill the existing gap in growth capital, which limits the capacity of many firms in Lombardy to expand. In fact, mezzanine capital is typically addressed to firms that have attained profitability, have a rather stable cash flow and moderate growth profile, but cannot easily access the equity capital that would support their expansion or are not willing to relinquish control to equity investor. This is often the case of family-owned SMEs, a feature of Lombardy's business landscape. Mezzanine finance can also enable firms to reduce their over-reliance on debt, improving their financial structure.

With regard to the implementation of the programme, it is relevant to note that OSEO has a strong regional focus and operates in close relationship with local governments, chambers of commerce, industry and professional associations, financial institutions, mutual guarantee societies, venture capitalists and business angel networks. Some 1000 of its 1700 employees work outside headquarters in regional offices. Therefore, the implementation of these programmes is largely carried out at the regional level and implies close coordination with local institutions.

\section{c) Considerations for adoption}

The development of mezzanine finance vehicles requires specific competences on both the supply and the demand side. Mezzanine investment takes place only in the private market and usually through a limited investment partnership in which professional managers are the general partners (GPs) who contribute expertise in the management of mezzanine investment, while the limited partners (LPs) are entities with funds to invest. Funds may also be provided by official entities who may award investment mandates to commercial mezzanine specialists under the assumption that private investment specialists are better able than public officials to identify promising candidates for mezzanine finance and to interact with such companies at varying stages of their growth cycle. Also in the case the fund is directly managed by the public entity, specific expertises are required. On the side of the demand, diffusion of these instruments may be limited by the lack of awareness and understanding of entrepreneurs. Also in their case, update of competencies in financial matters appear to be a pre-requisite for accessing non traditional finance vehicles. 


\section{d) Information}

OSEO

27-31, avenue du Général Leclerc

94710 Maisons-Alfort Cedex

Web:www.oseo.fr/oseo_investissements_d_avenir/financement_des_entreprises/contrat_de_developpe ment_participatif

\section{0) High-Tech Gründerfonds Gmbh, Germany}

\section{a) Description of the approach}

The High-Tech Gründerfonds is a German public/private partnership aimed at funding young, high potential, high-tech start-ups, enabling them to get innovative ideas to the market. The main target group are spin-offs from public research institutions and universities as well as corporate spinoffs. The proposals submitted by single researchers are evaluated by a project management and technology-specific steering committees. Three such steering committees exist: Software/information technologies, Life Sciences/New Materials, Telecommunication and Media.

The seed financing provided is designed to enable start-ups to take an idea through prototyping and to market launch. Typically, the fund invests EUR 500000 in the seed stage, with the potential for up to a total of EUR 2 million per portfolio company in follow-on financing. Funding is delivered through a combination of equity investment and second-tier loan. In the first years, enterprises are lifted from interest payment. Equity capital from the founders is required in the amount of $20 \%(10 \%$ in the Eastern federal states, including Berlin) in relation to the holdings of the fund. Half of this amount can be represented through other seed investors (side-investment).

The High-Tech Gründerfonds team of investment managers offers the new start-ups valuable support on a partnership basis. It works with a pool of experienced experts, from which the founders can select their special coach. Coaching usually starts during the development stage of the business idea and ends when follow-up financing has been achieved, or once the enterprise has achieved sustainable, self-financing from cash flow.

The programme started in 2005 with a first endowment of EUR 272 million (HTGF I). The second fund (HTGF II) was introduced in October 2011 with an additional investment volume of EUR 291 million. The partnership includes the Federal Ministry of Economics and Technology, the KfW Banking Group, as well as thirteen industrial groups, such as ALTANA, BASF, B. Braun, Robert Bosch, CEWE Color, Daimler, Deutsche Post DHL, Deutsche Telekom, Evonik, Qiagen, RWE Innogy, Tengelmann and Carl Zeiss. The engagement of these groups is based on the idea that the lack of early-stage finance for young start-ups also constitutes a problem for the industry, because it curtails the development of innovative technologies that may at a later time constitute an essential source of innovation in their fields.

As of 30 June 2010, more than 190 equity participations and more than 156 follow-up financings (i.e. additional financing rounds for already supported enterprises) had been completed, with a total volume of EUR 220 million. 


\section{b) Relevance to Lombardy}

The region is characterised by a highly diversified business sector, in terms of industries, stages of production, as well as firm size. Together with a large population of highly specialised SMEs, important multinational industry groups have their seat in Lombardy. However, interviews with policy makers and stakeholders reveal that these large industry players are not commonly engaged in the funding, design and implementation of publicly-support programmes targeted to innovative SMEs. The German experience shows that these groups may have an interest in cooperating with the public sector to encourage innovation-based entrepreneurship, increase R\&D orientation by SMEs, improve the overall competitiveness of small businesses, and scout for talents and ideas in a more innovative environment.

\section{c) Considerations for adoption}

In Germany, the development of the programme builds on the long-term collaborative relationship between policy makers and industry leaders. The programme in fact benefits from their financial contribution, but also from their expertise and possibly scouting of most promising novelties. Coaching is an essential part of the programme. It is therefore necessary that, given the main areas of focus, these experts are identified and linked with the would-be entrepreneurs. An important role is also played by the technology-specific steering committees, which examine the applications and select the projects. The selection process for interested high-tech enterprises is however based on common Venture Capital practices.

A highly important quality aspect for High-Tech Gründerfonds and the potential of the companies in its portfolio is the amount of capital flowing into these companies from other investors. In this regard, for the scheme to be effective, a favourable environment for investment in high tech ventures and interested parties are of the essence.

\section{d) Information}

High-Tech Gründerfonds Management GmbH

Dr.Martin Pfister

Investment Manager

Ludwig-Erhard-Allee 2

53175 Bonn

Tel.: +49 $228823001-00$

Fax: +49 $228823000-50$

E-mail: info@high-tech-gruenderfonds.de

Web: www.high-tech-gruenderfonds.de

\section{1) The Ready2Invest Programme, London, UK}

\section{a) Description of the approach}

This programme has operated in the London region since 2004 and is funded by the London Development Agency. However, the potential angels participating in the programme have been drawn from the wider south-east region of England and do not confine their investing activities just to the London area. The objective of the programme has been to increase the pool of business angel investors and thereby boost the supply of equity to small firms. This means recruiting high net worth individuals with relevant business experience and an interest in helping to build, support, mentor and invest in 
early-stage companies with growth potential. The programme was developed because it became clear from information supplied by intermediary firms that many potential angels were reluctant to get involved partly due to lack of knowledge about what being a business angel entails, as well as lack of relationships with existing investors. This even applied to people with much commercial and industrial experience, but who did not have knowledge on small business investment. The programme was also considered necessary to maintain the capacity of existing networks. Business angels often have a limited amount of money to invest and once these funds have been placed, they drop out of active investing. The programme was finally conceived to attract "knowledge angels" to pass on relevant processional and business experience to investee companies, without necessarily investing themselves, or perhaps only making a small investment. Knowledge angels should not be confused with consultants who may work for a fee, as their contribution will always be made in return for equity in the investee company.

Subsidiary objectives of the programme have been to: (i) improve the effectiveness of angels investing through the training provided; (ii) boost investment deal flow from the networks of new investors recruited through the programme; and (iii) increase general awareness of business angel investing through the marketing of the programme.

The programme is offered for a minimal charge to participants, although membership of a business angel network in the UK will normally require a substantial fee, sufficient to indicate the seriousness of the member to engage in investment activity. Participants are generally introduced by accounting firms which may also be active in the programme, either through sponsorship or involvement in workshops, or both. Participants will usually be the clients of those firms. Marketing materials and finance are available under the programme to promote awareness amongst target groups.

At the heart of the programme is a rolling series of workshops which include presentations of experienced investor concentrating on actual case studies, an introduction to small business investment skills, a guide to methods of syndication and co-investment, and presentations of the tax and legal issues in becoming a business angel. In addition to the workshops there are round table discussions with investors. Participants can attend as observers business angel network presentation events. An on line self assessment diagnostic tool and a specially produced angel investment manual help participants to test their suitability to be a business angel in privacy, and educates at the same time them as to the process and risks.

The outcomes of the programme so far are:

- 350 people attended workshops;

- $58 \%$ joined an angel network or group;

- $70 \%$ of these have made investments so far;

- $30 \%$ have invested as part of a syndicate;

- $75 \%$ intend to make future investments;

- $70 \%$ of all participants had recommended the programme to others.

\section{b) Relevance to Lombardy}

Business angel networks are particularly relevant for those regions endowed with a base of potentially growth-oriented businesses which may be interested in equity investments. Although much of the attention in the equity finance literature is on venture capital funds, mainly because of wellknown success stories, business angels raise globally a much larger amount of equity capital than do venture funds. Most importantly, they are a powerful tool of local economic development thanks to 
some inherent features. In particular, business angels often become a source of further networks for the investee enterprise. For instance, they may link up the invested company to additional legal and business sources of advice, as well as introduce the company to other larger sources of equity finance (e.g. venture capital). As compared to venture capital funds, business angel networks also normally allow for a longer investment horizon and exert a lower level of control on the management of the invested company, both of which represent a plus and may convince small business owners to relinquish partial control on management decision.

\section{c) Considerations for adoption}

In the UK, the success of the "Ready2Invest" programme relates to its linkages with an established business angel network, involving members directly in bringing on the new, potential angels. The support of financial intermediaries in identifying candidates, providing sponsorship and participating in the training was also important. Above all, the financing from the London Development Agency based on a strategic awareness of the importance of boosting angel activity was critical.

The adoption of a similar approach in Lombardy would need to take into account two specific characteristics of the local financial environment. First, the base to start with - the business angel network - is less developed than in the UK context. This implies that, in the first stages, a greater effort would be needed by the public institution (or its partners) to identify potential investors and link them up. Second, the local SME sector is less familiar with equity investors and often concerned by operations that might imply relinquishing the business control. Small business owners are naturally averse to sharing ownership and management decisions and so possibly sceptical towards the whole concept of equity finance. The policy maker should also consider that there are information barriers to overcome on the supply side of the equity market, as potential investors may not be aware of current local investment opportunities or simply do not know what being a business angel implies. Initial awareness-raising campaigns addressing both sides of the equation may pave the way to the adoption of a programme such as "Ready2Invest".

\section{d) Information}

Ready2invest Ltd.

Olivier House,

18 Marine Parade,

Brighton,

BN2 1TL

E-mail: talk@ ready2invest.co.uk

Web: www.ready2invest.co.uk 


\section{ANNEX II: \\ The OECD Review Team Members}

Neil MacCallum is an economic development specialist with over 20 years experience of strategy appraisal, development and evaluation working with national and regional development agencies, the UK National Audit Office, the EU, World Bank, ILO and OECD. He has managed many projects and strategy development studies at local, regional and national level and assisted in the development of new approaches to assessing economic impact. Neil was A Senior Manager in the Strategy Directorate and Head of Appraisal and Evaluation at Scottish Enterprise for over ten years. $\mathrm{He}$ is a Senior Expert Advisor to the OECD on appraisal, evaluation, performance measurement, regional development and impact assessment and has participated in many EU studies and expert groups. In the UK, he has worked with regional and local enterprise agencies in the assessment of market failure responses, preparation of strategies in various sectors including tourism, preparation of market appraisals and approval papers, generation of impact assessment evidence and developed evaluation frameworks which shaped the development of similar frameworks in other agencies around Europe. This led to work with OffPAT, the Office for Project Advice and Training in London, where he assisted in the development of the revised project and programme appraisal guidance. This work involved liaison and detailed discussion with UK Government Departments, in particular with HM Treasury and Department for Trade and Industry, on evaluation of sectors and specific regeneration project appraisals.

Lucia Cusmano is Senior Economist at the OECD Centre for Entrepreneurship, Small and Medium-sized Enterprises (SMEs) \& Local Development (CFE) and Executive Secretary for the OECD Working Party on SMEs and Entrepreneurship (WPSMEE). Ms Cusmano has a PhD in Economics from the University of Pavia (Italy) and has completed a Master of Science in Economics at Warwick University (UK). She has published extensively in international journals on SMEs, entrepreneurship, innovation, structural change, institutions and economic development in advanced and developing regions. Ms Cusmano holds the position of Assistant Professor of Political Economy at Insubria University, Varese (Italy) and Research Fellow at KITES (Knowledge, Innovation and Technology Studies), Bocconi University, Milan (Italy).

Ricardo Pinto gained his PhD from the London School of Economics (LSE), where he studied and subsequently worked at the Centre for Economic Performance (CEP). He has experience of working for university (LSE), local government (London Borough of Hackney), international organisations (OECD) and consultancy (GHK International, GEWOS, Pinto Consulting, etc.) He has 15 years of international consultancy experience based on assignments in ca. 30 countries in EU, Central, Eastern and South Eastern European, as well as African and Central Asian transition economies. Dr. Pinto has worked on various aspects of entrepreneurship and enterprise development. $\mathrm{He}$ has established an international consultancy (www.pintoconsulting.de) and has undertaken assignments on behalf of international organisations such as EC, DFID, UNDP, EBRD and OECD. His work typically focuses on private sector development (economic development, SME development, start-ups, informal economy, competitiveness, innovation, etc.), regional development, public-private dialogue, etc. He has experience of policy analysis, as well as designing and implemented projects. Ricardo is a Certified Management Consultant (CMC) and a member of various bodies such as the 
OECD LEED Trento Centre "Scientific Advisory Group on Entrepreneurship"; Local Economy Editorial Board; and Management Consultants' Association 2000.

Alessandra Proto is Policy Analyst at the OECD LEED Trento Centre for Local Development based in Italy, where she has been working since its establishment in 2004. She manages the activities related to entrepreneurship, innovation, SME and tourism in OECD member and non-member economies. She contributes to the development of a number of OECD LEED projects, particularly with regard to the management of country reviews on SME development, entrepreneurship, innovation and tourism. She is in charge of the design and implementation of the capacity building activities of the Trento Centre and of the OECD Summer School for Community and Local Development, where she works with policy makers and practitioners working in the field of local economic and employment development, in both OECD member and non-member countries, to formulate and evaluate policy options and modes of implementation based on an understanding of the needs, potential and limitations that exist within a locality. Alessandra Proto obtained her degree in Economics and Management of Public Administration and International Institutions from the Bocconi University in Milan.

Paolo Rosso is a senior expert advisor to OECD. He holds a degree in engineering from the University of Trieste. Since 1990, he has been working on economic and territorial development projects, and policies and programmes for integrated economic development and SME support. Paolo Rosso has professional experience in Italy, other European countries (Bulgaria, Bosnia and Herzegovina, Czech Republic, Slovak Republic, Croatia, Slovenia, Hungary, Romania, Russia, and Turkey), and Latin America (Argentina, Uruguay, Brazil, Venezuela, and Mexico). He currently works as a consultant for international corporations, governmental and international institutions (ministries, local administrations, the European commission, governmental and development agencies in Italy and abroad). Further collaborations include those with the IADB (Inter-American Development Bank of Washington DC), OECD (Organisation for Economic Co-operation and Development) and ERVET (Regional Development Agency of Emilia-Romagna Region of Bologna, Italy), where he worked in the early 1990s within the Regional Planning Unit. Between 1994 and 1995, he was director of CHEMIO SRL, an enterprise specialising in environmental and energy services for SMEs in North East Italy. Since 1996, he has been working as an independent consultant. Paolo Rosso's main expertise lies in the following areas: Regional and local economic development projects and public investment programmes in Italy, Europe and Latin America; planning, monitoring and evaluation of European Structural Funds for Cohesion and Development Policies of the European Commission; design and implementation of services for SMEs, development of productive districts, management of projects for modernisation and innovation of development policies and public administration at regional and local level, and socio-economic analysis and urban/territorial planning 




\section{Boosting Local Entrepreneurship and Enterprise Creation in Lombardy Region}

